UNIVERSIDADE DE BRASÍLIA

INSTITUTO DE CIÊNCIAS SOCIAIS

DEPARTAMENTO DE SOCIOLOGIA

\title{
MENSALISTAS E DIARISTAS: \\ AS IMPLICAÇÕES PERTINENTES ÀS RELAÇÕES ENTRE FAMÍLIAS, RENDIMENTO E DIREITOS DE TRABALHADORAS DOMÉSTICAS
}

Autor: Paulo Donisete Bento 
UNIVERSIDADE DE BRASÍLIA

INSTITUTO DE CIÊNCIAS SOCIAIS

DEPARTAMENTO DE SOCIOLOGIA

\section{MENSALISTAS E DIARISTAS: AS IMPLICAÇÕES PERTINENTES ÀS RELAÇÕES ENTRE FAMÍLIAS, RENDIMENTO E DIREITOS DE TRABALHADORAS DOMÉSTICAS}

Autor: Paulo Donisete Bento

Dissertação apresentada ao Programa de PósGraduação do Departamento de Sociologia da Universidade de Brasília - PPGSOL/UnB como parte dos requisitos para a obtenção do título de Mestre.

Brasília, 30 de setembro de 2016. 
UNIVERSIDADE DE BRASÍLIA

INSTITUTO DE CIÊNCIAS SOCIAIS

DEPARTAMENTO DE SOCIOLOGIA

PROGRAMA DE PÓS-GRADUAÇÃO EM CIÊNCIAS SOCIAIS

DISSERTAĊ̃̃O DE MESTRADO

\section{MENSALISTAS E DIARISTAS: \\ AS IMPLICAÇÕES PERTINENTES ÀS RELAÇÕES \\ ENTRE FAMÍLIAS, RENDIMENTO E DIREITOS DE TRABALHADORAS DOMÉSTICAS}

Autor: Paulo Donisete Bento

Orientador: Joaze Bernardino-Costa

Banca Examinadora:

Professor Joaze Bernardino-Costa - presidente da banca (ICS - UnB)

Doutora Ana Cláudia Jaquetto Pereira

(IESP - UERJ)

Professora Tânia Mara Campos de Almeida (ICS - UnB)

Professora Soraya Resende Fleischer - suplente (ICS - UnB) 


\section{AGRADECIMENTOS}

Agradeço à CAPES - Comissão de Aperfeiçoamento do Pessoal do Nível Superior - e ao programa ProMD/UnB/FAPDF - Programa de Bolsas de Mestrado e Doutorado da Universidade de Brasília e Fundação de Apoio à Pesquisa do Distrito Federal - pela bolsa concedida que tornou possível essa pesquisa.

Agradeço a meu orientador, Joaze, pelo apoio e imensa compreensão nesse percurso. À prof. ${ }^{a}$ Tânia Mara e a Dr. ${ }^{a}$ Ana Cláudia por terem aceitado participar da minha banca de defesa, e a prof. ${ }^{a}$ Renísia que esteve na de qualificação. Obrigado pelas imensas contribuições dadas, em especial ao Joaze e a Tânia que mudaram irreversivelmente a minha posição e perspectiva no mundo.

Às professoras e aos professores do Departamento de Sociologia que participaram da minha formação Artur Trindade, Christiane Nunes, Lourdes Bandeira e Sérgio Tavolaro. Não posso deixar de mencionar especialmente Fabrício Neves que além de professor, tem feito um ótimo trabalho à frente da Pós-Graduação de Sociologia e é a quem recorremos sempre que precisamos de ajuda.

Ao pessoal da secretaria, Ana Paula, Gabriela, Leonardo e Patrícia, sempre muito solícitos.

Às caríssimas Ângela, Antônia, Cecília, Celina, Cleide, Érica, Flávia e Zélia, que foram parceiras nessa pesquisa. Obrigado por terem dividido parte das suas vidas comigo, pelos cafés, por aquele folheado doce que eu nunca vi gostoso igual, pelo queijo (me criei em Minas, então, café com queijo sempre derretem meu coração).

Agradeço também a Simão pelas ótimas histórias das suas viagens e pela amizade. Sempre conversávamos como amigos pessoais, nunca foi intensão trazer suas histórias para dentro da pesquisa, mas diante de alguns diálogos com outras trajetórias, foi inevitável.

Julio, Guto, Eder, se não fosse vocês, eu não estaria aqui. Gratidão!

Às queridas Carmem, Jéssica e Maria Clara. À minha mãe, que sempre tem me dado força para continuar e que sempre me leva a pensar duas vezes no que quer que eu escreva. 


\section{RESUMO}

Duas mudanças paradigmáticas concomitantes atingiram o trabalho doméstico a partir dos anos 2000: a aquisição paulatina de direitos por mensalistas com a efetivação crescente deles e o aumento da proporção do trabalho doméstico executado por diaristas no serviço doméstico remunerado. Essa última modalidade não tem qualquer direito, razão pela qual a diarização do trabalho doméstico é apresentada como válvula de escape que ameaça a efetivação de direitos adquiridos. Em oposição a isso, rendimento maior e a contribuição previdenciária que cresce a um ritmo mais intenso entre diaristas têm se afigurado como critérios usados para questionar a noção de que a diarização do trabalho doméstico equivale a sua precarização. Nessa medida, a responsabilidade por "aproveitar" as possibilidades abertas pela diarização recai sobre as trabalhadoras, ressuscitando uma noção de tradicionalismo que remete à literatura sociológica clássica. Nesse quadro, baseado em entrevistas de oito trabalhadoras domésticas e em de dados coletados da PNAD, esta dissertação analisa relações sobre quatro elementos que orbitaram as narrativas fornecidas pelas entrevistadas: a família empregadora, a própria família da trabalhadora, além dos anteriormente citados rendimento e direitos (materializados na carteira de trabalho assinada ou na adesão à condição de contribuinte previdenciária autônoma). Desse modo se perceberá que as experiências das trabalhadoras são centrais para se perceber e ultrapassar as lacunas deixadas por aqueles critérios iniciais. As experiências das próprias trabalhadoras permitem perceber como e a que custo obtém rendimento melhor, nos casos em que o obtém, e os problemas relacionados à adesão por parte da trabalhadora à condição de contribuintes previdenciárias. A importância dessa investigação reside no fato de que, posto que o trabalho doméstico se situa no entroncamento de articulações de raça, gênero e classe social que formam a matriz da desigualdade no país, a aquisição de direitos aponta, em princípio, para o fim de uma era em que a ocupação era vista como resquício da escravidão. Portanto, analisar suas transformações se faz necessário para averiguar os impactos delas sobre conquistas de uma luta que já dura mais de oitenta anos. 


\begin{abstract}
Two concomitant paradigmatic changes reached domestic work from the 2000s: the gradual acquisition of rights by monthly workers with their increasing effectiveness and the increase in the proportion of domestic work performed by day laborers in paid domestic service. This last modality has no right, reason why the diarization of domestic work is presented as an escape valve that threatens the realization of acquired rights. In opposition to this, higher income and the social security contribution that grows at a more intense pace among day laborers have appeared as criteria used to question the notion that the diarization of domestic work amounts to its precariousation. To this extent, the responsibility to "take advantage" of the possibilities opened by diarization rests with the workers, resuscitating a notion of traditionalism that refers to the classical sociological literature. Based on interviews with eight domestic workers and data collected from PNAD, this dissertation analyzes relationships that relate to four elements that orbited the narratives provided by the interviewees: the family of the employer, the worker's own family, above mentioned income and rights (materialized in the work signed or in the adhesion to the condition of autonomous social security taxpayer). In this way it will be realized that the experiences of the workers are central to perceive and overcome the gaps left by those initial criteria. The experiences of the workers themselves make it possible to perceive how and at what cost they obtain better income, in the cases in which they obtain it, and the problems related to the worker's adherence social security taxpayers. The importance of this research lies in the fact that, since domestic work is located at the crossroads of race, gender and social class articulations that form the matrix of inequality in the country, the acquisition of rights points, in principle, towards the end of an era in which occupation was seen as a remnant of slavery. Therefore, analyzing their transformations is necessary to ascertain their impacts on the achievements of a struggle that already lasts more than eighty years.
\end{abstract}




\section{LISTA DE ILUSTRAÇÕES}

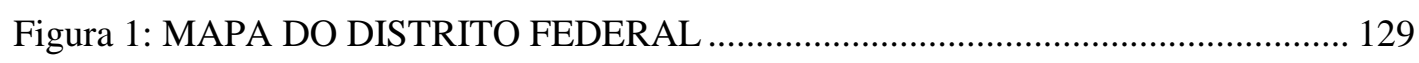

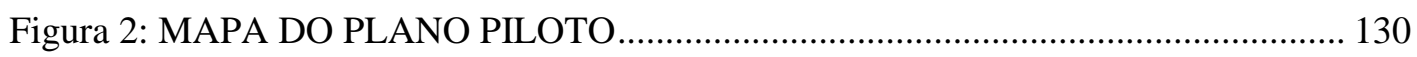

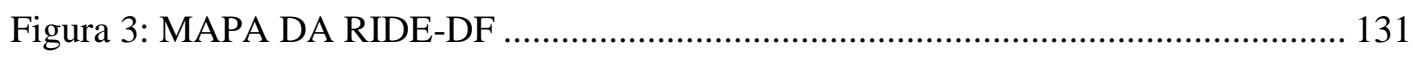




\section{LISTA DE TABELAS}

Tabela 1: VARIAÇÃO DO PERCENTUAL DE TRABALHADORAS DOMÉSTICAS DIARISTAS ENTRE 2002-2014 (EM \%) - BRASIL

Tabela 2: DISTRIBUIÇÃO RACIAL DE MULHERES NO INTERIOR DE GRUPAMENTOS OCUPACIONAIS (EM \%) - BRASIL

Tabela 3: PESO DOS GRUPAMENTOS OCUPACIONAIS NA DISTRIBUIÇÃO RACIAL DE MULHERES NO MERCADO DE TRABALHO (EM\%) - BRASIL 35

Tabela 4: NÍVEL DE INSTRUÇÃO FORMAL DE TRABALHADORAS NO MERCADO DE TRABALHO (EM \%) - BRASIL 78

Tabela 5: VARIAÇÃO DA ESCOLARIDADE DE TRABALHADORAS DOMÉSTICAS ENTRE 2002 E 2014 (EM \%) - BRASIL 79

Tabela 6: TAXA DE MIGRAÇÃO DE TRABALHADORAS DOMÉSTICAS DE ACORDO COM O ESTADO DE RESIDÊNCIA - BRASIL

Tabela 7: ESTADOS QUE APRESENTAM MÉDIA DE RENDIMENTO DE DIARISTAS E MENSALISTAS SUPERIOR À NACIONAL OU SUPERIOR AO SALÁRIO MÍNIMO (EM R\$) - BRASIL

Tabela 8: VARIAÇÃO DA IDADE DAS TRABALHADORAS DOMÉSTICAS ENTRE 2002 E 2014 (EM \%) - BRASIL 85

Tabela 10: PERCENTUAL DE DIARISTAS E MENSALISTAS DE ACORDO COM AS HORAS TRABALHADAS EM TODOS OS TRABALHOS DA SEMANA (EM \%) - BRASIL105

Tabela 11: NÚMERO MÉDIO DE HORAS SEMANALMENTE DISPENSADAS POR TRABALHADORAS NO SERVIÇO DOMÉSTICO NÃO REMUNERADO - BRASIL 106 


\section{ÍNDICE DE QUADROS}

Quadro 1: DIREITOS ASSEGURADOS PELA CONSTITUIÇÃO DE 1988 PARA O

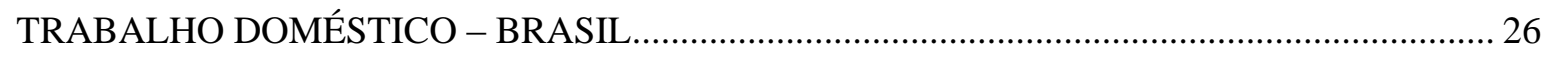

Quadro 2: MUDANÇA CONSTITUCIONAL DE DIREITOS PERTINENTES AO SOBRE TRABALHO DOMÉSTICO 29

Quadro 3: ENCARGOS PATRONAIS E EMPREGATÍCIOS A SEREM PAGOS POR EMPREGADORES DE TRABALHADORAS DOMÉSTICAS.. 30

Quadro 4: TRABALHADORAS DOMÉSTICAS ENTREVISTADAS ............................. 43

Quadro 5: REGIÕES ADMINISTRATIVAS DO DISTRITO FEDERAL ...................... 129 


\section{SUMÁRIO}

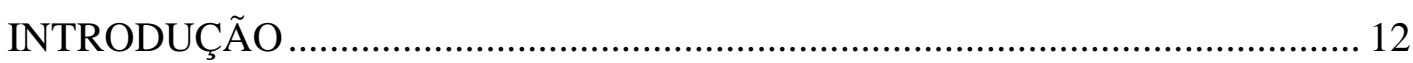

Diaristas e mensalistas no trabalho doméstico.................................................. 12

Descaminhos da definição de trabalho doméstico .............................................. 13

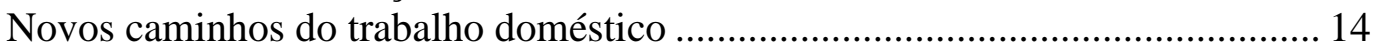

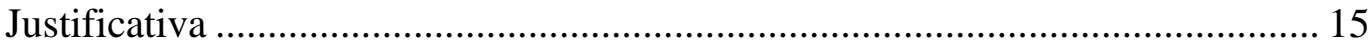

Aspectos metodológicos e capítulos ................................................................. 17

1 TRABALHO DOMÉSTICO: RAÇA, GÊNERO E DIREITOS ....................... 20

1.1 Direitos de trabalhadoras domésticas ontem e hoje ................................. 20

1.2 Trabalho doméstico e relações de interseccionalidade ............................. 33

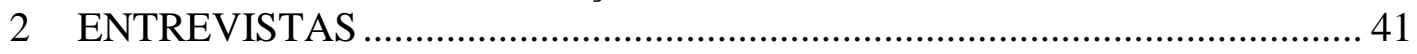

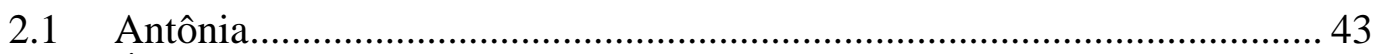

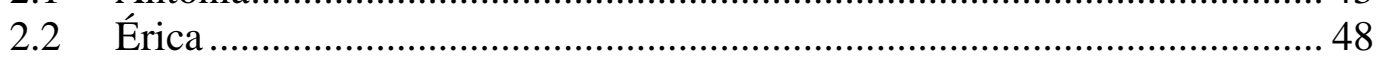

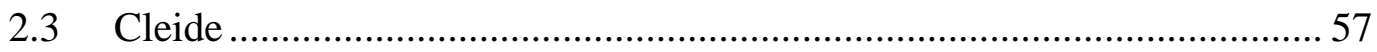

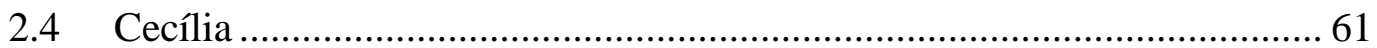

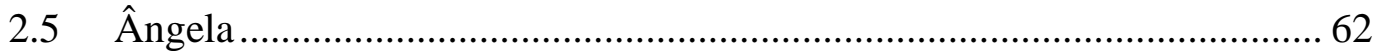

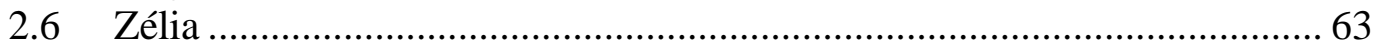

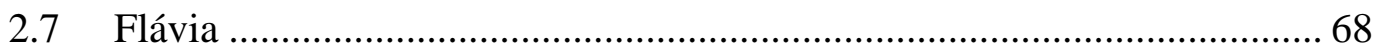

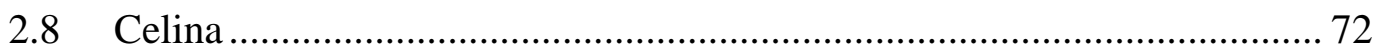

3 TRABALHO DOMÉSTICO MENSAL: CRIANDO SENSIBILIDADES ...... 76

3.1 Migração: faces da busca por melhores condições de vida ....................... 76

3.2 Migração: libertação ou prisão? ............................................................. 86

3.3 Trabalho afetivo e ambiguidade afetiva................................................. 89

3.4 O trabalho de diarista: especialização, organização das tarefas e emergências 97

3.5 Afetividade no trabalho de diarista ........................................................ 108

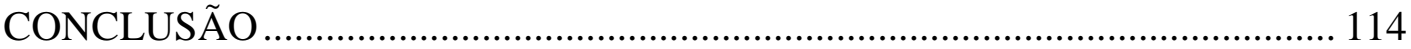

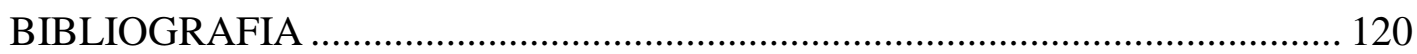

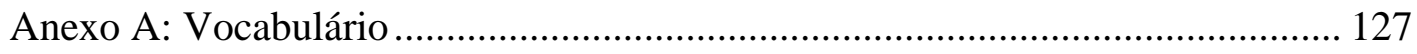

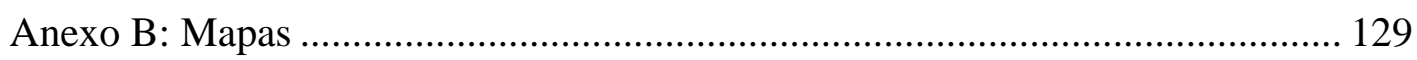

Regiões Administrativas (RA) de Brasília ..................................................... 129

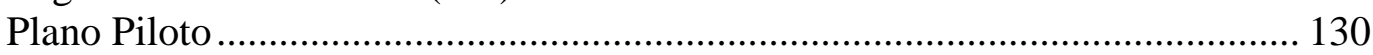

Região Integrada de Desenvolvimento Econômico do Distrito Federal e Entorno 131

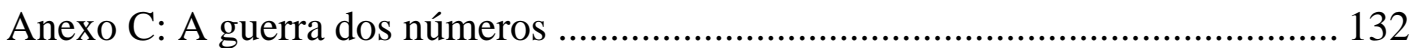




\section{INTRODUÇÃO}

\section{DIARISTAS E MENSALISTAS NO TRABALHO DOMÉSTICO}

Dizer "trabalhadora doméstica mensalista", frequentemente chamada de "empregada doméstica", não é tão preciso quanto a referência "cozinheira" ou "faxineira". É comum encontrar na mídia ou em jornais, quando se procura por "empregadas domésticas", as especificações: cozinhar, lavar, passar e cuidar da casa. Poucos empregadores hoje em dia buscam por mulheres que também durmam no trabalho. O número de mensalistas que se dispõem a isso diminuiu muito dada a exigência desse trabalho por disponibilidade em tempo integral.

"Empregada" ou "empregada doméstica" são categorias êmicas usualmente utilizadas para se referirem à mensalista. Tais categorias são preteridas por organizações sindicais e pesquisadores envolvidos com a questão. Nem sempre, no decorrer da pesquisa, tive sucesso no diálogo com entrevistadas ou em conversas com pessoas exteriores à pesquisa e ao campo das ciências sociais utilizando a categoria ética "trabalhadoras domésticas mensalistas". No entanto, esta última é a usada para pleitear o reconhecimento da ocupação como trabalho que deve ter direitos como os demais.

Quanto às diaristas, é comum que se refiram ao próprio trabalho como faxina ou limpeza sem pretender algum rigor na descrição. Quando se pergunta, no entanto, se elas passam roupa ou cozinham, não raro a resposta é positiva. Existem ainda diaristas que se especializam em uma única tarefa e a realizam em todas as casas onde trabalham; existem as que executam uma tarefa específica em alguma casa, mas não em outra e existe ainda as que executam funções específicas em todas as casas, embora não seja a mesma em todas elas: faxinam em uma, passam roupa em outra.... Assim, a tendência a se associar a diarista a funções específicas e a mensalista a funções generalistas, deve levar em conta que esses são casos extremos entre os quais existem muitas variações. 


\section{DESCAMINHOS DA DEFINIÇÃO DE TRABALHO DOMÉSTICO}

Apesar do percentual alto de trabalhadoras sem registro, $69,75 \%{ }^{1}$, esse índice, grosso modo, vem caindo ${ }^{2}$. Dentre as registradas $87,25 \%$ trabalham em uma única residência. Dentre as sem registro, $60,83 \%$ prestam serviço em apenas uma residência ${ }^{3}$.

O alto índice de diaristas sem registro se deve, em parte, à própria legislação. A Lei Complementar 150, de $1^{\circ}$ de junho de 2015 (LC 150/2015) ${ }^{4}$, denomina empregado doméstico "aquele que presta serviços de forma contínua, subordinada, onerosa e pessoal e de finalidade não lucrativa à pessoa ou à família, no âmbito residencial destas, por mais de dois dias por semana". Assim sendo, embora o trabalho de diarista também seja um trabalho doméstico e possa ter a característica da não eventualidade, não conta com a característica da continuidade.

Continuidade e não-eventualidade são termos que geraram debates no meio jurídico, onde não são vistos como sinônimos. Não-eventual é o trabalho que se realiza previsivelmente; com constância. Alguém que trabalhe todos os dias ou trabalhe nas segundas-feiras de todas as semanas, que trabalhe quinzenalmente ou que trabalhe em todas as primeiras segundas-feiras de cada mês; todos esses casos contam com a característica da não-eventualidade. O trabalho de diarista pode ter ou não essa característica. Tanto se pode contratar uma diarista uma vez por semana, sendo, assim, regular, não-eventual, quanto se pode contratá-la excepcionalmente, depois de uma festa ou para fazer uma faxina antes de uma mudança, por exemplo. A característica que essa modalidade de contratação de trabalho doméstico não tem, que a distingue da mensalista, é a continuidade (BERNARDINO-COSTA, 2007, p. 19, 177, 251; FRAGA, 2010, p. 28-32).

O trabalho contínuo, de acordo com o debate jurídico que se instaurou sobre a questão, motivado pela necessidade de definição legal de trabalhador doméstico, é aquele executado com frequência durante a semana. O trabalho contínuo sempre vai ser não-eventual,

\footnotetext{
${ }^{1}$ Fonte: PNAD 2014.

${ }^{2}$ No ano de 2013 esse percentual foi de $68,16 \%$, menor, portanto, que no ano seguinte. No entanto, não se tem quaisquer elementos que possam indicar se o aumento do percentual de trabalhadoras sem registro em 2014 é um fato pontual ou não.

${ }^{3}$ Fonte: PNAD 2014.

${ }^{4}$ Disponível em: http://www.planalto.gov.br/ccivil 03/leis/LCP/Lcp150.htm.
} 
mas nem sempre o trabalho não-eventual contará com a característica da continuidade. Apesar de ser o principal fator para se definir legalmente a mensalista, "continuidade" não tinha uma definição legal precisa, quanto ao número de dias, até a Lei Complementar 150, de 2015.

Antes da definição, porém, mas já entendida a continuidade como algo diferente da não-eventualidade - que a abrange -, esta era caracterizada por outros meios. Não havia dúvidas quanto ao fato de que quem trabalhasse cinco ou seis dias na semana fosse considerada mensalista, bem como não havia dúvida, diante daquele entendimento, de que quem trabalhasse um dia era diarista. Mas alguém que trabalhasse dois ou três dias pertencia a qual modalidade? Diante de tal quadro, entravam em cena questões como: "se o horário e os dias trabalhados eram fixos ou não, se o pagamento era mensal ou diário e se a trabalhadora prestava serviço em mais residências ou apenas em uma”, o que ajudava a fortalecer o convencimento jurídico sobre a autonomia da relação mantida (FRAGA, 2010, p. 34).

O quadro legal recentemente instituído aparentemente elimina problemas de entendimento e interpretações divergentes. Nesse contexto, a importância em trazer a indefinição que pairava sobre o tipo de relação entre empregadores e trabalhadoras domésticas está em esclarecer que essa questão se traduziu numa linguagem jurídica de forma a fazer que a realidade do trabalho doméstico escapasse por entre os dedos dos operadores do direito. Além disso, trazer pontos de vista discrepantes sobre o significado de "continuidade" que vigoravam no interior do pensamento jurídico, permite desnaturalizar a ideia de que as diferenças entre mensalistas e diaristas respalda direitos trabalhistas diferenciados.

Pautar a definição de trabalhadora doméstica preponderantemente pelo número de dias trabalhados deixa a descoberto um contingente crescente de trabalhadoras desse setor de serviços cuja proporção cresce cada vez mais, tendo passado de 19,61\%, em 2002, para 31,18\%, em 2014 (fonte: microdados PNAD 2002, 2014).45

\section{NOVOS CAMINHOS DO TRABALHO DOMÉSTICO}

Desde os anos 2000, houve sucessivos avanços do ponto de vista legal culminando com a promulgação da Emenda Constitucional 72, de 2013, que ampliou os direitos de trabalhadoras domésticas. Antes, havia na Consolidação das Leis do Trabalho e na Constituição dispositivos que distinguiam prestadoras dos serviços domésticos das demais ocupações, por isso eram assistidas por um número reduzido de direitos. A Emenda 72, no entanto, não põe 
fim à luta por reconhecimento. Essa conquista ainda deve superar dois problemas: aumentar a taxa de trabalhadoras registradas e reconhecer as diaristas como trabalhadoras domésticas.

Em 2015, diaristas passaram a poder se tornar seguradas do INSS como microempreendedoras individuais, pagando uma alíquota de 5\% de um salário mínimo. Desse modo têm direito apenas ao salário-maternidade, auxílio-doença, pensão por morte e aposentadoria por idade. Não tem qualquer direito a férias e a décimo-terceiro salário. Apesar da baixa alíquota, o percentual diaristas contribuintes ${ }^{5}$ é inferior ao percentual de contribuição de mensalistas. Enquanto o percentual de diaristas contribuintes (autônimas e com carteira assinada) era de $29,65 \%$ em 2014, o percentual de trabalhadoras mensalistas contribuintes era de $44,39 \%{ }^{6}$.

A diferenciação entre trabalhadoras diaristas e mensalistas foi reelaborada pelos avanços trazidos pela Emenda Constitucional 72. A carteira de trabalho abre espaço para uma outra qualidade de vida em função da segurança que ela proporciona.

Nesta dissertação, exceto em casos em que estejam explicitamente enunciados de que se tratam da definição jurídica, o termo "trabalhadoras domésticas" se refere ao conjunto formado por diaristas e mensalistas.

\section{JUSTIFICATIVA}

O trabalho doméstico até bem pouco tempo atrás constituía-se como ocupação com restrito amparo legal, quadro que mudou especialmente na última década. Paulatinamente, no entanto, os direitos foram conquistados ao longo de várias lutas políticas que já duram

\footnotetext{
5 "Contribuintes" abrangem contribuintes individuais e contribuintes com carteira assinada. Entre trabalhadoras que prestam serviço em mais de um domicílio (como se verá, a expressão é entendida como sinônimo de diarista), 70,35\% não são contribuintes, $12,37 \%$ têm carteira assinada e $17,28 \%$ são contribuintes individuais. Entre mensalistas esses percentuais são $55,61 \%, 38,35 \%$ e 6,04\%, respectivamente.

${ }^{6}$ É possível fazer esse cálculo com duas variáveis distintas da PNAD. Na variável utilizada, foi aferida a "contribuição para instituto de previdência em qualquer trabalho da semana de referência para pessoas de 10 anos ou mais de idade". Outra possibilidade seria através da variável que afere se a pessoa "era contribuinte para instituto de previdência no trabalho principal da semana de referência". Dado que a maior parte de trabalhadoras não só domésticas, mas também não-domésticas, adquirem sua remuneração num único trabalho, a diferença com base numa ou noutra variável fica restrita às casas decimais. Considerando o trabalho doméstico se o percentual total de não-contribuintes foi de $60,24 \%$, utilizando a outra variável seria de $60,39 \%$.
} 
mais de oitenta anos ${ }^{7}$. Embora o descumprimento da legislação trabalhista ainda seja grande, a prescrição legal tem se tornado cada vez mais efetiva.

Em 2013 foi aprovada a Emenda Constitucional que amplia direitos de trabalhadoras domésticas mensalistas, as "empregadas domésticas", equiparando-as às demais categorias profissionais do mercado de trabalho. A Emenda torna o Brasil um dos países com a legislação mais avançada no que diz respeito a esses direitos. De 117 países pesquisados pela Organização Internacional do Trabalho, 57,8\% são cobertos pelas mesmas leis trabalhistas que dizem respeito a outros trabalhadores ou são cobertos em parte pela regulação geral, em parte por regulações subordinadas ou leis específicas (como no caso do Brasil); 39,7\% têm limitações de horas normais de trabalho semanal igual ou inferior a de outras atividades; aproximadamente $49 \%$ dos países conferem aos trabalhadores domésticos o mesmo tempo de descanso semanal e de férias que trabalhadores de outras atividades; $51,3 \%$ estipulam o salário mínimo igual ou superior ao de outras ocupações; em $40,1 \%$ pode-se pagar a remuneração apenas em dinheiro; 63,3\% dos países apresentam licença-maternidade igual ou mais favorável que as outras ocupações e 58,3\% apresentam os mesmos direitos de recebimentos monetários durante a licença que as outras atividades do mercado de trabalho de seus países (OIT, 2013) $)^{8}$. Todas essas características são direitos de “empregadas domésticas” no Brasil hoje. Não bastasse o significado das mudanças legais, o Brasil é o maior empregador de trabalhadoras domésticas do mundo, o que torna a Emenda significativa não só no contexto nacional, mas também internacional.

A despeito disso, a mudança no quadro legal aconteceu no bojo de outras transformações: o aumento percentual de incorporação de mulheres ao mercado de trabalho na condição de diaristas, que conta com cobertura de direitos trabalhistas muito restrita, e a diminuição do peso do polo que se tornou plenamente reconhecido do ponto de vista legal no mercado de trabalho.

O recente quadro legal que amplia os direitos de trabalhadoras mensalistas não é suficiente para tornar efetivamente opostos, do ponto de vista da cobertura legal, o trabalho doméstico mensal e o da diarista. Isso significa que migração de mensalistas para o trabalho

\footnotetext{
${ }^{7}$ Laudelina de Campos Melo funda, em 1936, a Associação Profissional de Empregados Domésticos de Santos. Esse é um marco da luta pelo reconhecimento de trabalhadoras domésticas (BERNARDINO-COSTA 2007, p. 79).

${ }^{8}$ Disponível em: http://www.ilo.org/wcmsp5/groups/public/---dgreports/---dcomm/---publ/documents/publication/wcms 173363.pdf.
} 
de diarista não significa necessariamente perda de direitos por causa do percentual alto de mensalistas empregadas sem registro em carteira. Nesse sentido, há um longo caminho a ser percorrido rumo a adequação da realidade ao prescrito legalmente. Muitas vezes é pelo fato de patrões e patroas no trabalho mensal não cumprirem a legislação trabalhista que "empregadas" se tornam diaristas.

Noções de precarização têm sido utilizadas para tratar do serviço doméstico de contratação diária já que a transição de um trabalho regulamentado para um com parcos direitos (de empregada para diarista) se aproxima da imagem da perda de direitos e da flexibilização que diz respeito ao processo de precarização. Apesar disso, a possibilidade de rendimentos melhores e de fazer a contribuição previdenciária autonomamente, se não serviu para negar noções que atrelam essa forma de trabalho desregulamentado ao aumento da precarização, pelo menos tem sido usada para coloca-las em suspensão. No Brasil, de forma geral, o rendimento de trabalhadoras diaristas é maior que o de mensalistas, bem como o índice daquelas que pagam contribuição previdenciária, embora ainda seja menor, tem aumentado nos últimos anos a um ritmo mais intenso que o de mensalistas.

Posto isso, será possível ver que, a seu modo, ambas as razões presentes na teoria, o rendimento e a contribuição previdenciária, estão em diálogo, ainda que não de forma direta, com os relatos das trabalhadoras que colaboraram com esta pesquisa, embora aquelas razões não permitam ver a complexidade da situação que se impõe às trabalhadoras. As narrativas permitirão perceber porque o pressuposto sobre a possibilidade de rendimento maior não se confirma de forma satisfatória (ainda que de fato seja pouco maior) e quando se confirma de forma satisfatória, se dá sob condições que de modo algum podem ser suprimidas.

\section{ASPECTOS METODOLÓGICOS E CAPÍTULOS}

Esta pesquisa conta com dados quantitativos para dimensionar indicadores sobre mensalistas e diaristas extraídos da PNAD entre os anos 2002 e 2014, por meio do programa de análise de dados STATA. Esses dados, sugeridos pelas entrevistas feitas e pela bibliografia utilizada, referem-se, principalmente a rendimento, contribuição previdenciária, carteira de trabalho assinada, grau de instrução, escolaridade, características de migração, características raciais da população empregada, além de outros julgados necessários. 
A PNAD, principal instrumento usado para aferir dados estatísticos de trabalhadoras domésticas, não apresenta as categorias diarista e mensalista. A quantidade de mulheres ocupadas nelas é estimada a partir da quantidade de "trabalhadoras em mais de um domicílio" e "trabalhadora em um único domicílio", respectivamente. Se por um lado, existem mulheres que trabalham em mais de uma residência, mas que não são diaristas, são mensalistas que fazem "bicos" em outras casas; por outro lado, uma mensalista não tem muito tempo de sobra para fazer "bicos". Além disso, há que se considerar também que o número das que trabalham em uma residência dá conta com bastante precisão das trabalhadoras mensalistas. Essa estimativa é referendada amplamente por pesquisadores.

Paralelamente à coleta de dados quantitativos a partir de entrevistas semiestruturadas de oito trabalhadoras domésticas do Distrito Federal se trouxe narrativas sobre suas trajetórias de vida, experiências e perspectivas sobre e circunstâncias vivenciadas no trabalho doméstico. Estes relatos não se focavam apenas no presente, mas também em décadas atrás, quando se mudaram para a Capital Federal.

A análise dos dados é feita a partir de eixos temáticos sugeridos pelas entrevistas. Ela se baseia primeiramente em três elementos presentes nas narrativas: as representações (sobre o trabalho doméstico, sobre famílias empregadoras, sobre ser "fichada", etc.), as trajetórias (a migração, a transição do trabalho doméstico mensal para o de diarista, etc.) e a estrutura do trabalho doméstico (a especialização e as possibilidades abertas pelo que se entenderá por isso). A partir disso análise envolve o elemento quantitativo.

Essa dissertação divide-se em cinco partes, incluindo a introdução e a conclusão. $\mathrm{O}$ capítulo um se foca na articulação entre mulheres com experiência racializada de gênero e o lugar social subestimado no mercado de trabalho. Nesse contexto, serão também mostradas as mudanças legais ocorridas, ficando patente que o não reconhecimento de direitos de uma categoria de trabalhadores equivale a um mecanismo de produção de vulnerabilidade que é endereçado a uma população específica, as mulheres negras, que são as que executam essa atividade preferencialmente, sedimentando representações sobre o lugar social que incidem sobre elas.

No capítulo dois, as narrativas das entrevistadas são articuladas com a finalidade de contextualizar as falas e trazer com o máximo de densidade possível suas histórias dentro de um texto que possibilite a quem ler entrar numa relação empática com as interlocutoras desta 
pesquisa, possibilidade que fica mais distante quando se traz excertos de falas distribuídos entre temas e assuntos.

No terceiro capítulo, são enfocadas questões que levam ao esforço de identificação das trabalhadoras com o trabalho e os percalços que vivenciam em relação a ele. Dessa forma, será abordada a migração, seus significados, as consequências que ela traz para as experiências no trabalho doméstico e a importância do Distrito Federal nesse cenário de migração de trabalhadoras domésticas; o trabalho doméstico mensal e diário, questionando noções suscitadas atualmente, apontando para os problemas que a diarização traz para a vida de trabalhadoras. A partir dessa configuração serão discutidas noções difundidas como especialização e impessoalidade na diária, a possibilidade de ganhar mais e a busca por regularização no trabalho à luz daqueles critérios que emergiram da fala das entrevistadas. 


\section{TRABALHO DOMÉSTICO: RAÇA, GÊNERO E DIREITOS}

Esse capítulo é composto de duas partes. Na primeira, é enfocada a progressão do trabalho doméstico e dos seus direitos em dois momentos. Inicialmente, partir de um percurso histórico, é apontado como o trabalho doméstico ficou à margem dos nascentes direitos $\operatorname{trabalhistas}^{9}$ e sua associação com a desigualdade no mercado de trabalho. Posteriormente, tendo como pano de fundo um cenário em que prestadoras dos serviços domésticos se dedicam cada vez mais às diárias, aponto as leis promulgadas para o trabalho doméstico entre elas a Emenda Constitucional 72, de 2013 - EC 72 - que ampliou os direitos de trabalhadoras domésticas no país. Na segunda parte, é retratado o quadro de genderização e racialização que alimenta o trabalho doméstico. O objetivo do capítulo é mostrar o potencial da legislação em atualizar a articulação entre um lugar social com poucos direitos e a experiência racializada de gênero.

\subsection{DiREITOS DE TRABALHADORAS DOMÉSTICAS ONTEM E HOJE}

Existem tendências opostas de crescimento dos serviços domésticos remunerados, de um lado, e a ampliação de vagas de trabalho não-doméstico, como o fabril e demais atividades com carteira assinada e direitos e salários garantidos, de outro. Fazendo uma descrição breve dessa evolução antagônica, entre 1930 e 1980, com a estruturação do mercado de trabalho no Brasil, houve uma queda do peso do trabalho doméstico para a população feminina empregada. A partir de 1980 até os anos 2000, o movimento no mercado de trabalho se inverte. Aquele tipo de trabalho que incorporava a população economicamente ativa ao assalariamento e ao trabalho regulado por convenções trabalhistas passa a demitir e a ser substituído por trabalhos desregulamentados. Nesse momento, após 1980 até os anos 2000, aumenta o peso do trabalho doméstico para a população feminina empregada. (POCHMANN, 2006).

Essa tendência oposta se baseia no fato de que a difusão do trabalho regularizado com carteira assinada e direitos garantidos leva à diminuição da desigualdade social, que é a situação inversa da que leva ao aumento do trabalho doméstico. O trabalho doméstico é tanto mais comum quanto maior a concentração de renda, já que, em princípio, se baseia na

\footnotetext{
${ }^{9} \mathrm{O}$ mesmo acontecendo com o trabalho rural. Não será explorado aqui as consequências disso, mas chama atenção que em vários momentos ao longo deste trabalho se verá o trabalho agrícola próximo ao trabalho doméstico em várias questões enfocadas.
} 
diferença de poder aquisitivo entre empregadora e trabalhadora. Apenas para citar uma evidência disso, de acordo com dados de 2008-2009, 58\% das trabalhadoras domésticas são empregadas por $10 \%$ das famílias mais ricas da população. Do total de famílias nesse grupo de poder aquisitivo, 70\% empregam trabalhadoras domésticas (BERNARDINO-COSTA, 2015, p. 148). Esse cenário de desigualdade se deve, em parte à estruturação do mercado de trabalho.

Não é ocasional que 1930, marco da industrialização no país, se configure como marco da estruturação do mercado de trabalho. Em 1929, devido à queda da bolsa de Nova York e nas exportações de café, Getúlio Vargas se volta para o mercado interno nacional, adotando uma política de fechamento da economia. O cenário econômico brasileiro era dominado pelo déficit. O café, na condição de principal produto de exportação, aliviava a balança comercial brasileira impedindo que o déficit fosse maior. A exportação desse produto correspondia a $60 \%$ das importações de produtos industrializados e bens de consumo feitas pelo Brasil. Com a queda da bolsa de Nova York as exportações se retraem e levam Getúlio Vargas a se voltar para o mercado interno adotando uma política de fechamento da economia do país e de desenvolvimento da indústria (SILVA, 2015, p. 27).

Nesse cenário são gestadas as leis trabalhistas que começaram a ser promulgadas a partir de 1931 e vão se sedimentar na Consolidação das Leis Trabalhistas - a CLT -, em 1943. A produção era o eixo que garantia direitos e o trabalho doméstico estava excluído dele. Aliás, o nome do Ministério do Trabalho, desde a sua criação no final de 1930 até 1960 era Ministério do Trabalho, Indústria e Comércio ${ }^{10}$; um alinhamento significativo do que é marginalizado nesse cenário. Assim, com a promulgação da CLT houve a exclusão expressa não apenas de trabalhadores e trabalhadoras domésticas através do seu artigo $7^{011}$, como também, neste mesmo artigo, dos trabalhadores e das trabalhadoras rurais. Apesar de várias leis esparsas para o trabalhador rural, a equiparação entre estes e os urbanos foi conseguida com a Constituição de 1988 (SILVA, 2015, p. 33); quanto ao trabalho doméstico, só o foi conseguida em 2015. Convém notar que a situação de desigualdade impressa nesse momento da institucionalização da CLT repercute até a atualidade. Ambos têm os maiores índices de

\footnotetext{
10 Disponível em: http://www.biblioteca.presidencia.gov.br/base-legal-de-governo/orgaos-extintos/copy17_of_ciencia-e-tecnologia.

11 Disponível em http://www2.camara.leg.br/legin/fed/declei/1940-1949/decreto-lei-5452-1-maio-1943415500-publicacaooriginal-1-pe.html.
} 
informalidade no mercado de trabalho, ambos têm os menores rendimentos, ambos são marcados pela baixa escolaridade e ambas são racializadas.

Assim, a promulgação do decreto-lei 5.452, de maio de 1943 - a CLT - pode ser lida não simplesmente como um instrumento que atribui direitos, mas também como um dispositivo que visava, a partir do momento histórico de então, favorecer a industrialização, mas criou, concomitantemente, grupos excluídos. Esse se constitui um processo de outrificação semelhante àquele por que passou a população negra após a abolição, quando, com a imigração europeia e o fim da escravidão, os negros foram expulsos das áreas de maior desenvolvimento econômico, especialmente do Sudeste para ocupações periféricas da economia capitalista em expansão e para áreas rurais depauperadas (HASENBALG, 1979, p. 151-160; FERNANDES, 1965). Sabidamente, no entanto, esses dois processos se aplicam diferencialmente à população masculina e feminina, haja vista que "o estrato feminino da população negra teve, em bloco, condições favoráveis de transição mais ou menos estável para o novo estilo de vida" (FERNANDES, 1965, p. 82) porque "várias condições favoreciam a estabilidade da mulher negra como e enquanto serviçal doméstica ${ }^{12 "}$ (p.81). Existem alguns problemas na constatação do autor na medida em que não revela o custo dessa transição mais “favorável” à mulher negra; não revela se isso significou ter de se separar do seu grupo ou família nem revela as condições em que permaneciam nos serviços domésticos. Mas ambos os processos trazem consigo a marginalização ocupacional dos não brancos, de forma intencional, no caso do processo de substituição da mão-de-obra negra pela imigrante entre 1888 e 1930, e como efeito colateral ao alijar o trabalho doméstico de direitos. "Efeito colateral"13

\footnotetext{
${ }^{12}$ Com grifos no original.

${ }^{13}$ O termo "colateral" é problemático, mas se refere ao fato de o alijamento de direito ser voltado ao trabalho doméstico, não à população negra. Não se pode obliterar, no entanto, que a colateralidade pode ser efeito justamente do desinteresse que determinadas ações ou faltas de ação têm sobre determinados grupos. Nunes (1993), na sua tese de doutorado, lança uma indagação retórica em que insinua que se o trabalho doméstico fosse executado por homens possivelmente teria reconhecimento legal. Também Bandeira e Almeida (2011, p.7) argumentam que "Há décadas, Ortner e Whitehead (1981) mostraram que a equivalência entre a masculinidade (e suas atividades correlatas) e o lócus de prestígio social é capaz de contaminar com seu status superior as ações e os campos de atuação que se encontram a cargo dos homens - apesar do caráter não fixo das tarefas ao longo do tempo e através das sociedades. Assim, não são os trabalhos sob a responsabilidade dos homens o que lhes confere sua importância. Os ofícios ganham distinções dentro da lógica relacional hierárquica, estabelecida pelo predomínio do pensamento binário que polariza o masculino e o feminino, o público e o privado, a cultura e a natureza, trazendo o primeiro termo em posição de destaque e o segundo subordinado a ele. Em suma, os homens é que dotariam de prestígio as tarefas que realizam, fazendo de masculinidade e status qualidades intercambiáveis, bem como reforçariam seu prestígio ao desempenharem exatamente tais atividades já valorizadas no imaginário social, uma vez que as qualidades masculinas são consideradas positivas". Embora as três autoras tenham como foco a perspectiva de gênero, é possível relacionar esse mesmo modus operandi à perspectiva racial, lançando uma camada interpretativa sobre processos que,
} 
(haja vista que não direcionado especificamente para a população não branca) por esse seguimento ocupacional contar com maior parte da mão-de-obra de mulheres pretas e pardas e, principalmente, pela importância que essa ocupação tem na integração dessas mulheres ao mercado de trabalho.

Hasenbalg (1979) demonstra que negros e brancos colocados em uma mesma condição inicial de igualdade com o tempo se tornam desiguais. Demonstra isso através da constatação de que o imigrante estrangeiro que chegava ao país em condição não muito distinta de negros livres conseguiam uma realização de status superior à alcançada pela população negra. Com isso ele aponta que a escravidão não é a única responsável pela desigualdade de status e pelas condições da população negra frente à branca. Tal situação se mantém por mecanismos que a atualizam. Nessa medida, a desigualdade conferida pela Consolidação das leis trabalhistas atua como mecanismo que atualiza a desigualdade tanto do ponto de vista racial, quanto do ponto de vista do gênero.

No contexto de estruturação do mercado de trabalho no Brasil, a partir de 1930, os direitos trabalhistas orbitavam o setor industrial que despontava no país. Este cenário, ao pautar a institucionalização nascente do próprio Ministério do Trabalho e as leis por ele promulgadas, que mais tarde foram reunidas na Consolidação das Leis Trabalhistas, colocou à sombra não só trabalhadores e trabalhadoras domésticas como também rurais. Assim, utilizando os termos originais da CLT, de 1943, embora a Consolidação estabeleça "as normas que regulam as relações individuais e coletivas de trabalho, nela previstas"; considere "empregado toda pessoa física que prestar serviços de natureza não eventual a empregador, sob a dependência deste e mediante salário"; e determine expressamente que "não haverá distinções relativas à espécie de emprego e à condição de trabalhador, nem entre o trabalho intelectual, técnico e manual”, ainda assim, o trabalho doméstico e rural foram colocados à parte (BRASIL, 1943) $)^{14}$.

Entre 1970 e 1980, houve uma grande queda do percentual da população feminina economicamente ativa incorporada ao mercado de trabalho pelos serviços domésticos remunerados, passando de $27 \%$ para $19,9 \%$. Nesse mesmo período o emprego feminino cresceu 92\% (MOTTA, 1992, p. 6). A expectativa tida antes da década de 1970 era de que o trabalho

embora não tenham como foco explícito pessoas negras, as convertem no principal sujeito paciente. Assim, a colateralidade adquire contornos de uma efetiva política de exclusão.

${ }^{14}$ Disponível em http://www.planalto.gov.br/ccivil 03/decreto-lei/Del5452.htm. 
doméstico desapareceria, segundo previa teóricos como Lewis Coser (1973). Harris argumenta que o erro da predição de Coser não estava na avaliação do contexto, mas, sim, na mudança de curso promovida pelo novo cenário do mundo do trabalho que aumentou a desigualdade nesses países (HARRIS, 2007, p. 40). Por outro lado Hondagneu-Sotelo (2001) aponta que não houve uma mudança no curso da história que levou a um inesperado aumento do peso do trabalho doméstico para a população feminina. Esse aumento já era esperado pelo próprio processo de modernização ${ }^{15}$ :

Não é à toa que essas previsões dos anos 1970 foram feitas por homens. Esses acadêmicos [Coser (1973) e Chaplin (1978)] subestimavam não só a compatibilidade entre modernização e desigualdade socioeconômica, mas também as aparentemente intermináveis atividades requisitadas para a manutenção das casas e o cuidado com as crianças. Eles também falharam em reconhecer que tecnologias que auxiliam no cuidado doméstico, junto à elevação nos padrões de higiene e de criação de crianças da classe média no século $\mathrm{XX}$, tem frequentemente aumentado, em vez de diminuir, número de horas de trabalho doméstico (HONDAGNEU-SOTELO, 2001, apud HARRIS, 2007, p. 40).

O fim da era nacional-desenvolvimentista, na década de 1980, afeta a economia e a oferta de empregos, atingindo de forma diferente homens e mulheres. Desde 1970, o crescimento da taxa de atividade feminina permaneceu expressivo, persistindo até por volta de 2008, ao passo que a taxa de ocupação masculina diminuiu, em especial entre as décadas de 1980 e 1990 (BRUSCHINI, 2007; DUTRA; MORI, 2008; HOFFMAN; LEONE, 2004; SALAS; LEITE, 2008). Assim, tem-se o aumento da importância da renda feminina na manutenção da família e o aumento da desigualdade. Se, por um lado, esse cenário favoreceu a contratação de trabalhadoras domésticas por mulheres que adentravam no mercado de trabalho não-doméstico, por outro, o cenário de recessão, desemprego e baixo conhecimento das leis não favorecia o cumprimento da legislação recente que obrigava a assinatura da carteira de trabalhadoras domésticas, de modo que o trabalho doméstico voltava a florescer em meio à precarização do mercado de trabalho e ao aumento da desigualdade.

Em todo esse período, até a Constituição de 1988, apenas duas leis foram promulgadas em favor de trabalhadores e trabalhadoras domésticas. A primeira é a Lei $n^{\circ} .5 .859$ de 1972 (PINHEIRO; FONTOURA; PEDROSA, 2012 p. 95), regulamentada pelo Decreto

\footnotetext{
${ }^{15}$ Brites (2004, p. 3-4), aponta que, no Brasil, a afirmação da incongruência entre desigualdade e modernidade aparecem pelos estudos de: Saffioti (1978), Motta (1977), Oliveira, (1981), Farias, (1983), Chaney; Garcia Castro, (1993).
} 
71.885 de 1973, foi a que regulamentou o trabalho doméstico. Ela obrigava a assinatura da Carteira de Trabalho, dando, consequentemente, direito à Previdência social e ao gozo de férias, inicialmente de vinte dias. A segunda é a Lei no . 7.619, de 1987 (regulamentada pelo Decreto $n^{\circ} .95 .247$, também de 1987), que obrigava o empregador a pagar o vale-transporte ao trabalhador e a trabalhadora doméstica (CFEMEA, 2007, p. 7-10; FRAGA, 2010, p. 2126; MORI et al, 2011, p. 20-25) ${ }^{16}$.

A conquista do reconhecimento do trabalho doméstico, em 1972, se deu dentro de uma discussão que tinha como pivô a noção de classe trabalhadora, ainda que perspectivas pautadas na raça e no gênero não estivessem de todo ausentes (BERNARDINO-COSTA, 2007 , p. 85,$88 ; 2015$, p.156). Em tal cenário, tendo como eixo a produção, o reconhecimento acabou por definir a especificidade do trabalho doméstico como não gerador de lucro, alicerçando o argumento de que este deveria ter direitos distintos (BRITES, 2014, p. 131). Definido pela falta e não pelo que tem de essencial - ser trabalho de reprodução da vida e dos cuidados necessários a ela (GUTIÉRREZ-RODRÍGUEZ, 2013: 125; COLEN, 1995) alguns direitos foram conquistados, mas de forma a apontar sua unicidade frente à outras categorias.

A Constituição de 1988 trouxe um realinhamento na organização de trabalhadoras domésticas que se tornou crucial para conquistas futuras. Depois do V Congresso das Trabalhadoras Domésticas, acontecido na cidade de Olinda, em 1985, aumentou a mobilização da categoria como um todo para conseguir a extensão dos seus direitos na nova Constituição. Embora, na Constituinte, a categoria não tenha sido contemplada por propostas encampadas pela Central Única dos Trabalhadores, entidade sindical que representava os trabalhadores e trabalhadoras, houve uma aproximação entre movimentos feministas e trabalhadoras domésticas (BERNARDINO-COSTA, 2007, p.100). A ONG SOS Corpo - Instituto Feminista para a Democracia financiou duas assessoras para o Sindicato de Trabalhadoras Domésticas do Recife para fortalecer as articulações para a Constituinte (p. 155). O Conselho Nacional dos Direitos da Mulher, no âmbito da campanha "Mulher e Constituinte", de 1985, lançou a “Carta das Mulheres aos Constituintes de 1987”. Nela havia princípios gerais e específicos

\footnotetext{
${ }^{16}$ O Decreto-Lei 3.078, de 1941, que tornaria obrigatória a carteira profissional, dentre outros direitos não foi regulamentado. A Lei 2.757, de 1956, tratava de diferenciar trabalhadores domésticos de trabalhadores de prédios residenciais a serviço da administração do edifício para incorporar esses últimos a Consolidação das Leis Trabalhistas. A Lei 3.807, de 1960, permitia o empregado doméstico filiar-se à Previdência Social. Sendo facultativa essa lei não causou nenhum impacto. A Lei $\mathrm{n}^{\circ}$. 7.418, de 1985 instituía o vale-transporte, também facultativo (FRAGA, 2010: 21-24).
} 
que reivindicavam soluções para dificuldades enfrentadas por trabalhadoras domésticas. Em menção direta a categoria, reivindicava, num de seus pontos, a "extensão dos direitos trabalhistas e previdenciários de forma plena às empregadas domésticas e às trabalhadoras rurais" (DUTRA; MORI, 2008, anexo 2). Mais tarde, por volta da década de 1990 aumenta a interação do movimento de trabalhadoras domésticas com o movimento negro. A partir do VI Congresso Nacional de Trabalhadoras Domésticas, ocorrido em Campinas em 1989, embora não seja abandonada a referência à classe operária, passa-se a debater a discriminação racial no trabalho doméstico e cada vez mais os dois campos passam a se interseccionar (BERNARDINO-COSTA, 2007, p. 210, 211, 2017, 222, 228).

Antes da Constituição, trabalhadoras domésticas tinham direito à carteira assinada, férias de vinte dias, aposentadoria. Com a Constituição, embora não tenham conseguido a equidade de direitos em relação aos demais trabalhadores conseguiram:

Quadro 1: DIREITOS ASSEGURADOS PELA CONSTITUIÇÃO DE 1988 PARA O TRABALHO DOMÉSTICO - BRASIL

\section{Direitos Constitucionais assegurados antes da EC 72/2013}

Garantia de salário, nunca inferior ao mínimo

Irredutibilidade do salário, salvo o disposto em convenção ou acordo coletivo

Décimo terceiro salário com base na remuneração integral ou no valor da aposentadoria

Repouso semanal remunerado, preferencialmente aos domingos

Férias anuais remuneradas com, pelo menos $1 / 3$ a mais do que o salário normal

Licença à gestante, sem prejuízo do emprego e do salário, com duração de 120 dias

Licença-paternidade nos termos fixados em lei

Aviso prévio proporcional ao tempo de serviço, sendo no mínimo de trinta dias Aposentadoria

Outra possibilidade trazida com a Constituição foi a de trabalhadoras poderem se organizar em sindicatos. Como efeito disso, associações que já existiam se converteram em Sindicatos de trabalhadoras, fornecendo um referencial para a luta de trabalhadoras domésticas.

É importante trazer à tona a influência dos alinhamentos (com a classe trabalhadora ou com grupos feministas ou movimento negro) nos termos que orbitaram a gramática da busca por direitos. Embora sob a égide do primeiro alinhamento se obteve o reconhecimento da ocupação em 1972, paralelamente é ressaltada a diferença entre trabalhadoras domésticas e outras categorias presentes no mercado de trabalho. Nessa medida, a fuga dessa gramática pré-determinada é prenhe de significado. A partir da década de 1980, existe uma aproxima- 
ção maior de associações de trabalhadoras domésticas (o direito a se constituírem em sindicatos só virá mais tarde) e movimentos negros e feministas que trazem outro referencial para se pleitear a busca por equidade legal. Então, se obtém novas conquistas com a Constituição de 88. Embora não exatamente nesses termos (em especial por diferenças na concepção do primeiro alinhamento), a ação eficaz que esse realinhamento promove dialoga com o que Bernardino-Costa (2015) chama de interseccionalidade emancipadora.

A virada do século trouxe um período de mudanças. O peso do trabalho doméstico que respondia por $17,41 \%$ do emprego feminino em 2002 cai para $13,95 \%$ em $2014^{17}$. Além disso, houve mudanças mais significativas no quadro legal pertinente às trabalhadoras domésticas. A Lei 10.208, de 2001 facultou a inclusão da trabalhadora doméstica no o Fundo de Garantia por Tempo de Serviço e ao seguro-desemprego. A Lei 11.324, de 2006: 1) vedou descontos referentes à vestuário, alimentação, higiene e moradia; 2) aumentou o período de férias de vinte para trinta dias, assegurando a sua remuneração e o acréscimo de 1/3 do salário a mais que os recebimentos regulares a cada doze meses trabalhados; 3) assegurou a estabilidade a gestante por até cinco meses depois do parto; permitiu deduzir a contribuição patronal do INSS do imposto de renda (se for referente ao rendimento de uma (01) trabalhadora que receba até um salário mínimo) e, por fim, 4) passou a garantir descanso semanal remunerado, revogando disposições em contrário de leis anteriores que se aplicavam exclusivamente a prestadoras de serviços domésticos. O Decreto $n^{\circ}$. 6.481, de 2008 proibiu o trabalho de menores de dezoito anos nas atividades presentes na Lista das Piores Formas de Trabalho Infantil (cuja indicação é feita na Convenção 182, de 1999, da OIT), dentre as quais está o trabalho doméstico. A aquisição de maior impacto para trabalhadoras domésticas foi a Emenda Constitucional 72, de 2013 (CFEMEA, 2007, p. 7-10; FRAGA, 2010, p. 21-26; MORI et al, 2011, p. 20-25). No âmbito internacional a Convenção 189 da Organização Internacional do Trabalho - OIT - que obrigava os países membros a erradicarem a discriminação de trabalhadoras domésticas frente a outras categorias de trabalhadores no âmbito legal, embora não tenha sido ratificada pelo país, exerceu forte pressão para a aprovação da PEC.

\footnotetext{
${ }^{17}$ Não se pode perder de vista que números e percentuais estão sujeitos a variações de leitura de acordo com os enquadramentos feitos. No trabalho doméstico, os enquadramentos que mudam o "valor" e a significação de determinados índices podem se referir ao total de mulheres, ao total de mulheres empregadas no mercado de trabalho, ou ao total de trabalhadoras domésticas, cada enquadramento traz consequências, omitindo algumas coisas e revelando outras (ver anexo $\mathrm{C}$ ).
} 
Como se percebe, a definição de trabalhador doméstico adotada pela Convenção 189 é bem mais ampla, aproximando-se do contido no artigo $3^{\circ}$ da CLT, enquanto a definição adotada pela lei brasileira, que disciplina o trabalhador doméstico como aquele que presta serviços para o mesmo empregador por mais de duas vezes por semana, alija da proteção legal a chamada "diarista" doméstica, em hermenêutica claramente excludente. A Convenção 189 exclui do conceito de trabalhador doméstico apenas aquele que não faça desse trabalho sua ocupação profissional habitual; o legislador brasileiro, de forma ampliativa e, desse modo, reducionista de direitos, privou da proteção legal aqueles que fazem do trabalho doméstico sua ocupação habitual, prestando serviços para vários empregadores em uma mesma semana, por meio de relações de trabalho que podem perdurar por anos (OLIVEIRA, 2016, p. 28)

A Convenção 189 da OIT, de 2011, que entrou em vigor em 2013, não foi ratificada pelo Brasil. Apesar disso, "trouxe profundas transformações nas relações de trabalho doméstico no Brasil”, uma vez que "impulsionou a aprovação da Emenda Constitucional 72/2013" (OLIVEIRA, 2016, p. 26). Essa convenção se trata da primeira norma internacional, produzida num esforço conjunto de vários setores organizados de vários países para tentar assegurar condições de trabalho decentes e direitos para trabalhadoras domésticas.

A partir dessas discussões, no Brasil, foi aprovada, em 2013, a Emenda Constitucional 72, contando também com a ampla participação de setores com interesses conexos, dentre os quais, setores envolvidos com questões raciais, de gênero e relativos ao trabalho doméstico propriamente. Só em abril de 2013, 70 anos depois da promulgação da carta que reconhecia os direitos trabalhistas no Brasil, foi promulgada a Emenda Constitucional 72, que ampliou os direitos das trabalhadoras domésticas equiparando-as aos demais trabalhadores. A regulamentação da emenda durou até 2015.

A Emenda Constitucional em questão comportava direitos de eficácia plena e direitos de eficácia contida. Direitos de eficácia plena são aqueles para os quais bastam a promulgação para começarem a valer imediatamente. Direitos de eficácia contida são aqueles para os quais é imprescindível o estabelecimento de regras para que viabilizem seu cumprimento. O estabelecimento dessas regras é chamado de regulamentação. Enquanto os primeiros começaram a valer em 2013, os últimos só tiveram o processo de regularização concluído 2 anos depois (ver quadro 2). 


\section{DIREITOS ASSEGURADOS COM A EC 72/2013 LEIS DE EFICÁCIA PLENA LEIS DE EFICÁCIA CONTIDA}

Garantia de salário, nunca inferior ao mínimo, para os que percebem remuneração variável;

Fundo de Garantia do Tempo de Serviço (FGTS);

Relação de emprego protegida contra despedida arbi-

Proteção do salário na forma da lei, constituindo crime sua retenção;

Remuneração do serviço extraordinário superior, no mínimo, em 50\% à do normal;

Redução dos riscos inerentes ao trabalho, por meio de normas de saúde, higiene e segurança;

Reconhecimento das convenções e acordos coletivos de trabalho;

Proibição de diferença de salários, de exercício de funções e de critério de admissão por motivo de sexo, idade, cor ou estado civil;

Proibição de qualquer discriminação no tocante a salário e critérios de admissão do trabalhador portador de deficiência;

Duração do trabalho normal de até 8 horas diárias e 44 semanais, facultada a compensação de horários e a redução da jornada por acordo ou convenção coletiva. $\mathrm{O}$ que exceder as 44 horas semanais pode ser paga como hora extra desde que não se exceda 10 horas de trabalho diárias.

Discussões em torno da Emenda, ocorridas na época em que esta era apenas uma Proposta (a chamada PEC 66 - Proposta de Emenda Constitucional 66), tiveram o efeito de dar visibilidade às injustiças sofridas por trabalhadoras domésticas e ajudar a aumentar, ainda que timidamente, o percentual de mensalistas registradas. $\mathrm{O}$ aumento de percentual se deve também ao fato de que, embora existam poucos mecanismos para garantir a legalidade no interior do ambiente doméstico, é fato que trabalhadoras têm cada vez mais procurado seus direitos e paulatinamente aumenta sua confiança em recorrer à justiça. Sem dúvida a adesão sindical, que no Brasil ainda é muito baixa, auxilia nesse processo. No bojo desse momento que parece criar as condições para uma nova consciência ${ }^{18}$ em relação ao trabalho doméstico, para estimular a formalização das trabalhadoras, o governo federal criou o pro-

\footnotetext{
${ }^{18}$ Como afirma Brites (2000), "as perspectivas "modernas" de participação política repercutem nas relações de trabalho entre patrões e empregados, na atitude, cada vez mais difundida entre os patrões, de que um compromisso contratual, respeitando os princípios legais, define relações mais justas".
} 
grama "eSocial" para dar suporte operacional à recente legislação regulamentada, permitindo ao empregador enviar informações de seus trabalhadores domésticos remunerados de forma mais simples. O eSocial é responsável pelo "Simples Doméstico": uma guia única contendo as contribuições fiscais, trabalhistas e previdenciárias ${ }^{19}$, substituindo, assim, várias guias que eram usadas até então, como as guias de FGTS, de INSS (ver vocabulário no anexo I) e a de Imposto de Renda Retido na fonte para as trabalhadoras que ganham mais de $\mathrm{R} \$$ 1.903,98 (de acordo com tabela reajustada pelo governo).

Hoje, no Brasil, o imposto recolhido para regularização de trabalhadoras domésticas equivale a $28 \%$ do salário delas. Desses, $20 \%$ são pagos pelos empregadores e $8 \%$ é descontado do rendimento da trabalhadora. Os empregadores e empregadoras podem descontar a sua parte do encargo do INSS (8\%) do Imposto de Renda, desde que esse encargo incida sobre um salário e para uma única trabalhadora (um único trabalhador). Além desses encargos, quem emprega também deve pagar o vale transporte, podendo descontar no salário da trabalhadora no máximo $6 \%$ do valor do seu rendimento.

Quadro 3: ENCARGOS PATRONAIS E EMPREGATÍCIOS A SEREM PAGOS POR EMPREGADORES DE TRABALHADORAS DOMÉSTICAS

\begin{tabular}{|c|c|}
\hline $\begin{array}{l}\text { ENCARGOS PATRONAIS: } 20 \% \text { (vinculado } \\
\text { ao simples doméstico) }\end{array}$ & $\begin{array}{l}\text { DESCONTO NO SALÁRIO DO EMPRE- } \\
\text { GADO }\end{array}$ \\
\hline $8 \%$ de INSS & \multirow{3}{*}{$8 \%$ a $11 \%$ para INSS ${ }^{20}$} \\
\hline $\begin{array}{l}8 \% \text { para o FGTS (dedutível do imposto de renda } \\
\text { se for 1) de uma única trabalhadora, 2) sobre um } \\
\text { salário mínimo. }\end{array}$ & \\
\hline $\begin{array}{l}3,2 \% \text { de fundo para demissão sem justa causa; } \\
0,8 \% \text { de seguro acidente. }\end{array}$ & \\
\hline ENCARGO CONTINGENE PATRONAL & DESCONTO DO EMPREGADO \\
\hline Vale transporte & $\begin{array}{l}\text { Possibilidade de descontar até } 6 \% \text { do valor do } \\
\text { salário pago. }\end{array}$ \\
\hline
\end{tabular}

Apesar da multa de no mínimo R \$ 805,00 para o empregador que não assinar a carteira de trabalho, o percentual de trabalhadoras domésticas registradas é de 30,25\%. Desses, 26,4\% são mensalistas e 3,86\% diaristas (microdados PNAD 2014, extração própria).

19 Disponível em: http://www.previdencia.gov.br/2015/09/esocial-cadastro-do-empregado-domestico-comeca-em-1o-de-outubro/.

${ }^{20}$ A alíquota depende do rendimento do trabalhador/trabalhadora (não é específica para o trabalho doméstico), sendo de $8 \%$ para quem ganha até $\mathrm{R} \$ 1.556,94$; de $9 \%$ para quem ganha de $\mathrm{R} \$ 1.556,95$ até $\mathrm{R} \$ 2.594,92$; de $11 \%$ para quem ganha de $\mathrm{R} \$ 2.594,93$ até $\mathrm{R} \$ 5.189,82$, que é o teto do salário-de-benefício e do salário-decontribuição. A previdência social divulga anualmente a tabela atualizada com os percentuais das alíquotas a serem cobradas. Salário mínimo atual é de R \$ 880,00. Dados referentes ao ano de 2016. Disponível em: http://www.previdencia.gov.br/servicos-ao-cidadao/todos-os-servicos/gps/tabela-contribuicao-mensal/. 
É recorrente a alegação de que a Emenda tem levado empregadores e empregadoras a substituírem trabalhadoras mensalistas por diaristas para fugir dos encargos. De fato, a tabela abaixo mostra uma tendência de aumento do percentual de trabalhadoras diaristas que vinha ocorrendo desde 2002. Entre 1995 e $2002^{21}$ houve um aumento de pouco mais de $1 \%$ de participação de diaristas no trabalho doméstico, passando a sua participação total de 18,3 para $19,6 \%$ (IPEA, 2012, p. 10) $)^{22}$.

Tabela 1: VARIAÇÃO DO PERCENTUAL DE TRABALHADORAS DOMÉSTICAS DIARISTAS ENTRE 2002-2014 (EM \%) - BRASIL

\begin{tabular}{|l|c|c|c|c|c|c|c|c|c|c|c|c|}
\hline $\begin{array}{l}\text { Ano } \\
\text { diaristas }\end{array}$ & $\mathbf{2 0 0 2}$ & $\mathbf{2 0 0 3}$ & $\mathbf{2 0 0 4}$ & $\mathbf{2 0 0 5}$ & $\mathbf{2 0 0 6}$ & $\mathbf{2 0 0 7}$ & $\mathbf{2 0 0 8}$ & $\mathbf{2 0 0 9}$ & $\mathbf{2 0 1 1}$ & $\mathbf{2 0 1 2}$ & $\mathbf{2 0 1 3}$ & $\mathbf{2 0 1 4}$ \\
\hline Fonte: & 21,41 & 22,07 & 24,26 & 25,49 & 26,55 & 29,33 & 30,58 & 29,31 & 30,76 & 31,18 \\
\hline
\end{tabular}

Ainda que o aumento percentual de diaristas não exclua a possibilidade de fuga das obrigações trabalhistas, este tem mostrado tendências perenes de crescimento desde 2002, ao passo que, depois da Constituição de 1988, novas mudanças robustas no quadro legal que assiste mensalistas só foram acontecer depois de 2006, assinalando que outras mudanças comportamentais e ambientais (como as da arquitetura, por exemplo) tiveram influência no aumento de diaristas.

Nunes e Silva (2013) argumentam que "o aumento do número de diaristas não implica, necessariamente, em aumento da precariedade do trabalho" (2013, p. 595). Os autores amparam seus argumentos no valor da hora de trabalho superior da diarista e do consistente aumento da proporção de contribuintes para a previdência social tanto por parte de diaristas quanto de mensalistas. Esse aumento apresentou taxas de crescimento semelhantes para as duas modalidades contratadas entre 2004 a 2011, embora a porcentagem de contribuintes em

\footnotetext{
${ }^{21}$ Motta (1992) traz algumas informações que permitem fazer deduções sobre a progressão do trabalho doméstico na modalidade prestada pela diarista. A autora aponta que entre 1970 e 1980 a contribuição do serviço doméstico para a População Economicamente Ativa passou de 27\% para 19,9\%. Nesse mesmo período, conta a autora, o emprego feminino cresceu 92\%. É quase impossível que esse cenário de queda da taxa de incorporação de mulheres ao trabalho doméstico, dada a sua intensidade, afetasse apenas o trabalho da mensalista. Provavelmente, portanto, por um lado, a diminuição do trabalho doméstico se distribuía pelos dois seguimentos do trabalho doméstico. Por outro lado, a autora relata no período atual ao que escreve "o aumento significativo do número de diaristas disponíveis, assim como de famílias empregadoras que preferem recorrer aos serviços destas, seja para complementar o trabalho de mensalistas, como faxineiras ou lavadeiras, seja como empregadas únicas - não raro requisitadas até por dois ou três dias por semana - já aí em uma gama de serviços que inclui, também, a cozinha, principalmente para o congelamento de alimentos" (1992, p. 6). Dado que entre 1995 e 2002 o trabalho da diarista apresentou crescimento quase nulo e provavelmente apresentou queda ente 1970 e 1980, o período de crescimento substantivo do trabalho de diarista que o fez se aproximar dos níveis que apresentava em 2002 ocorreu entre os anos de 1980 e 1995, aproximadamente.
}

22 Disponível em: http://www.ipea.gov.br/agencia/images/stories/PDFs/nota tecnica/120830 notatecnicadisoc010.pdf. 
cada um desses dois grupos seja diferente, atingindo $39 \%$ das mensalistas e $25,7 \%$ das diaristas.

Fraga (2010) analisa os processos de mudança do emprego doméstico, dando especial atenção para o aumento da formalização de mensalistas e ampliação do percentual de diaristas - a diarização. Embora concorde que a diarista assuma riscos por não contar com a proteção legal, o autor argumenta que isso não significa precarização, frisando a possibilidade de a diarista obter rendimentos maiores e de poder contribuir autonomamente para o INSS.

Apesar de não mencionar o termo precarização, Silveira e Libardoni (2014) argumentam que o processo de diarização consiste em retrocesso para as relações de emprego doméstico. Para eles, com o êxito da Emenda Constitucional 72/2013, o aumento da demanda pelo serviço da diarista foi uma forma de se achar uma "saída informal para a informalidade" (p. 12), possibilitando uma nova rota de fuga para os empregadores que não querem ou não podem pagar os direitos trabalhistas das suas contratadas.

Já Harris (2008) situa o problema na crença da ideologia neoliberal "de que os mercados abertos, competitivos e não-regulados, liberados de todas as formas de interferência do Estado, representam o mecanismo ótimo para o desenvolvimento econômico" (p. 14). Não se trata aqui de postular a trabalhadora doméstica como um desses agentes competitivos. Harris credita o crescimento do trabalho doméstico da diarista ao modelo de gestão que "contamina" (palavra minha) as relações de trabalho doméstico, levando a diarização. Como consequência, o neoliberalismo mudou as relações de serviço doméstico suprimindo as obrigações do empregador e deixando a diarista com todo o risco.

Assim sendo, por um lado, a partir do contraste determinado pelo legalmente prescrito, a transição da condição de mensalista para diarista traz consigo a precarização, isto é, a flexibilização do trabalho atrelado à perda de direitos. Sabidamente, no entanto, a maior parte das mensalistas ainda não é registrada. Muitas trabalhadoras que migram para a condição de diaristas, inclusive, justificam que o fizeram porque não tinham carteira assinada. Portanto, não é sobre a configuração real do trabalho doméstico que incide a imagem da precarização. Na configuração real, trabalhadoras passam da condição de mensalistas para diaristas sem que isso implique em perda de direitos, justamente por já não tê-los efetivados, ainda que legalmente os possua. O que se valoriza, portanto, com o termo precarização, é a possibilidade que a recente mudança Constitucional traz, afinal, trabalhadoras podem não ter seus direitos efetivados, mas tem a cobertura legal e podem recorrer à justiça. Nesse 
sentido, os vínculos no interior das residências em que prestam serviço são reveladoras dos mecanismos que tornam as relações de trabalho doméstico opacas ao legalmente prescrito.

\title{
1.2 TRABALHO DOMÉSTICO E RELAÇÕES DE INTERSECCIONALIDADE
}

Em 2014, os serviços domésticos empregavam quase 6,5 milhões de pessoas no Brasil. O total exclusivamente de mulheres era de 5,9 milhões, o que correspondia a $92 \%$ das pessoas ocupadas na atividade no país. Assim sendo, pode-se considerar que só o total de as mulheres que se dedicam aos serviços domésticos remunerados no país gira em torno de $12 \%$ de todos os homens e mulheres empregados na ocupação no mundo. Esse total, segundo a OIT, foi estimado em 52,6 milhões de pessoas em $2010^{23}$.

\begin{abstract}
Basándose en estadísticas oficiales de 117 países y territorios, este informe presenta una nueva estimación del número de trabajadores domésticos en el mundo de 52,6 millones en 2010. Como categoría de trabajo por si sola cuenta con una fuerza de trabajo tan numerosa como la de países como México, Nigeria o Viet Nam. Además, según los datos que proporcionan las estimaciones, se trata de una fuerza de trabajo que ha aumentado en más de 19 millones de trabajadores desde 1995, cuando los trabajadores domésticos en el mundo sumaban 33,2 millones. Ambas cifras son estimaciones prudentes que tal vez subestimen su verdadero alcance, habida cuenta de que en las encuestas de la fuerza de trabajo el recuento de los trabajadores domésticos tiende a ser incompleto Las cifras tampoco incluyen a los trabajadores domésticos de menos de 15 años, que suman 7,4 millones (OIT, 2013) ${ }^{24}$.
\end{abstract}

Das quase seis milhões de mulheres no trabalho doméstico no país em 2014, 0,15\% são amarelas, $0,41 \%$ são indígenas, $14,19 \%$ são pretas, $34,84 \%$ são brancas e $50,40 \%$ são pardas, de acordo com categorias do IBGE (ver tabela 2).

\footnotetext{
${ }^{23}$ Esse número não é consensual. Fontes da própria OIT estimam que o número total de trabalhadores e trabalhadoras domésticas pode chegar a 104 milhões de pessoas (IPEA, 2012, p.3; SANCHES, 2009). Embora não se tenha encontrado dados exclusivamente sobre trabalho doméstico da população feminina no Brasil referente ao censo de 2010, desde 2009 o número absoluto de mulheres nesse serviço tem diminuído, sendo que, em 2011 era de pouco mais de 6,2 milhões mulheres (fonte: microdados PNAD 2008-2014), portanto, no ano anterior deveria ser um número maior que este superando $10 \%$ da população mundial empregada nos serviços domésticos, desde que considerado o total de 52,6 milhões.

${ }^{24}$ Disponível em http://www.ilo.org/wcmsp5/groups/public/---ed_protect/---protrav/---travail/documents/publication/wcms_200965.pdf.
} 
Tabela 2: DISTRIBUIÇÃO RACIAL DE MULHERES NO INTERIOR DE GRUPAMENTOS OCUPACIONAIS (EM \%) - BRASIL ${ }^{25}$

\begin{tabular}{|l|r|r|r|r|r|r|}
\hline \multicolumn{1}{|c|}{ Grupamentos ocupacionais } & indígena & \multicolumn{1}{|c|}{ branca } & preta & amarela & parda & Total \\
\hline Dirigentes em geral & 0,25 & 69,91 & 4,19 & 1,36 & 24,29 & 100 \\
\hline $\begin{array}{l}\text { Profissionais das ciências e das ar- } \\
\text { tes }\end{array}$ & 0,27 & 62,78 & 6,27 & 0,99 & 29,7 & 100 \\
\hline Técnicas de nível médio & 0,31 & 54,68 & 8,53 & 0,64 & 35,84 & 100 \\
\hline $\begin{array}{l}\text { Trabalhadoras de serviços admi- } \\
\text { nistrativos }\end{array}$ & 0,18 & 54,38 & 7,23 & 0,61 & 37,6 & 100 \\
\hline Trabalhadoras dos serviços & 0,42 & 41,07 & 11,86 & 0,5 & 46,14 & 100 \\
\hline $\begin{array}{l}\text { Vendedoras e prestadoras de ser- } \\
\text { viço do comércio }\end{array}$ & 0,24 & 45,81 & 7,72 & 0,5 & 45,74 & 100 \\
\hline Trabalhadoras agrícolas & 1,14 & 35,9 & 8,46 & 0,27 & 54,21 & 100 \\
\hline $\begin{array}{l}\text { Trabalhadoras da produção de bens } \\
\text { e serviços e de reparação e manu- }\end{array}$ & 0,42 & 49,75 & 8,53 & 0,39 & 40,9 & 100 \\
tenção & 0 & 48,25 & 13,17 & 0 & 38,57 & 100 \\
\hline $\begin{array}{l}\text { Membros das forças armadas e au- } \\
\text { xiliares }\end{array}$ & 0 & 84,35 & 0 & 0 & 15,65 & 100 \\
\hline Ocupações maldefinidas & & & & & \\
\hline Trabalhadoras domésticas & $\mathbf{0 , 4 1}$ & $\mathbf{3 4 , 8 4}$ & $\mathbf{1 4 , 1 9}$ & $\mathbf{0 , 1 5}$ & $\mathbf{5 0 , 4}$ & $\mathbf{1 0 0}$ \\
\hline
\end{tabular}

Fonte: microdados PNAD 2014. Elaboração própria.

A tabela acima mostra a composição racial de cada grupamento ocupacional. Limitando a análise aos grupos raciais de mulheres brancas, pretas e pardas, que perfazem 99,05\% das mulheres no mercado de trabalho (indígenas são 0,40\% e amarelas são 0,55\%), o trabalho doméstico é o que conta com o menor percentual de mulheres brancas dentre os grupamentos ocupacionais no mercado de trabalho, $34,84 \%$. Para trabalhadoras pretas, a situação se inverte, sendo a participação delas no trabalho doméstico percentualmente maior do que sua participação nos outros grupamentos, 14,19\%. Quanto às mulheres pardas, o único grupamento que tem uma participação percentual superior a sua, 50,4\%, é o de trabalhadoras agrícolas.

\footnotetext{
${ }^{25}$ A variável "grupamentos ocupacionais", trazia originalmente dez subgrupos, não estando incluído aí "trabalhadoras domésticas". Numa tabulação própria, as trabalhadoras domésticas que estavam dissolvidas entre os outros grupamentos foram reunidas no décimo primeiro subgrupo. Outras variáveis foram preteridas (algumas inclusive já tinham subgrupo específico para "trabalhadoras domésticas") basicamente porque: 1) traziam um desvio padrão maior (o que significa que dentro de um subgrupo existia uma multiplicidade muito grande, por exemplo, um subgrupo denominado "empregado com carteira assinada" de acordo com determinada variável, comportava um espectro muito grande de trabalhadoras agrupando [a partir de outra variável] desde "dirigentes em geral" até "trabalhadores agrícolas"); 2) não trazia a totalidade de trabalhadoras no mercado de trabalho (em algumas variáveis, especialmente, ficam de fora as trabalhadoras rurais).
}

26 A "Relação de códigos de atividade" (anexo IV de metodologia da PNAD, disponível em: http://www.ibge.gov.br/home/estatistica/populacao/trabalhoerendimento/pnad2014/microdados.shtm) apresenta cinco subcategorias para "atividades maldefinidas": atividade maldefinida, biscate (serviço em geral), biscateiro (serviço em geral), faz tudo (serviço em geral), serviço de mandado. 
Esses números não mostram a importância diferenciada dos serviços domésticos para os grupos raciais, já que tal como aparecem acima, estão enviesados pelo tamanho dos grupos. Comparando as distribuições de cada grupo racial em separado no mercado de trabalho, identifica-se o peso que o trabalho doméstico tem na incorporação de cada um deles a este mercado (ver tabela 3).

Tabela 3: PESO DOS GRUPAMENTOS OCUPACIONAIS NA DISTRIBUIÇÃO RACIAL DE MULHERES NO MERCADO DE TRABALHO (EM\%) - BRASIL

\begin{tabular}{|l|r|r|r|r|r|}
\hline \multicolumn{1}{|c|}{ Grupamentos ocupacionais } & indígena & branca & preta & amarela & parda \\
\hline Dirigentes em geral & 2,78 & 6,51 & 2,06 & 11,07 & 2,59 \\
\hline Profissionais das ciências e das artes & 9,09 & 17,69 & 9,33 & 24,25 & 9,58 \\
\hline Técnicas de nível médio & 5,56 & 8,29 & 6,84 & 8,46 & 6,22 \\
\hline Trabalhadoras de serviços administrativos & 6,41 & 16,28 & 11,45 & 16 & 12,88 \\
\hline Trabalhadoras dos serviços & 17,12 & 14,08 & 21,49 & 15,03 & 18,1 \\
\hline $\begin{array}{l}\text { Vendedoras e prestadoras de serviço do comér- } \\
\text { cio }\end{array}$ & 6,87 & 11,14 & 9,92 & 10,65 & 12,73 \\
\hline Trabalhadoras agrícolas & 30,1 & 7,9 & 9,84 & 5,27 & 13,65 \\
\hline $\begin{array}{l}\text { Trabalhadoras da produção de bens e serviços e } \\
\text { de reparação e manutenção }\end{array}$ & 7,9 & 7,79 & 7,06 & 5,36 & 7,33 \\
\hline Membros das forças armadas e auxiliares & 0 & 0,15 & 0,22 & 0 & 0,14 \\
\hline Ocupações maldefinidas & 0 & 0,06 & 0 & 0 & 0,01 \\
\hline Trabalhadoras domésticas & $\mathbf{1 4 , 1 8}$ & $\mathbf{1 0 , 1 2}$ & $\mathbf{2 1 , 7 8}$ & $\mathbf{3 , 9 1}$ & $\mathbf{1 6 , 7 6}$ \\
\hline Total & 100 & 100 & 100 & 100 & 100 \\
\hline
\end{tabular}

Fonte: microdados PNAD 2014. Elaboração própria.

Embora o número absoluto de mulheres brancas seja maior que de pretas, considerando o peso relativo desses dois grupos no mercado de trabalho, de cada 100 mulheres brancas aproximadamente dez são trabalhadoras domésticas, de cada 100 mulheres pardas aproximadamente dezessete estão empregadas nessa atividade e de cada 100 mulheres pretas aproximadamente vinte e duas delas estão nessa ocupação. Os serviços domésticos remunerados respondem pelo maior percentual de mulheres pretas e pelo segundo maior percentual de mulheres pardas no mercado de trabalho.

Esses dados mostram que o trabalho doméstico é feminizado e racializado. Historicamente a figura da "empregada doméstica" (portanto, mensalista como dito na introdução), associada a população negra, tem sido acionada como símbolo de desprestígio social. Alguns pesquisadores enxergam uma mudança de cenário no trabalho de diarista. No entanto, este também se apresenta altamente racializado ${ }^{27}$, como mostra a tabela abaixo.

\footnotetext{
${ }^{27}$ Fraga chega à conclusão diferente (2010, p. 89-92). Ele se limita a analisar o percentual de mulheres de cada grupo racial na totalidade do trabalho doméstico (como na Tabela 2), que traz dimensões importantes, mas não se pode ficar limitado a esse método). Assim, se num lugar imaginário tivermos uma população branca de 10.000 pessoas e negra de 1.000 pessoas, supondo que 2.000 brancas e todas as 1.000 pessoas negras façam
} 
Tabela 4: VARIAÇÃO DA PARTICIPAÇÃO RACIAL NO TRABALHO DOMÉSTICO DE DIARISTA E MENSAL ENTRE 2002 E 2014 (EM\%) - BRASIL

\begin{tabular}{|l|r|r|r|r|r|r|r|}
\hline \multirow{2}{*}{ Cor/raça } & \multicolumn{2}{|c|}{2002} & \multicolumn{2}{c|}{2014} & \multicolumn{2}{c|}{ variação percentual 2002- } \\
& diarista & mensalista & diarista & mensalista & \multicolumn{1}{c|}{ diarista } & \multicolumn{1}{c|}{ mensalista } \\
\hline Indígenas & 0.26 & 0.25 & 0.57 & 0.34 & 119.23 & 36.00 \\
\hline Branca & 45.92 & 43.12 & 37.93 & 33.44 & -17.40 & -22.45 \\
\hline Preta & 10.95 & 10.02 & 14.18 & 14.2 & 29.50 & 41.72 \\
\hline Amarela & 0.09 & 0.17 & 0.21 & 0.13 & 133.33 & -23.53 \\
\hline Parda & 42.78 & 46.44 & 47.11 & 51.9 & 10.12 & 11.76 \\
\hline TOTAL & 100 & 100 & 100 & 100 & & \\
\hline
\end{tabular}

Fonte: microdados PNAD 2014. Elaboração própria.

Limitando às mulheres brancas, pretas e pardas, a tabela acima mostra que o trabalho doméstico de diarista tem arregimentado principalmente mulheres negras (pretas e pardas, de acordo com categorias do IBGE) entre 2002 e 2014. O percentual de mulheres brancas excede o de negras devido ao tamanho da população desses grupos raciais, mas a importância que as diárias têm para mulheres negras é maior do que para brancas. De cada 100 mulheres brancas, 3,68 é diarista; de cada 100 pretas 7,98 são diaristas e de cada 100 pardas, 5,54 são diaristas. Portando, além de o seguimento do trabalho doméstico prestado na modalidade diária ser igualmente racializado, conta com altas taxas de incorporação de mulheres negras ao passo que entre mulheres brancas a taxa de incorporação decresce.

Esse quadro mostra como o conceito de gênero é insuficiente para dar conta das manifestações que se verificam nesse trabalho sem a conexão com raça. O trabalho doméstico configura-se como ocupação genderizada e racializada. Saffioti (2009), tratando de combinações de características que agem negativamente sobre o indivíduo, considerando não só de gênero e raça, mas também de classe social, mostra que "não se trata de somar racismo + gênero + classe social, mas de perceber a realidade compósita e nova que resulta desta fusão" (: 19). Cada um desses termos tem determinações distintas que nem sequer apontam obrigatoriamente para a mesma direção. Portanto, não se deve avaliar essas opressões em termos de adição. Não se é duplamente ou triplamente discriminada. Estas variáveis devem ser percebidas qualitativamente, não quantitativamente. Defende ela que essas características,

trabalhos domésticos, o método de Fraga o impediria de perceber a profissão como racializada porque no seu cômputo resultaria em $66 \%$ de brancas e $33 \%$ de negras nessa atividade. 
quando combinadas passam a apresentar uma dinâmica particular que não apresentavam separadamente ${ }^{28}$.

Ainda explorando essa questão, Collins (2016) também coloca ênfase na "natureza interligada da opressão", assinalando que esta tem sido a tônica do pensamento feminista negro. Citando Barbara Smith (1983), Collins pontua que a simultaneidade de opressão é “o cerne de uma compreensão feminista negra da realidade política" (SMITH, 1983, apud COLLINS, 2016, p. 107). O centro dessa abordagem aponta para o fato de que as opressões baseadas na raça, gênero, classe social (entre outros tipos) são experimentados simultaneamente por mulheres negras e por isso formam uma matriz de dominação que traz como implicação a mudança de "uma abordagem que tinha como objetivo explicar os elementos de raça, gênero ou opressão de classe, para outra que pretende determinar quais são os elos entre esses sistemas" (p. 108). Kimberlé Crenshaw, a partir do conceito de interseccionalidade, traz outras dimensões sobre a simultaneidade de opressões.

\begin{abstract}
A interseccionalidade sugere que, na verdade, nem sempre lidamos com grupos distintos de pessoas e sim com grupos sobrepostos. Assim, ao sobrepormos o grupo das mulheres com o das pessoas negras, o das pessoas pobres e também o das mulheres que sofrem discriminação por conta da sua idade ou por serem portadoras de alguma deficiência, vemos que as que se encontram no centro - e acredito que isso não ocorre por acaso - são as mulheres de pele mais escura e também as que tendem a ser as mais excluídas das práticas tradicionais de direitos civis e humanos. (CRENSHAW, 2004, p. 10).
\end{abstract}

Ao trazer a dimensão dos direitos civis e humanos, Crenshaw dá um direcionamento possível para se investigar como a opressão interseccionada age sobre a vida de mulheres no centro da matriz de dominação apontada por Collins, na medida em que aponta para a institucionalização da matriz de dominação que exclui quem se encontra no centro de cruzamentos formados por raça, gênero, classe social, bem como outras categorias desvalorizadoras. Assim, o trabalho doméstico, que tem como marca diacrítica a desigualdade de direitos, arregimenta principalmente mulheres com uma experiência racializada de gênero, articulando "eixos estruturantes da matriz da desigualdade social no Brasil" (ABRAMO, 2006).

Mendoza (2010), resgata o conceito de colonialidade do poder, presente em Quijano, segundo o qual "raça", um construto derivado da colonização, passa a ser um dos vetores

\footnotetext{
${ }^{28}$ Sobre outras autoras no país que trabalharam com conceitos que dialogam com a ideia presente ver Castro (1992) e Hirata (2014).
} 
que organizam a estrutura social de forma decisiva em âmbito planetário, codificando a divisão do trabalho entre escravidão e trabalho livre, reservando o trabalho livre e assalariado aos homens brancos (p. 25). No entanto, aponta que Quijano não levou a discussão sobre gênero tão longe quando o fez com a de raça, desprezando que a reorganização de gênero também foi decisiva para a estrutura de poder que se desenvolveu posteriormente, que associava o trabalho livre ao homem branco. Ao fazer essa ressalva, Mendoza introduz o conceito de colonialidade de gênero, historicizando a sua montagem e apontando a utilidade administrativa de sua integração nas novas terras.

Las mujeres de estas partes del mundo colonizado no sólo fueron racializadas sino que al mismo tiempo fueron reinventadas como "mujeres" de acuerdo a códigos y principios discriminatorios de género occidentales. La colonización creó las circunstancias históricas para que las mujeres africanas e indígenas de Norte América perdieran las relaciones relativamente igualitarias que tenían con los hombres de sus sociedades y cayeran no sólo bajo el dominio de los hombres colonizadores sino también bajo el de los hombres colonizados. La subordinación de género fue el precio que los hombres colonizados tranzaron para conservar cierto control sobre sus sociedades. Es esta transacción de los hombres colonizados con los hombres colonizadores lo que explica, según Lugones, la indiferencia hacia el sufrimiento de las mujeres del tercer mundo que los hombres, incluso los hombres de izquierda del tercer mundo, manifiestan con su silencio alrededor de la violencia contra las mujeres en la actualidad. Esta confabulación de los hombres colonizados con sus colonizadores es lo que impide construir lazos fuertes de solidaridad entre las mujeres y los hombres del tercer mundo en procesos de liberación. Pero ignorar la historicidad y colonialidad de género también ciega a las mujeres blancas de Occidente, a quienes igualmente les ha costado reconocer la interseccionalidad de raza y género, y su propia complicidad en los procesos de colonización y dominación capitalista (MENDOZA, 2010, p. 23).

Essa negociação de que fala Mendoza mostra como operam as variáveis de gênero e raça na estruturação de lugares sociais diferenciados em prestígio. A mulher negra não só ocupa o espaço doméstico reservado às mulheres, mas mesmo quando está trabalhando executa as mesmas funções que realiza na própria casa. Não é ocasional que na distribuição das mulheres brancas no mercado de trabalho a posição que elas menos ocupam seja como trabalhadoras domésticas e que o quadro verificado para trabalhadoras negras seja o inverso. Além de a racialização levar mulheres a estarem sempre presas ao doméstico mesmo quando saem para trabalhar, em épocas em que mulheres brancas e "honestas" não trabalhavam, já incumbia negras assaltadas pela pauperização do trabalho doméstico, ou, como acontece atualmente, as levam a trabalhar muito jovens comprometendo sua formação e as possibili- 
dades profissionais que terão no futuro. Desse modo, as representações que estruturam hierarquias opressivas não se materializam igualmente em todos os corpos, muito embora ela possa se mostrar interligadas em alguns deles, trazendo como consequência modos diferenciados como se lida com a opressão e de transferir parte do seu peso a outros:

Como grupo, as mulheres negras estão em uma posição incomum nesta sociedade, pois não só estamos coletivamente na parte inferior da hierarquia ocupacional, mas nossa condição social geral é inferior à de qualquer outro grupo. Ocupando essa posição, suportamos o fardo da opressão machista, racista e classista. Ao mesmo tempo, somos o grupo que não foi socializado para assumir o papel de explorador/opressor, no sentido de que não nos permitem ter qualquer "outro" não institucionalizado que possamos explorar ou oprimir. (As crianças não representam um outro institucionalizado, embora possam ser oprimidas pelos pais.) As mulheres brancas e os homens negros têm as duas condições. Podem agir como opressores (as) ou ser oprimidos (as). Os homens negros podem ser vitimados pelo racismo, mas o sexismo lhes permite atuar como exploradores e opressores das mulheres. As mulheres brancas podem ser vitimadas pelo sexismo, mas o racismo lhes permite atuar como exploradoras e opressoras de pessoas negras. Ambos os grupos têm liderado os movimentos de libertação que favorecem seus interesses e apoiam a contínua opressão de outros grupos. O sexismo masculino negro prejudicou a luta para erradicar o racismo, assim como o racismo feminino branco prejudica a luta feminista. Enquanto definirem a libertação como a obtenção de igualdade social com os homens brancos da classe dominante, esses dois grupos, ou qualquer outro, terão um grande interesse na exploração e opressão continuada de outras pessoas (hooks ${ }^{29}, 2015$, p. 207-208).

É esse quadro que articula classe social, raça e gênero formando a matriz de dominação nas quais trabalhadoras domésticas estão inseridas. Se, inicialmente, noções de raça e gênero, foram mobilizadas na definição de posições na estrutura hierárquica colonial, essas posições apresentavam (como ainda apresentam) graus relativos de opressão que permitem a alguns oprimidos atuarem como opressores. No entanto, quanto maior o número de vetores se interseccionam na matriz de dominação, mais essa possibilidade é vedada. A própria possibilidade de "passar" a opressão adiante, reitera (pela repetição, que implica em apontar, novamente e novamente, o lugar subalterno do outro), ao longo do tempo, a articulação entre posições desvalorizadas e pessoas subestimadas. Portanto, isso se acentua nos níveis (e a medida) em que os tipos de opressão se mostram mais interligados.

\footnotetext{
29 "bell hooks" é escrito com caixa baixa. Nascida Gloria Jean Watkins, a autora adotou o nome da avó, Bell Blair Hooks. "Ela adotou o nome de sua avó como um pseudônimo, porque sua avó 'era conhecida por sua língua ágil e ousada, que [hooks] muito admirava'. Ela colocou o nome em letras minúsculas 'para distinguir [-se de] sua avó'. Ela disse que a escrita em caixa-baixa não convencional de seu nome significa que o mais importante são suas palavras: a 'substância dos livros , não quem eu sou". Disponível em http://www.barenose.com/be stumble/2015/09/25/remember-the-ladies-bell-hooks/.
} 
Nesse sentido, cabe voltar ao trabalho doméstico para alicerçar as noções acima. A pesquisa de Sorj (2013), anteriormente referida, que trata do papel que as arenas de cuidado têm na incorporação de mulheres ao mercado de trabalho, constata que "para os homens, a posição na distribuição da renda é quase indiferente, sobressaindo a influência quase que absoluta de sua identidade de gênero, masculina, fortemente construída pela distância que mantem e preservam em face da esfera doméstica" (p. 485) ao passo que, para mulheres, classe social se tornou decisivo na quantidade de horas que se dedicam a essa esfera. O que está em questão aí é o trabalho doméstico na própria residência, ao passo que raça se torna indispensável para se compreender o trabalho doméstico executado na casa do outro.

As mulheres conquistaram espaço (e continuam a conquistar) no mercado de trabalho não-doméstico e se desvencilharam da esfera reprodutiva do lar devido ao fato de poderem encarregar outras mulheres, social, racial/etnicamente diferentes, pelas funções que anteriormente tinham sido transferidas a elas (ÁVILA, 2010; BRITES, 2007; BRUSCHINI; LOMBARDI, 2000; HIRATA; KERGOAT, 2007). Passar as incumbências do trabalho doméstico adiante não é exclusividade no país (COLEN, 1995; GLENN, 1992; GUTIÉRREZRODRÍGUEZ, 2013; hooks, 2015). Noções de gênero e raciais operam essa transferência, levando homens e mulheres a "passarem" o problema adiante, relegando a posição desvalorizada a pessoas subestimadas. 


\section{ENTREVISTAS ${ }^{30}$}

É comum que em trabalhos que se utilizam da observação participante haja uma descrição densa do que foi visto em campo. Infelizmente, em trabalhos com entrevistas não se tem o mesmo habito de revelar os bastidores, restando pouco espaço para contextualizações e possiblidade de contradições. Por essa razão, optou-se por deixar as entrevistas que, no entanto, estão com edições que colocam o texto em ordem linear, suprimem partes repetidas e perguntas que não "funcionaram". Entende-se como "não funcionar", perguntas cujas respostas não deram margem para se perceber sua profundidade na vida das entrevistadas. Apenas como exemplo, todas as trabalhadoras, com exceção de Ângela e Cleide, disseram "gostar" do trabalho. As razões são muitas, sem intenção de esgotar todas as motivações que manifestaram, Antônia fala sobre a relação de confiança e do tratamento que recebe no trabalho. Érica fala da ajuda da patroa e dos fortes vínculos nutridos com uma criança de quem tomava conta. Zélia fala segurança das relações empregatícias. Flávia fala de confiança, mas em perspectiva muito distinta da de Antônia. Celina atrela o trabalho ao sentimento de amizade e a realização pessoal. Cecília, por sua vez, também disse gostar do trabalho, mas não disse qualquer coisa que possibilitasse perceber de que forma esse "gostar" se manifesta, razão pela qual essa parte da fala foi suprimida da edição.

Foram entrevistadas três mulheres no Plano Piloto e cinco nas Regiões Administrativas do Distrito Federal. Todas com experiência como diarista e mensalista, com exceção de Celina que trabalhou apenas como diarista. Todas as entrevistas foram gravadas, com exceção da feita com Cecília. Apenas para situar as entrevistadas, duas delas, Flávia e Zélia, além de trabalharem como diaristas, conciliavam essa função com trabalho não-doméstico registrado. Outras duas estão às voltas com diferentes vínculos: uma, Cecília, que é diarista e tem sua semana de trabalho completa vai dispensar alguns clientes ${ }^{31}$ para trabalhar numa residência como mensalista registrada; a outra, Cleide, que gostaria de ser apenas diarista serviço que faz apenas nos finais de semana - e é contratada esporadicamente para tomar conta de crianças no período noturno, tem receio de deixar o emprego atual para se tornar exclusivamente diarista e não conseguir clientes estáveis. Outras três entrevistadas, Antônia, Ângela e Celina, trabalhavam "apenas" como diaristas. O que as diferencia de Cecília é que

\footnotetext{
${ }^{30}$ Os nomes das entrevistadas e dos personagens são fictícios.

${ }^{31}$ Cliente é um termo usado por algumas diaristas para se referirem às pessoas que contratam seus serviços.
} 
não tem qualquer intenção de deixar as diárias. Ângela e Celina são aposentadas - Celina, a única entrevistada que nunca trabalhou como mensalista, só como diarista, presta serviço hoje numa única residência e, ao que tudo indica, tanto por parte dela quanto da patroa, o vínculo empregatício se mantém por razões que passam ao largo da mercantilização dos serviços domésticos. Por último, Érica, embora faça diárias todos os fins de semana para uma família, não tem mais essa atividade como seu principal trabalho remunerado como no passado. O que a levou a fazer tal mudança foi a família.

Em comum, todas são de outros estados, o que revela uma especificidade de Brasília. De um lado, trabalhadoras domésticas formam o grupamento com maior percentual de mulheres migrantes no mercado de trabalho: 54,39\% delas são migrantes. De outro lado, esta é a unidade da federação com maior percentual de trabalhadoras domésticas migrantes (ver página 81). Assim, a migração não é simplesmente mais um elemento a ser considerado no trabalho doméstico, mas um configurador do trabalho doméstico no Distrito Federal.

Além do alto percentual de migrantes, mulheres que acumulavam vários trabalhos foi outro fator inesperado encontrado nas entrevistas. O número de trabalhadoras domésticas que têm outros trabalhos, de acordo com a PNAD, é de pouco mais de $2 \%$ no país. No Distrito Federal, não chega a 1,5\%. Apesar de pouco representativas nesse universo, a situação de mulheres com vários trabalhos, em larga medida, é semelhante à situação de diaristas que trabalham em vários lugares (não importa em quantas residências uma diarista trabalhe, será sempre um trabalho). Contatar essas mulheres foi importante pelo fato de terem trazido perspectivas que recolocaram a importância do rendimento no trabalho doméstico da diarista e evidenciaram estratégias que mostraram que a problemática pertinente ao rendimento reside na insegurança vivida por diaristas pela completa falta de direitos. Assim, o rendimento só pode ser avaliado prontamente como algo positivo ao custo de obliterar as extremas inseguranças vividas que levam as poucas que apresentam rendimento satisfatoriamente maior ao excesso de trabalho.

Com ênfases e estratégias adotadas diferentes, a esfera do direito tem papel central no modo como se configurou a vida de cinco dentre as oito entrevistadas: Érica, Cecília, Zélia, Flávia e, a contrapelo, Ângela que se tornou diarista por não ter qualquer direito na casa onde trabalhava como residente. Celina e Ângela também são aposentadas. Posto que, em face da literatura existente sobre trabalho doméstico, abordar questões referentes à direitos exige que se aborde também relacionamentos afetivos construídos nesse âmbito, Ângela 
não fala sobre o relacionamento com os patrões. Já Celina deixa claro vínculos que extrapolam o meramente profissional. Antônia, por outro lado, deixa claro vínculos que, na teoria são vistos como práticas políticas, mais ou menos significando a instrumentalização da relação pessoal com vistas a confrontar situações de vulnerabilidade de modo mais eficaz que a mera cobertura legal poderia fazer. Antônia, no entanto, não entende (apenas) dessa maneira. Ela deixa claro: "não é por dar as coisas", é pelo significado de confiança que o ato traz. Por último, Cleide, gostaria de ser apenas diarista, mas tem medo da situação de instabilidade anteriormente citada. Mas não é só por isso que não deixa o atual emprego, também contam as relações construídas e o sentimento de dever, de lealdade e poder estar perto dos filhos.

\section{Quadro 4: TRABALHADORAS DOMÉSTICAS ENTREVISTADAS}

\begin{tabular}{|l|l|l|l|l|l|l|}
\hline Nome & $\begin{array}{l}\text { naturali- } \\
\text { dade }\end{array}$ & idade & $\begin{array}{l}\text { tempo } \\
\text { em Bra- } \\
\text { sília }\end{array}$ & residência & trabalhos anteriores & $\begin{array}{l}\text { localidade onde } \\
\text { presta serviço }\end{array}$ \\
\hline Antônia & $\begin{array}{l}\text { Petrolina / } \\
\text { GO }\end{array}$ & 56 & 20 anos & Ceilândia & mensalista (r) e diarista & $\begin{array}{l}\text { 1 em Samambaia, 7 } \\
\text { em Ceilância, }\end{array}$ \\
\hline Érica & Altos / PI & 38 & 23 anos & Sobradinho & $\begin{array}{l}\text { mensalista (r), faxineira } \\
\text { terceirizada e diarista }\end{array}$ & $\begin{array}{l}\text { Plano Piloto e } \\
\text { Guará }\end{array}$ \\
\hline Cleide & $\begin{array}{l}\text { Sta. Quité- } \\
\text { ria / CE }\end{array}$ & 47 & 12 anos & $\begin{array}{l}\text { Plano Pi- } \\
\text { loto }\end{array}$ & $\begin{array}{l}\text { lojista } \\
\text { mensalista (nr) e diarista }\end{array}$ & Plano Piloto \\
\hline Cecília & $\begin{array}{l}\text { Felizardo / } \\
\text { CE }\end{array}$ & 35 & 18 anos & $\begin{array}{l}\text { Plano Pi- } \\
\text { loto }\end{array}$ & diarista e mensalista (nr) & Plano Piloto \\
\hline Ângela & $\begin{array}{l}\text { Giubués / } \\
\text { PI }\end{array}$ & 65 & 37 anos & $\begin{array}{l}\text { Recanto } \\
\text { das Emas }\end{array}$ & $\begin{array}{l}\text { lavradora, mensalista (r) e } \\
\text { diarista }\end{array}$ & Recanto das Emas \\
\hline Zélia & $\begin{array}{l}\text { São Fran- } \\
\text { cisco / MG }\end{array}$ & 48 & 30 anos & $\begin{array}{l}\text { Plano Pi- } \\
\text { loto }\end{array}$ & $\begin{array}{l}\text { mensalista (r), } \\
\text { copeira terceirizada e } \\
\text { diarista }\end{array}$ & Plano Piloto \\
\hline Flávia & $\begin{array}{l}\text { Raul Soa- } \\
\text { res / MG }\end{array}$ & 48 & 35 anos & Sobradinho & $\begin{array}{l}\text { mensalista (nr), auxiliar } \\
\text { odontologia e diarista }\end{array}$ & Plano Piloto \\
\hline Celina & $\begin{array}{l}\text { Raul Soa- } \\
\text { res / MG }\end{array}$ & 74 & 31 anos & Planaltina & lavradora e diarista & Plano Piloto \\
\hline
\end{tabular}

Legenda: r: residente; nr: não residente.

\subsection{ANTÔNIA}

Felipe, um amigo estudante da Universidade de Brasília, me levou até a casa de sua mãe, Antônia, na Ceilândia, num domingo, onde ocorreu a entrevista. Antônia nasceu em Petrolina, Goiás, perto de Goiânia. Morou em outras cidades do estado e também no Pará, onde era dona de casa. Filha de pais lavradores, tem sete irmãos, uma delas também diarista. Evangélica da Assembleia de Deus, Antônia gosta de sair só para ir à Igreja.

\footnotetext{
${ }^{32}$ Cleide tinha banca em que vendia roupa na feira.
} 
Separada do marido, mudou-se sozinha para Brasília. Na época, não trouxe os fillhos consigo: a mãe, no estado vizinho, tomava conta deles. Anos mais tarde, depois de casada novamente e trabalhando como diarista, manda buscar os filhos para morar consigo. Quando chegou em Brasília, já estava tudo acertado para trabalhar em casa de família. Antônia começou trabalhando como mensalista residente, não ficou muito tempo no primeiro trabalho.

Dentre todos os empregos como mensalista, o que mais gostou foi da segunda família para quem trabalhou depois de ter chegado no Distrito Federal. Trabalhava registrada e também dormia no serviço de segunda à sexta-feira. Como ganhava pouco, vendia cerveja na rodoviária para completar o orçamento. A patroa a ajudava comprando mais barato para Antônia revender e descontava nos pagamentos.

\begin{abstract}
Gostava deles por causa do modo de eles me tratar. Não é por dar as coisas. Porque às vezes dizem que uma pessoa é boa de te dar as coisas. Eu gostava deles porque eles me serviam na minha necessidade. Então, tudo que eu precisava, eles não me davam, mas arrumavam para mim. Tudo que eu falava para eles, estavam prontos a me servir. [Quando] eu precisava de um adiantamento de um dinheiro, [de] comprar alguma coisa para mim, [eles] me ajudavam. Nessa época eu não tinha meus filhos aqui. Eu pedia ajuda para os meus irmãos. Nessa época, como eu ganhava pouco, aí ela me arrumava e eu vendia cerveja na rodoviária para completar o meu... E ela ajudava, ela comprava para eu vender. Mas dessas casas que eu trabalhei todos foram pessoas muito boas. Me tratavam bem, não me discriminavam. Porque você trabalha para as pessoas e as pessoas te discriminam.
\end{abstract}

O patrão saia às $6 \mathrm{~h}$ da manhã e voltava às $8 \mathrm{~h}$ da noite. Então, tinha que servir café ou lanche quando ele chegava. "Eu ainda tava aqui sozinha. Tava a disposição todo o tempo", diz. A cerveja, vendia no final de semana. No sábado, trabalhava até meio dia e ia embora para a casa de uma amiga. Se somado todo o tempo em que trabalhou de mensalista, acredita que totaliza algo em torno de cinco anos.

Trabalhou em 5 casas como mensalista em intervalos variáveis que vão de poucos meses a três anos no máximo. Em todas as casas tinha duas ou três crianças, com exceção de uma em que só havia uma senhora. Relações de confiança e ajuda tais como a construída com essa família foram constantes na sua vida de trabalho. "Todas as casas que trabalhei todos me tratavam muito bem", diz Antônia

Na época que eu trabalhava como mensalista, não era como é agora. [O empregador] assinava carteira se quisesse. Não tinha segurança nenhuma. Agora, sim, tem segurança, né? A pessoa que tá trabalhando tem até seguro-desemprego, mas naquela época não tinha. [A gente] trabalhava. [A gente] recebia. [Quando o patrão] mandava embora, pagava o que queria. [A gente] não tinha carteira assinada, não tinha nada. Agora, sim, hoje tá bom. A pessoa que trabalha hoje tem seguro-desemprego, férias, décimo terceiro; mas nessa época que eu tava [como mensalista] 
não tinha nada. Hoje como diarista, não tenho segurança nenhuma, não recebo nada, não tenho direito a nada. Eu não tenho direito a décimo terceiro, eu não tenho direito a aviso, eu não..., a nada. Eu não tenho o benefício de nada. As pessoas me dão no final de ano porque eles querem, mas eu não tenho direito a receber nada. Como esses que eu trabalho é gente de muitos anos, no fim do ano, eles me dão mais uma diária, todo mundo me dá. Não sei se é combinado (risos), mas eles me dão. Agora se eu for numa casa três vezes por semana, naquela casa, a pessoa tem que assinar minha carteira. Mas do jeito que eu trabalho não tenho direito a nada. Se acontecer alguma coisa comigo, eles não têm responsabilidade sobre mim. Agora, na época que eu trabalhava por mês, trabalhava, saía, não tinha nada. Não recebia nada. Agora, hoje tá muito bom. Por isso que hoje em dia todo mundo tá querendo uma diarista, por que fica mais barato. Você contrata, a pessoa vai lá, faz o serviço, você pagou, você não tem vínculo nenhum com aquela pessoa. Deixou lá o dinheiro dela e o dinheiro da passagem, você não tem mais despesa com diarista.

Antônia saiu do último trabalho de mensalista porque "vai indo, cansa, né?"; sem mais. A vizinha foi a primeira pessoa para quem trabalhou como diarista. Na época, estava desempregada e a vizinha a convidou para limpar sua casa. Gostou tanto que arrumou outros clientes para Antônia.

Em toda sua vida como diarista, houve períodos em que trabalhou até nos fins de semana para manter o filho na faculdade, fazendo faxinas que lhe rendiam $\mathrm{R} \$ 120,00, \mathrm{R} \$$ 130,00 por casa. Dependendo do lugar, não do tamanho da casa, o valor podia ficar entre R\$ 80,00 e R \$ 100,00. “Hoje em dia eu tenho uns oito clientes. Não trabalho muito, mais. Não tenho mais bebê na faculdade. Já não preciso trabalhar muito. Mas de trabalhar como já trabalhei..." Apenas uma de suas clientes mora em Samambaia, as outras sete são da Ceilândia. Não trabalha nas segundas, nem aos sábados e domingos.

Antônia trabalha a cinco, seis anos nas casas em que presta serviço atualmente. Nem vê as pessoas que a empregam. Ela já tem a chave dos lugares que faxina. Quando chega seus empregadores e empregadoras já saíram para trabalhar, deixando-lhe o dinheiro da diária em cima da mesa.

Hoje tá melhor. É melhor chegar e não ver ninguém. Não tem ninguém para me incomodar, nem eu incomodo ninguém (...). Chego lá, faço o meu serviço direitinho. Se eles têm uma reclamação, deixam escrito ou, então, me ligam e a gente não desgasta vendo um ao outro. Hoje em dia o pessoal é muito ocupado, não tem tempo. Então, querem alguém de confiança para fazer o serviço.

Antônia acrescenta: "eu gosto de fazer o que eu faço, do meu trabalho... Eu gosto... Eu faço aquilo que eu gosto, que é de limpar, de cuidar. Faço com amor.... Eu só limpo. Nas casas em que trabalho como diarista me trataram muito bem, graças a Deus”. 
Antônia deixa claro que não se pode reputar a procura que está havendo hoje em dia por diaristas a uma única causa. Se anteriormente mencionou o fato de que fica mais barato para o empregador contratar a diarista, também leva em conta questões pautadas por representações sobre o quão ocupadas as pessoas são hoje em dia.

Tem gente que vai só para passar [roupa]. Igual, eu só limpo, eu não faço outra coisa. Só limpo. Tem gente que paga para pessoa ir lá só para cozinhar. Faz a comida para semana toda. Tem uma pessoa que você contrata só para organizar suas coisas. Hoje em dia tem até esse tipo de serviço. Você me contrata e eu vou lá organizar os seus armários. Hoje em dia ninguém tem tempo. Tem pessoas que ganham a vida de fazer compra no mercado para os outros, para passear com cachorro. Você tem um cachorrinho, você não tem tempo de passear com ele, você tem que contratar alguém. Hoje em dia, tem para tudo. Eu vou lá e limpo a casa. Outra vai passar. Outra já vai para fazer a comida, outra vai para passear com o cachorro.

Os novos tempos mudaram o tipo e serviço e trouxe razões pelas quais passou a pre-

ferir o trabalho da diarista, mas não modificaram as relações que Antônia tem com os patrões, que não são distintas das que cultivava como mensalista residente.

Se eu precisar de ajuda, é só ligar que eles me ajudam. Você entende o tipo de ajuda, né? Eu estando doente, [e] falar "preciso disso", eles me ajudam. Se preocupam comigo. Já aconteceu e acontece quase direto. Se eu precisar de comprar uma coisa para casa, eles tiram no cartão para mim. Agora mesmo fiz uma reforma na casa e tenho um patrão que tem loja de material. Ele me cedeu todos os materiais que eu precisava e a gente vai descontando. Fez uma diária hoje. Eu vou toda semana. Aí desconta metade. Às vezes precisa comprar alguma coisa: 'fulano, compra isso no seu cartão para mim". A patroa vai e compra. Tem patrão que compra até $R \$ 4, R \$ 5$ mil no cartão. Já confia na gente. Esses dias mesmo queria comprar uma geladeira nova e uma televisão - você sabe que tudo é caro. Liguei para patroa. A patroa comprou quase cinco mil no cartão dela. Então, confia na gente, né? É uma forma de confiar. Tenho meus filhos, meu filho estudava, precisava de comprar alguma coisa, vou lá e corro: "Oh fulano, compra isso no seu cartão!" É na hora. Às vezes eu nem vou na loja. Eles só ligam, falo o que eu quero, compram e ainda vêm deixar na minha porta. Então, eu não sinto como uma... Para mim, eles são a minha família. Porque se eu preciso de médico me levam no hospital particular. Tem patrão que me leva para consultar em hospital particular. Então, eu considero eles como minha família. Todos eles. Eu tenho cliente que tem farmácia, preciso de remédio eles me trazem na porta. Às vezes não me cobram aquele remédio. Todos que eu trabalho, se eu ligar e precisar é na hora. É o ditado: uma mão lava a outra. Eu ajudo eles e eles me ajudam. Eu tenho uma neta. Negócio de vestuário, essas coisas eu não compro [para ela]. Eles dão tudo para minha neta. Para mim, eles não..., não tenho o que dizer deles. Não sei se é pelo tempo que eu trabalho, a minha confiança. Eu tenho um lugar [em que trabalho] que eles mexem com muito dinheiro. Eu fico lá, não mexo com nada deles. Eu acho que é isso também. Já tem aquela confiança. Já pensou você sair e deixar sua casa.... Tem lugar, igual a Raquel, viajou, roubaram a casa dela e quem foi lá e conferiu o que roubou foi eu. É pessoa que confia na gente. 
Em alguns lugares Antônia trabalha de 7h ou 7:30h às 17h. Em apartamentos pequenos às 14h, 15h já está em casa.

\begin{abstract}
Eu vou para uma casa grande, tem muito serviço. Chego lá eu lavo o banheiro... O serviço de uma diarista sabe o que que é? Lavar um banheiro, limpar parede, limpar janela, o serviço pesado da casa, organizar as coisas. Só não faz comida. De vez em quando passa [roupa], mas o trabalho mesmo é só limpeza. A limpeza tem que fazer geral. E nesses lugares que eu faço, tem lugar que eu vou de quinze em quinze dias. E quando eu vou, tem que deixar tudo limpinho, senão eles não gostam.
\end{abstract}

Antônia reconhece que outras trabalhadoras domésticas nem sempre tem relações tão boas com empregadores quanto as que conseguiu cultivar. Lembra-se da história de uma amiga que trabalha para uma policial civil, que lhe agredia. Pondera que, por outro lado, "muitas empregadas aprontam". Sobre os próprios momentos ruins no trabalho doméstico, lembra de numa única ocasião em que foi tratada mal.

\footnotetext{
A pessoa vê que tratam mal ali e não volta mais. Nesse lugar não davam comida. Eles comiam, mas não davam. Tem lugar aí que separam até a comida. Nessa casa que eu fiz essa diária, davam só o café: café puro e leite. Ainda fui uns dias porque, quando você tá precisando, né?
}

Hoje, nos lugares onde trabalha hoje, deixam o dinheiro para comprar o almoço quando fica sozinha. Quando há alguém além de Antônia, não compra comida: senta-se à mesa com a pessoa que está em casa para comer.

Antônia paga contribuição por conta própria. Mas não vai se aposentar por enquanto. "Todo ano penso em parar, mas acho que vou mais uns anos. Tô esperando esse bebê [o filho que estava no cômodo contíguo] me aposentar".

Relembra que tudo o que conseguiu foi com o seu trabalho, inclusive a realização de ver o filho formado. "Meu filho, dos irmãos é o primeiro formado e eu gosto do que faço". Mas tarde lembra que na família toda existem, além do filho, outros três que fizeram o curso superior. Quando fala dos formados da família, Antônia não discorre sobre todos; seleciona o filho que faz pós-graduação na UnB e um primo juiz federal. Assim, na forma como ela compõe esse grupo do qual quer falar, ela deixa claro a sua compreensão do status do filho, permitindo entender o que significa para ela ter um filho numa importante universidade. Mais que isso, não descuida da importância do seu papel nesse processo, tornando materialmente possível que isso pudesse acontecer. Agora sonha em ver o filho passar em concurso público e ver o outro filho, que mora em Goiânia e trabalha em um mercado, estudando. 


\section{2 ÉRICA}

Érica é uma amiga que trabalha no setor de limpeza e conservação da Universidade de Brasília. Jamais passara pela minha cabeça incluí-la entre as entrevistadas desta pesquisa até me contar como conseguiu se inserir com êxito no trabalho doméstico de diarista e, depois, decidiu abandoná-lo para trabalhar para uma empresa que lhe pagava muito menos do que ganhava como diarista. Como isso questionava a premissas fundamentais presentes neste trabalho, decidi incorporar sua história nesta dissertação. A entrevistei no campus da Universidade de Brasília no Plano Piloto em dois dias logo depois do almoço. Natural de Altos, Piauí, foi criada no Maranhão, em Caxias, há uma hora de viagem de Teresina.

O pai era garimpeiro, “conservador”, diz. Quando a mãe se separou, ele foi embora para o garimpo e desapareceu. Depois de vinte anos, quando Érica já tinha tido seu primeiro filho, na época com um ano e meio mais ou menos, reviu o pai por um breve período. O pai reapareceu apenas para tentar lhe arrumar um casamento. Queria que a filha se casasse com um militar aposentado. Depois da recusa de Érica, o pai desapareceu novamente. Foi embora para São Paulo e não se soube mais dele.

Quando Érica mudou-se para o chamado “entorno ${ }^{336 ، ~ d e ~ B r a s i ́ l i a ~ e s t a v a ~ g r a ́ v i d a, ~ f u-~}$ gindo da mãe. Ainda em Caxias, encontrou, por acaso, Lourdes, que estava procurando uma pessoa para levar consigo para trabalhar na sua casa em Valparaíso. Érica, então, mudou-se já com trabalho arrumado. Morava na casa de Lourdes. "Ela me ajudou de todas as formas que você pode imaginar. Fez o enxoval do meu filho". No entanto, reconhecendo a situação difícil em que se encontrava por aceitar uma adolescente naquelas condições, Lourdes propôs a Érica que, como ela ainda não era "de maior totalmente", compraria sua passagem, faria o enxoval para o bebê e Érica voltaria para sua casa. Depois, se ainda quisesse, poderia voltar para a casa de Lourdes. "Vou ter o maior prazer em trazer você de volta". Em princípio, Érica recusou a proposta.

Foi a primeira pessoa para quem trabalhou depois de ter saído da casa de sua mãe. Lourdes também tinha um filho com a mesma idade. Érica não dava conta de tomar conta de duas crianças.

\footnotetext{
${ }^{33} \mathrm{O}$ entorno são cidades do estado de Goiás, que, sob a orla de influência do Distrito Federal, experimentam o fluxo diário de moradores que vão trabalhar no Distrito Federal, procurar auxílio na sua rede de saúde, além de outros serviços (ver RIDE, anexo B).
} 
Até quando o Bruno [seu filho] começou a amamentar eu dava conta de cuidar, porque amamentava, dava a comidinha dele, colocava ele no berço. Mas depois que ele começou a andar - os dois bebês começaram a andar - aí já ficou mais complicado. [Então,] conversei com a Lourdes.

Lourdes aconselhou Érica a colocar seu filho na creche, mas Érica preferiu levá-lo para sua mãe. Sabia que com ela o filho seria mais bem cuidado.

Aí ela comprou as passagens, ela com o esposo bancaram as despesas. Eu fui lá, deixei ele, voltei e fiquei com ela. O Bruno ficou comigo um ano e pouquinho aí eu viajei para minha mãe. Tava começando a falar. Não dava para mim trabalhar e dar atenção para ele. Então, eu levei, deixei com minha mãe. Hoje é o braço direito dela. Ele não me chama de mãe, me chama de tia. A minha mãe é a "mãe" dele. Voltei para cá, voltei a trabalhar na mesma casa. A gente ficou ainda quatro anos. Então, chutando, tudo deu uns cinco anos.

Para Érica, o primeiro emprego no entorno de Brasília e a relação construída com a patroa foram profunda e positivamente marcantes:

foi o primeiro lugar que eu morei [quando saí de casa]: no Valparaíso II. Então, Lourdes para mim foi um recomeço da minha vida. Ela passou muita coisa boa para mim eu aprendi muito com ela. Eu tinha uma visão completamente diferente de patrões. Eu achava que patrão olhava para você e a única coisa que ele via [era] que.... Na realidade é isso, mas que existem pessoas muito boas. Depois disso eu saí. Foi a época que ela saiu do Banco do Brasil, para tomar conta do filho também. Saí porque ela desempregou, então, ficou só o marido dela trabalhando.

Érica residia na casa da patroa. Quando ficou desempregada entrou em contato com uma amiga que era da mesma cidade que Érica e foi morar com ela, no Gama ${ }^{34}$. Saiu da casa de Lourdes. Passou um tempo desempregada. Fez diárias por algum tempo. Depois disso, conheceu Dolores através de uma amiga passou a trabalhar para ela.

Com a Dolores, tomava conta das menininhas dela. Só que a gente se afeiçoa muito e o dia de amanhã você não pode contar. Você não sabe. Hoje você tá aqui, amanhã você tá acola e a gente quando vai cuidar de criança, principalmente o filho dos outros, você acaba sofrendo muito. Principalmente quando você tem que sair, você tem que se ausentar, e você tem que fazer uma escolha, e você acaba sofrendo. Sofre você e sofre a criança. Mas um dos trabalhos melhores que eu tive foi ter cuidado daquelas duas crianças (...). Quando eu saí, na época, da casa da Dolores parecia que tava saindo um pedaço de mim porque eu amava a Louise demais, demais, demais. Quando eu saí da casa da mãe dela, a menina sofreu tanto e eu também. Ela pediu para eu retornar. Eu ainda tentei mais uma vez, mas aí eu falei 'não, não dou conta'. Então, tanto sofreu a menina, como eu sofri muito. Porque a gente se afeiçoa. Às vezes o chefe pode não se afeiçoar a você, mas você acaba criando um vínculo. Você passa três, quatro anos, não é dizer que a pessoa não se afeiçoa. Claro que sim! Você tá todos os dias com aquela pessoa ali, todos os dias

\footnotetext{
${ }^{34}$ Região administrativa do Distrito Federal (ver Regiões Administrativas, anexo B).
} 
você tá vendo ele, ou, então, uma vez por semana, mas você tá vendo. Você tá lidando diretamente com ele.

Érica trabalhava e morava na casa de Dolores. Mas "não deu certo" em decorrência do marido de Dolores ter envolvimento com drogas e às vezes ficar violento. Ficou em torno de cinco, seis anos nesse emprego.

Ao falar da relação que constituiu no trabalho, Érica permite perceber várias dimensões a regular o convívio no ambiente doméstico. O medo do patrão, o amor da criança e mesmo dividem espaço com o sentimento de desvalorização. Nesse trabalho "o valor praticamente não existe. Se tiver uma ou duas que acaba te valorizando, ótimo. Mas muitas você trabalha a vida inteira e ela acaba não te enxergando. E a afeição. Você se afeiçoa muito a essas pessoas. Eu me afeiçoei a todos eles”, diz.

No caso de Érica, o sentimento de ser quase da família traz aspectos diferentes aqueles trazidos por Antônia, demonstrando também maior heterogeneidade das relações construídas no ambiente doméstico. Como Antônia, Érica aponta a disposição das pessoas para quem trabalhou em ajudá-la ao seu pedido. Diferente de Antônia, no entanto, a relação não é com o lugar ou com as pessoas como um todo; a relação é com cada um diferencialmente. Aparecem relações diferenciadas com cada membro da família.

\footnotetext{
Você acaba se tornando uma família, porque você participa do dia a dia daquela pessoa. Às vezes, por exemplo, eu tô trabalhando na sua casa, chega o momento que você chega, você quer conversar e a única pessoa que você tá vendo aí é a sua diarista, ou a sua empregada. Você vai acabar se abrindo, chegar e pedir um conselho, que às vezes Deus pode até usar aquela pessoa para te dar um conselho e o teu coração sair mais leve dali. Então, para mim, são vínculos que eu quero guardar para sempre. Só que tem um detalhe: diarista e mensalista traz muitas experiência boas para gente, mas muitas experiências ruins, desconfortáveis, porque eu passei por muitas situações complicadas e desagradáveis. Eu gostava da patroa, mas eu tinha que largar o trabalho. Às vezes a chefe ficava perguntando: "por que você quer sair?" Aí você fica sem escolha. Como é que você vai chegar e falar que o marido quer outras coisas além do trabalho? Graças a Deus nunca cedi a nenhuma situação dessas. Graças a Deus. É uma das coisas que eu tenho minha mente limpa. Eu preferia perder o emprego a trair a confiança de quem muitas vezes tinha estendido a mão para mim. Porque todas essas meninas que eu trabalhei, todas elas foram muito boas comigo. Eram pessoas que se eu chegasse e dissesse "olha, eu preciso disso", elas não mediam distância, elas não mediam esforços para fazer nada.
}

Na casa da Dolores havia uma diarista que dividia com Érica suas experiências de trabalho. Dizia: "Érica trabalhar de diarista a gente trabalha de mais porque o serviço que você tem para fazer numa semana você tem que fazer num dia”. Como Érica a ajudava, acabou aprendendo as tarefas da colega. Quando deixou de trabalhar para Dolores, por meio 
de uma amiga conseguiu um serviço de passar roupa no Park Way. ““'Érica, tem uma pessoa precisando de uma diarista. Você vai passar roupa na casa de uma mulher no Park Way”. Eu não sabia [nem] pegar ônibus [para chegar lá]. Fui chegar na casa da mulher já era quase 9h da manhã, mas consegui chegar”.

Foi muito importante [aquele trabalho], porque dela foi que eu consegui preencher a minha semana e garantir a alimentação do meu filho na casa dos meus pais, pagar meu aluguel, comprar as minhas coisas. E eu fui me acostumando [com o trabalho] porque eu comecei a gostar, porque cada dia eu tava num lugar diferente. Todo dia eu conhecia uma pessoa diferente. Então, para mim foi bom. As experiências que eu tive como diarista foram maravilhosas.

A sua rotina de trabalho, em princípio, era bem diversificada, incluía tudo. Érica conta que não só passava roupa. Tinha local em que passava, outros em que arrumava a casa e fazia tudo.

Tinha delas que, se o apartamento fosse pequeno e ela chegasse 'Érica, tem como você deixar o almoço pronto para mim?' Eu fazia sem problema nenhum. A gente tem que separar muitas coisas. Às vezes você vai trabalhar na casa de uma pessoa e por você não entender, às vezes a pessoa acaba aproveitando de você ou explorando o seu trabalho. Se é para você fazer "a" você tem que fazer o "b" e o "c" todinho. Eu sofri muito quando eu cheguei aqui. Eu tive que aprender andar com as próprias pernas. Eu fui criada de um jeito que, por ser filha única ${ }^{35}$, eu tinha tudo que eu queria. Tudo que minha mãe podia me dar e fazer por mim, ela fazia. E quando eu me vi grávida, só eu e Deus, eu tive que aprender a caminhar, tive que aprender a ter responsabilidade. Então, o trabalho para mim trouxe isso. Aprendi a conhecer as pessoas. Tinha pessoa que era muito boa comigo, tinha pessoa que era um pouco mais mesquinha, mas consegui fazer e realizar todos os sonhos que eu queria. Meu sonho era trabalhar, ter as minhas coisas, pagar as minhas contas, fazer as minhas coisas tudo direitinho e isso a diária me deu.

A realização conquistada não impede que Érica perceba os problemas que a função

trazia para sua vida.

O trabalho da diarista ele acaba adoecendo você, ele adoece você, ele tira muito das tuas forças. Quando eu vi que eu não tava dando conta falei 'vou fazer um curso que eu posso aprimorar'. Resolvi fazer um curso no SESC, porque eu poderia chegar a trabalhar num hotel. Achava bonito, achava chique. Aí eu comecei a entender o mundo da diarista. O trabalho de uma diarista é ou passa a roupa, ou cuida da casa, isso eu aprendi. Eu fiz o curso, a moça que ensinava disse 'você precisa ter coragem [de dizer para seus empregadores que trabalhar como diarista não significa fazer todo o trabalho da casa], se você não tiver coragem você não vai sair de onde você tá, você precisa ter coragem para conversar com todos eles. Vai ser natural alguém dizer para você 'não, então, para mim não dá mais'; mas se você trabalhar bem, você não precisa ter esse medo, porque quando você conhece o seu trabalho você não tem medo de perder um e ter que encarar o mercado de trabalho'. Eu perdi muita coisa, mas aquilo que perdi em seguida ganhei de

\footnotetext{
${ }^{35}$ Érica se refere a ser a única filha mulher. Tem outros irmãos.
} 
novo. E aí foi onde eu comecei a mudar minha vida e eu descansei um pouco mais. Antes, tinha dia que eu chegava em casa que eu ia tomar banho $2 \mathrm{~h}$ da manhã, que eu chegava tão cansada que só jogava a bolsa do lado deitava e dormia. Duas horas da manhã eu acordava e ia tomar um banho de tão cansada que eu ficava. Mas depois do curso, melhorei, tive atitude de conversar com todo mundo. Quem gostava e realmente respeitava o meu trabalho aceitou e a gente continuou, quem não gostava ficou sem, depois voltou atrás e eu já não tinha mais vaga. Detalhe: na minha vida como diarista, graças a Deus, nunca fiquei sem. Às vezes faltava espaço [na semana para as pessoas que tinham interesse em solicitar meu serviço]. Espaço esse que eu acabei preenchendo com os dias que eu devia ficar com minha família. Então, acabava sendo de segunda a segunda.

Tem muitos que interpretam a diária mal. Eu já trabalhei em casa que a pessoa sujava louca a semana inteira, ele não recolhia lixo, ele não fazia nada. Então, quando você chegava no apartamento tava um caos. Você chegava, da porta da frente já sentia aquele odor desagradável. Mas diária não é isso. Ela não envolve você lavar a louça de uma pessoa que passou a semana todinha sujando a louça da casa para sobrecarregar. Diária é limpeza. Você vai dar um grau na casa, debaixo de tudo, lavar o banheiro, é isso. Faxina de uma cozinha já é individual. Eu não sabia o que que era uma diária. Aí eu vi que estava sendo explorada, que algumas coisas já estavam passando do limite. Você organizar casa é uma etapa. Você passar roupa é outra etapa. Você chegou na cozinha já é outra etapa. Agora, se você formou um conjunto, se você acha que dá conta de passar roupa, dar uma faxina numa cozinha e ainda lavar louça e fazer comida para aquele chefe aí você já vai fazer um acordo em conjunto com ele. "Olha, eu vou fazer isso por tanto" [por tal valor]. E você vê se de fato você dá conta daquele trabalho. No meu caso, não. Quando eu fiz o curso que eu entendi isso, foi, então, que eu aprendi a separar. E para mim foi difícil eu chegar e conversar com o chefe ou a chefe. Mas eu tive coragem, cheguei e conversei: 'oh, você quer quantos dias meus? Eu posso trabalhar dois, três dias para você. Hoje eu venho limpar casa, a cada quinze dias ou trinta dias a gente dá uma faxina geral na cozinha porque não suja tanto e a gente vê como é que fica. E a roupa a cada quinze dias. Ponto. Se der certo para você, cada dia vai ser cobrado individualmente'. Então, é isso.

Quando Érica chegou a Brasília só tinha um filho, o Bruno. Depois de passar a trabalhar como diarista, conheceu seu esposo no Gama e foram morar juntos. Teve mais três filhos e duas filhas. Com o tempo conheceu uma família no Gama, através do seu marido e começou a trabalhar para a matriarca. A partir dela, passou a trabalhar para a família inteira.

Tem mais de doze anos que os conhece.

Chegou um tempo que eu comecei a ver que a diária tava tirando muito de mim. Nessa época eu trabalhava de segunda a segunda. Porque a diária tem muito disso, você acaba ficando sem escolha. Porque a diária, se você trabalha você tem, se você não trabalha, você não tem, porque você trabalha por dia. Então, daquele [rendimento] por dia você tem que fazer o mensal. Se você for uma pessoa organizada financeiramente você vai conseguir fazer o teu salário no final do mês. Se você não for, você vai só perder. Porque, vamos supor, hoje eu faço uma diária, hoje eu ganho R \$ 100,00, R \$ 150,00. Esse dinheiro já foi. Amanhã, se eu não tiver amanhã, e eu tiver gastado o do hoje, eu vou ficar na mão, entendeu? Então, você conta com o imprevisível. Trabalhar como diarista você tá praticamente trabalhando com o imprevisível. Hoje você tem, amanhã você pode não ter. Então, eu comecei a fazer o contrário, quando eu vi que a gente gastava de mais, eu procurava saber as pessoas que pagavam direitinho - porque a gente leva muito calote 
também, ainda tem esse detalhe, você confiar nas pessoas, e você terminar o trabalho e a pessoa 'não, vem amanhã pegar', 'não hoje eu não tenho', e, assim, vai -, comecei a selecionar as pessoas que eram corretas comigo, falava 'oh gente, vamos fazer o seguinte: vocês pagam só a minha passagem todas as vezes que eu vier e dia cinco de cada mês podem acertar comigo. Aí fazia um balanço do que eu trabalhava no mês e comecei a receber dia cinco. Aí começou a dar certo. Aí sim, eu comecei a ganhar dinheiro. Mas parecia que passava por entre os dedos, porque ao mesmo tempo que eu tinha, [eu] não tinha. Às vezes a gente conversava em grupo 'parece que dinheiro de empregada doméstica e diarista é um dinheiro amaldiçoado', porque ele não rende. A gente ganhava, vamos supor que eu tinha cinco residências para trabalhar; em cada uma dessas residências, no fim do mês eu fazia R \$ 600,00; aí você fazia um cálculo [de] quanto ia dar no final do mês e ficava feliz da vida. Quando você chegava com esses R\$3.000,00 na mão, fazia uma coisinha aqui, outra acolá, quando você pensava que não.... Tinha aluguel, água, luz, telefone - se tivesse tevê por assinatura -, tevê por assinatura, tinha que pagar pessoa - que na época eu já tinha mais filhos -, tinha que pagar pessoas para cuidar, tinha que pagar vã escolar e etc. Então, resumindo, quando você chegava no final....

Érica conta porque parou de trabalhar como diarista e da oportunidade que aproveitou para poder tomar essa decisão: "um dia cheguei em casa e fiquei pensando assim: a diária tá me tirando muito. Eu não tinha tempo para os meus filhos. Tempo para o meu marido, chegou um dia que meu marido olhou para mim e falou: 'você não é casada comigo, você é casada com seu trabalho"”.

Tinha domingo que o marido ficava muito decepcionado com ela, conta. Ele acordava de manhã, fazia café, arrumava as coisas e convidava Érica: "Vamos tomar café, amor?" Quando ele entrava no quarto e a via arrumada, sentia uma decepção muito grande, conta: "Você não vai ficar com a gente hoje?" "Não. Preciso ir trabalhar".

Então, diz Érica, ao mesmo tempo em que ganhava muito dinheiro fazendo diárias, também perdeu muito em outros aspectos.

Essa é uma parte da minha vida que eu não gosto nem de lembrar. Porque foi uma parte que me tirou muito tanto do meu casamento, quanto da minha família. Eu procurava trabalhar muito para dar o melhor para os meus filhos, mas o melhor não consistia no dinheiro. O melhor tava em estar com eles ali, dando amor, carinho, dando atenção para o meu esposo. Tanto é que hoje eu posso falar, eu perdi uma grande coisa trabalhando como diarista, como muitas dessas mulheres perdem. Eu perdi.... Os meus filhos são muito agarrados.... Eles me amam muito, eu sei que os meus filhos me amam, mas os meus filhos são mais agarrados ao pai do que a mim. Então, se fosse para voltar no tempo e...., depois que meu filho começou a sair e a se envolver com amizades.... Hoje eu me arrependo muito porque acho que muita coisa poderia ter sido diferente. Mas, às vezes, quando a gente tá trabalhando igual a gente trabalhava, eu queria saber que meus filhos estavam bem, queria saber que meus filhos estavam bem vestidos, estavam bem calçados, mas eu esqueci do mais importante: que a atenção, o amor e o carinho não tem preço. Não existe roupa cara que vai pagar, não existe perfume caro, não existe nada nesse mundo. A gente falta muito com a família porque a gente fica sem opção, porque ou você trabalha ou você dá atenção para tua família. Tem pessoas que conseguem conciliar, outras já não conseguem. No meu caso eu não consegui. 
Eu consegui ser uma mãe, sabe, dar tudo que eles precisavam. O que eles precisavam financeiramente falando, o dinheiro que eu ganhei em diária esses anos todos supriu, mas o mais importante eu não pude suprir porque eu não tinha tempo. Quando eu chegava em casa eles já estavam dormindo. Quando eu saia eles ainda estavam dormindo. A gente tinha o final de semana, quando tinha. Quando eu vi que tava perdendo casamento, perdendo filho, tudo, aí foi a hora que eu tomei uma atitude e resolvi mudar de situação.

Érica estava muito tempo tentando viajar e, certo dia, voltava no ônibus perguntando, em pensamento, a Deus: "Senhor quando eu vou viajar para casa da minha mãe, eu tenho tanta vontade ver minha mãe de novo". Então, quando estava chegando em sua casa seu marido ligou: "Você tá chegando?" "Tô chegando". "Tenho uma surpresa para você".

E naquele dia, disse Érica, o Senhor lhe deu uma resposta quando chegou em casa e um colega que a esperava falou: "Érica, você tem vontade de trabalhar fichada ${ }^{36}$ ?" "Eu tenho, mas acho que não dou conta, não. Não sei trabalhar..." "Érica, você vai trabalhar de serviços gerais, a mesma coisa que você faz em casa de família você vai fazer lá”.

Érica “achava que era um serviço difícil. Não tinha noção do que era serviços gerais”. Pensava que tivesse que lidar com outras coisas. Foi na época que entrou a $\mathrm{AST}^{37}$. O Seu Osmar, que a chamou para trabalhar como sua subordinada, tinha direito a indicar cinco pessoas e uma dessas foi ela. "Quando eu recebi a documentação todinha, que eu já estava fichada, que eu tinha que ir [para o novo emprego], aí e peguei e liguei para todo mundo. Já fui avisando e só deixei uma única pessoa que é essa que eu trabalho com ela até hoje".

Érica ganha como terceirizada $\mathrm{R} \$ 978,00$. Rendimento bem inferior ao que tinha antes. Começou uma nova etapa da sua vida onde teve que se adaptar, diz. Antes eu tinha dinheiro todos os dias. Agora, como terceirizada, passou a ter dinheiro uma vez por mês e ainda era pouco.

\begin{abstract}
Demorei bastante tempo, meu chefe me ajudou muito. Eu chorava. Dizia 'eu vou sair'. Ele dizia 'você não pode fazer isso, quantas pessoas não tão pedindo a Deus por um emprego desse, Érica, e você quer sair? Você vai dar conta, vai acostumar. Quando eu entrei aqui também foi difícil. Eu era lavador de carro e tirava muito mais, o dobro do que eu tiro hoje. Você vai se adaptar'. Deus foi trabalhando; Deus trabalhou na vida de muita gente para me ajudar, para me aconselhar, para estar do meu lado. A parte que mais me faz falta da época da diária....
\end{abstract}

\footnotetext{
36 "Fichada" é um termo que foi usado também por outras entrevistadas. Ser fichada é ter a Carteira de Trabalho e Previdência Social (CTPS) assinada.

${ }^{37}$ A AST - Assessoria de Serviços Terceirizados - era a empresa contratada pela UnB para executar serviço de limpeza e conservação nos seus campi.
} 
Érica não se permite concluir a frase. Diz não poder nem falar em sentir falta das diárias porque quando pensa na diária se lembra de ser filho. "Ele olhava para mim e falava assim: 'mãe, a senhora trabalha demais'. Ele não queria nada mais de mim, ele não queria roupa cara, não queria”.

Como terceirizada, Érica passou a trabalhar de segunda a sexta. Sai de casa às 5:20h da manhã e retorna às $6: 30 \mathrm{~h}$ da tarde. Sábado, para completar a renda, ainda trabalha como diarista para uma das filhas da matriarca do Gama nos finais de semana. Seu domingo é livre.

Meu domingo eu tô com eles. E sempre que eu posso eu chego para moça que eu trabalho, 'olha, sábado eu não vou poder vir. Eu não vou poder vir, eu vou passear, vou sair com meus filhos'. Então, não é aquela coisa mais que eu boto acima dos meus filhos, acima da minha família, hoje a minha família vem em primeiro lugar.

No domingo passa a maior parte do tempo com os filhos, "pega" um cinema, vai na casa de alguma irmã da igreja. "Se tiver alguma coisa na igreja participo". O domingo é dedicado à família.

\begin{abstract}
Hoje eu me considero uma mulher vitoriosa. Tenho uma família maravilhosa. Deus acabou de colher o meu filho. Através da religião que eu sigo o Senhor tem me dado conforto que eu preciso porque você perder um filho não existe explicação para chegar e falar "Paulo, é isso que eu sinto". Não tem, não tem explicação. Deus tem me confortado. Deus tem feito eu observar que tem muita coisa boa na minha vida".
\end{abstract}

Embora a mudança para a condição de terceirizada tenha ocorrido a mais de seis anos e a perda do filho tenha ocorrido no final de 2015, Érica reputa a morte do filho assassinado num acerto de contas envolvendo drogas à sua ausência no período de formação do filho, quando ele começou a andar em companhia de pessoas decisivas para esse desfecho.

Como diarista Érica não pagava contribuição, embora soubesse que podia.

Mas é complicado de pagar contribuição porque você acaba fazendo tanto compromisso e o último compromisso que você quer ter é você pagar INSS. Eu só consegui pagar INSS como terceirizada. E se você for fazer uma pesquisa são poucas delas que contribuem. Quando você não paga o INSS, quando você não tem nenhum planejamento a sua expectativa de vida é só trabalho, trabalho, trabalho, trabalho. Agora, quando você, hoje eu vejo a diferença, hoje eu ganho mais pouco, mas eu vejo uma qualidade de vida melhor. Hoje, se eu adoecer eu não vou ter medo de chegar num médico e falar "olha, eu não tô me sentindo bem, não tô dando conta", de medo dele chegar e me dar um atestado. Eu não vou ter aquela preocupação de chegar e falar "olha, eu tô de atestado, minha família vai passar necessidade". Não, eu tenho uma garantia porque eu estou contribuindo exatamente para que eu venha a ter essa segurança. Então, para mim hoje existe uma diferença muito grande, foi um salto muito grande que foi dado, né? Apesar de 
que você ganha mais pouco, você tem uma segurança. Antes eu ganhava bem, mas eu não tinha segurança. A gente, se adoecesse, no caso uma pessoa que não paga INSS, se ela não for segura, ela vai passar apuro mais à frente se for uma pessoa estourada de gastar tudo que tem. [Se for do tipo] passou na mão ela gastou, ela vai passar apuro, mas isso é certeza. Então, entre o passado e o presente, eu prefiro o presente. Foi uma mudança radical, mas foi uma mudança para melhor.

Nesse sentido, enfatizando a segurança de ser fichada, Érica fala sobre as vantagens do novo trabalho:

\begin{abstract}
A carteira fichada traz uma segurança, se você quer comprar um móvel, quer comprar alguma coisa, você sabe que, se você for um bom funcionário, você sabe que não vai ser mandado embora por besteira. Então, tendo responsabilidade você tem emprego para o resto da vida. E, na época em que eu trabalhava como diarista, não. Ao mesmo tempo que eu estava trabalhando, eu podia não estar, podia estar mudando de local de trabalho. Diarista é o seguinte, às vezes você faz um contrato com uma pessoa que leva tempo. Tem deles que passa por crise financeira. Se você tiver paciência, você consegue atravessar essa crise com eles. Se você não tem, no caso de uma pessoa que tem família grande, ele não tem condições de atravessar uma crise junto com o chefe porque ele já está trabalhando para poder dar o que comer para sua família e, daí, até esperar aquela pessoa se reerguer novamente para poder ajustar contas com ele, ele não vai conseguir. Para mim, a fichação da minha carteira foi um sonho, foi uma coisa realizada, então, hoje eu tenho segurança sim. Se eu disser 'oh, eu vou comprar esse celular à vista', eu vou juntar do meu salário todos os meses e vou conseguir. Eu tenho como juntar ele. Mas antes já não era assim. Porque a diária, hoje você tem, amanhã você não tem.
\end{abstract}

Érica diz que sua aposentadoria vai demorar muito tempo. Só tem cinco anos de carteira fichada. Se contar também com a época em que trabalhou como empregada doméstica, diz, deve estar próxima. "Preciso saber se por tempo de trabalho, se tá perto ou se tá longe, mas eu sonho com aposentadoria. Sonho em cuidar da minha casa, em cuidar de mim. Meu sonho é melhorar minha situação financeira e na minha velhice viajar". Como os filhos já vão estar casados, imagina, quer viver a velhice com família. Quer viver aquilo que não pode viver, diz. "Quero ser muito feliz junto com meu esposo, filhos, netos futuramente. A aposentadoria para mim representa felicidade, convívio familiar, aquela coisa de final de semana completo. Para mim é isso".

Sobre a única família que Érica manteve do tempo em que trabalhava como diarista, diz: "essa família que eu trabalho a mais de doze anos eu almoço com eles na mesa. Eles falam 'Érica, você não é nossa diarista, você faz parte da nossa família'. São pessoas que chegam para mim, sentam comigo, desabafam coisas intimas da vida delas. Eu me sinto muito bem".

A experiência mais positiva que teve na sua vida de trabalho, diz, foi nesse de doze anos. Aprendeu muita coisa sobre direitos e a correr atrás do que queria, a dar qualidade de 
vida para os filhos, a dar valor ao que ela tinha. A "chefe" 38 que tem hoje a incentiva muito: "Érica você é muito inteligente. Eu queria muito que você terminasse seus estudos e prestasse um concurso, porque você pode, você tem capacidade para isso”. Mesmo que Érica deixe de trabalhar para ela, quer continuar mantendo essa amizade porque ela esteve ao seu lado nas horas mais difíceis. "No momento que eu queria desistir ela tava ali comigo, me levantando, me dando força. É umas das experiências que marcou a minha vida e vai ficar registrada".

\subsection{Cleide}

Esposa de Simão, conhecido zelador de um prédio na quadra em que moro, sempre com boas histórias para contar, Cleide, 47 anos, com quem falava esporadicamente, aceitou de pronto o convite que lhe fiz diretamente, já que Simão insistia para que eu já fosse conversar com ela em vez de esperar sua intervenção para antecipar o convite que eu lhe faria para participar entrevista. Não havia qualquer combinação de onde seria a entrevista. No dia marcado, fui até a sua casa, Cleide me atendeu já saindo de casa e fechando a porta atrás de si: "Então, vamos?". E a entrevista transcorreu na república em que moro, felizmente sem nenhuma interrupção. Cleide morava em Santa Quitéria, Ceará, há quatro quilómetros de Fortaleza. O pai, agricultor, plantava milho, feijão entre outras coisas em terras de outros proprietários. Em troca lhes pagava com a terça parte da produção. A mãe só ajudava cuidando da casa e das seis filhas e quatro filhos. Ao falar sobre a sua cor, diz "parda", e acrescenta "era para ser negro, mas as pessoas dizem que é parda".

O marido mudou-se antes para a capital, arrumou emprego de zelador e, depois de um ano e pouco, Cleide mudou-se com o filho e a filha para reunificar a família. Simão trabalha até hoje nesse emprego. Isso faz doze anos. Cleide, logo que chegou já começou a trabalhar em apartamentos próximos ou até mesmo no prédio onde mora, embora não tivesse vindo com trabalho arrumado.

Em Santa Quitéria trabalhava com vendas de confecção, sua mesmo, tinha banca na feira.

\footnotetext{
${ }^{38}$ Termo em voga na terceirização que Érica usou inclusive para falar dos empregadores que teve como trabalhadora doméstica.
} 


\begin{abstract}
A vida lá eu achava melhor. Era meu negócio. O que eu fizesse era menos que eu ganhava aqui, mas morava num lugar melhor. Tinha alguém que ajudava, não gastava quase com nada e eu podia pagar uma pessoa que me ajudava porque os filhos eram pequenos. Lá também o pagamento de uma pessoa é bem pouquinho. Você dava o quê, [o equivalente a] $\mathrm{R} \$ 50,00$ por mês? Tinha alguém que me ajudava, eu achava bom nesse ponto. Só que aqui o pagamento é bem maior, mas é diferente você trabalhar para os outros e trabalhar para si mesmo principalmente pela liberdade. Se você não pode hoje, você não vai. Já se trabalha para os outros, precisa ficar dando satisfação. Muita vez o patrão não entende, precisa ficar levando comprovante, essas coisas.
\end{abstract}

Em toda a vida de trabalho o que gostou mais de fazer foi trabalhar para si mesmo em vendas. O que gostou menos de fazer é o serviço atual. Gostaria de ter outro trabalho. "Eu gosto muito de trabalhar com as pessoas, conversar, receber. Já fiz cursos para atendente, acho que eu dava conta de trabalhar em colégio, recepção... fiz até curso para isso, só que não procurei”.

Quando chegou a Brasília trabalhava como mensalista, mas sem registro. Não sabia exatamente a utilidade de ter carteira assinada. Só no terceiro emprego em casa de família foi que começou a trabalhar com registro. Nesse lugar lhe falavam: "você não pode, você tem que trabalhar registrada. Depois vai precisar para você... Se você tiver algum problema, você vai precisar disso". Agora que entendeu que é necessário, Cleide não trabalha mais sem ser registrada. Hoje, para Cleide, trabalhar registrada é importante para a aposentadoria, além do que, se acontecer algum acidente grave, pode ficar "encostada"39.

A partir de então, só trabalhou com registro, com apenas uma exceção.

\begin{abstract}
Nesse emprego, comecei a trabalhar sem registro. Foi um ano sem registro, aí eu falei que não podia trabalhar sem registro. Ela diz que não, que não registrava. Disse que não precisava. Eu disse: 'não, vou ficar só esse ano. Eu nem vou cobrar o que você tá me devendo porque eu aceitei trabalhar sem registro, mas agora, se você quiser [que eu continue], só se for registrada'. Aí eu saí porque ela não queria registrar. Isso foi em 2013.
\end{abstract}

Na casa em que trabalha por mês, além de cuidar da casa, Cleide toma conta de uma criança que a considera sua babá, embora nem Cleide, nem os pais da criança assim a considerem. "Não sou babá, mas sou uma Bombril", diz, se referindo ao fato de que, sendo responsável por cuidar da casa também se responsabiliza pela criança. Para Cleide, a criança sente falta só da sua comida, já que a mãe da criança não sabe cozinhar nada.

Como a família é vegetariana, Cleide não come no emprego. Então, trabalha das $8 \mathrm{~h}$ às $12 \mathrm{~h}$, desce para almoçar e retoma às $14 \mathrm{~h}$. Fica até acabar o serviço, geralmente às $3 \mathrm{~h}$ ou

\footnotetext{
${ }^{39}$ Ficar de atestado médico.
} 
4h. Mas, quando os pais da criança não estão em casa, pode ficar até às $8 \mathrm{~h}$ da noite para tomar conta da menina. Nunca teve oportunidade de sentar-se à mesa com os empregadores. "Mas eu acho que se precisasse não teria problema não. Eles são muito simples".

As diárias são uma renda a mais. Como trabalha de segunda a sexta, as possibilidades que aparecem são nos sábados. "Não faz direto, mas é melhor que mensal". Cleide é conhecida no prédio e nas imediações por ser mulher do zelador, um homem bem relacionado. Além disso, por trabalhar na vizinhança, as pessoas para quem Cleide presta ou prestou serviço são conhecidas, e, portanto, suas referências são acessíveis, razão pela qual consegue trabalhos esporádicos de ficar à noite tomando conta crianças quando os pais delas vão a algum concerto ou sair para jantar. Para ela, além da renda, a diária é melhor também

\begin{abstract}
porque cada dia está numa casa diferente é melhor. Passar um ano, dois três, todo dia a mesma coisa... [é ruim]. Eu gosto de novidade, [de] coisas diferentes. Por isso também que é bom diária, cada dia você está numa coisa diferente. Cada dia está num ambiente diferente e também você ganha mais. Na diária você trabalha mais porque tem que limpar tudo. A mensalista cada dia faz um pouco. O trabalho é mais leve e ganha menos. O outro é mais pesado. Eu preferiria ficar só com a diária se tivesse todos os dias, né? Para você trabalhar como diarista você tem que ter a semana certa. Não adianta você trabalhar com a diária numa semana e na outra semana não trabalhar mais. Tem que ter a semana certa. Eu tenho medo de ficar fazendo diária e ter mês [de ficar sem]. Tenho uma amiga que faz isso, [tem semana que] fica com uma diária [só], aí atrasa toda sua vida. Porque [no vínculo mensal] você trabalha sabendo tudo que você tem que pagar no final do mês, né? E se você trabalha em diária sem ser fixo e fica só com uma, aí é bem complicado.
\end{abstract}

Sobre o trabalho de mensalista que executa,

Na verdade, eu não gosto desse trabalho doméstico. Eu trabalho, acho que já me acomodei, sabe. Eu tenho chance de trabalhar com o que eu quero. Eu me acomodei por conta do local, que é no mesmo local que moro, desço na hora que der certo. Tô perto dos filhos a toda hora. Eu acho que foi isso que fez eu continuar nesse trabalho. Porque quando eu comecei eles eram pequenos e aí precisava muito. Ficavam só com o pai que ficava aqui em baixo. Eu achava que trabalhando aqui, qualquer coisinha que me avisassem eu descia, né, e já estava cuidando. Hoje já tenho uma de maior e o outro já tá com quinze e eu continuo no mesmo trabalho para estar perto.

A filha faz nutrição na Unieuro. Queria medicina. Mais aí pela dificuldade opinou por fazer um curso que fosse mais ou menos o que ela queria. "Pra mim não importa qual o curso, o que importa é que eles tenham uma formação", conta, ao dizer que o sonho é ver os filhos formados.

Cleide terminou o ensino médio. Estudou enquanto trabalhava uns sete anos. Começou a estudar tarde, acredita. Morava na cidade do interior. 
Então, a gente estudou até a quarta série em escola de fazenda. Nessa época o governo não tinha nada, plano nenhum. Hoje eu vou lá onde morei: não tem mais pessoas como eu fui criada que estudavam só até a quarta série porque não tinham oportunidade de estudar na cidade porque não tinha transporte. Tinha que pagar do bolso, meu pai não tinha condições de pagar aí a gente ficou sem estudar, estudava só o que tinha na fazenda. Hoje não, hoje o carro vai pegar na porta. Todo esse pessoal que mora em chácara terminou seus estudos, outros estão fazendo faculdade porque o governo paga tudo. A gente não teve essa oportunidade.

Quando Cleide chegou a Brasília, ficou uns dois anos ou três sem estudar. Nem acreditava mais em voltar à sala de aula. Diz: "achava que aquilo tava bom, sabia fazer nome, sabia ler e escrever". Também tinha vergonha por se achar velha de mais para voltar a integrar uma turma de quinta série. Conheceu uma senhora que estudava no Gama e era mais velha do que Cleide que a convidou a voltar para escola. Cleide aceitou, foi lá e se matriculou.

Cleide gostaria de tentar trabalhar em outro serviço. Tendo tido oportunidades de trabalhar noutro serviço, não sabe dizer muito bem por qual motivo não deixou os serviços domésticos, mas acrescenta que, em parte, se deve ao fato de pensar muito na pessoa para quem tá trabalhando.

$\mathrm{Na}$ época que surgiu o serviço para mim, e era nas férias, veio de uma rede de cosméticos para ser vendedora. Só que eu pensei no patrão: 'tem suas crianças, quando eles voltarem como vão arrumar outra pessoa assim, de imediato'. Mas eu me arrependo de não ter pego porque, por melhor que seja o patrão, nunca eles vão pensar desse jeito, deixar de fazer alguma coisa por uma empregada. Jamais. Eu deixei. Agora, tenho vontade, mas para mim ir atrás de outro serviço eu preciso de um mês de - como é que a gente fala? - aviso prévio.

Cleide atenta para o fato de que o aviso prévio a impediria de sair do trabalho prontamente caso conseguisse outro trabalho, o que seria um problema já que a nova oportunidade não esperaria até que Cleide pagasse o aviso. "Então eu penso nisso, algum dia que eu falar, 'não, eu vou atrás de outro serviço', que seja numas férias que aí não tem como. Ou, então, avisar um mês antes que eu vou ficar um mês parada para procurar esse trabalho". Entre casa de família e lugares como hospitais, escolas, Cleide pensa ser melhor ficar em casa de família por trabalhar para um número reduzido de pessoas. Se for para deixar o tipo de trabalho que tem, pensa em arrumar serviço em atividades mais distantes da que tem hoje, como em loja, comércio ou, farmácia. 


\subsection{Cecília}

Cheguei a Cecília inicialmente através de um dos números telefônicos que Cleide havia me passado de amigas que poderiam contribuir com a pesquisa. Inicialmente, as entrevistadas tinham a possibilidade de optarem por não serem gravadas. Quando Cecília fez essa escolha, percebi que a entrevista não transcorreu a contento, já que demandava muito tempo escrevendo e isso interferia na relação face-a-face com a entrevistada. Em decorrência disso, se tornou uma entrevista mais impessoal, onde as respostas eram dadas de forma mais objetiva. Algumas vezes, tentando "esticar" a resposta, fazia algumas sugestões que muitas vezes acabavam sendo acatadas sem reserva, sem outros comentários adicionais que indicassem a profundidade que a resposta dada tinha na vida da entrevistada. Nesses casos onde ficou a impressão de que as respostas se tratavam da emulação de uma resposta "certa" derivada da leitura feita pela entrevistada sobre o entrevistador, as respostas não foram consideradas. Depois dessa entrevista, eliminei a possibilidade de não gravar nas entrevistas posteriores. A trajetória de vida de Cecília, no entanto, traz muitos elementos interessantes, por isso decidi considerar sua entrevista, colhida no espaço comum do prédio onde o marido trabalha como zelador.

Cecília, 35 anos, morava três quadras depois da minha. Nascida em Felizardo, Ceará, onde era estudante. Católica, filha de pais agricultores, tem duas irmãs e um irmão. As mulheres são donas de casa o irmão não trabalha. Cecília terminou o segundo grau. Quer fazer faculdade a distância de geografia ou pedagogia. Para isso já está planejando fazer cursinho.

Em 1998, mudou-se com o marido para Brasília. Arrumou emprego quando já morava na cidade. $\mathrm{O}$ primeiro foi como mensalista tomando conta de uma criança. Trabalhou cinco anos e tinha carteira assinada, recebendo pouco mais do que um salário mínimo.

Teve o primeiro filho em 2002, o Henrique, hoje com treze anos. Saiu do emprego para cuidar dele. Voltou a trabalhar alguns anos depois, esporadicamente, em princípio, para poder cuidar do filho. Cerca de sete anos depois do nascimento de Henrique, voltou a trabalhar a maior parte da semana.

Hoje preenche a agenda semanal. Trabalha há dez anos para sua cliente mais antiga e há dois anos para a mais nova. Ganha em torno de $\mathrm{R} \$ 2.000,00$ por mês. Trabalha só em apartamentos menores, não faz faxina em casa nem em apartamento grande. Toda vez que precisa pegar ônibus para ir trabalhar os empregadores pagam. 
Moradora da Asa Norte de Brasília, onde o marido também trabalha como zelador, faz faxina só no Plano Piloto. Na sua faxina arruma, lava banheiro, passa roupa e, às vezes, cozinha. Tudo isso em um período ${ }^{40}$. Trabalha em três lugares, alguns mais de uma vez por semana. Cobra por cada diária em torno de $\mathrm{R} \$ 100,00$. Quando tem mais de uma faxina marcada para o mesmo dia, sai de uma e vai direto para outra. Nesses dias, para economizar tempo faz sua refeição nos lugares em que trabalha, inclusive sentando-se a mesa com seus empregadores.

Cecília conta que, dentro em breve, vai ser fichada numa casa onde vai trabalhar quatro dias na semana. Embora já tenha alguns direitos trabalhistas assegurados por conta de pagar contribuição previdenciária autonomamente há três anos - e vá ganhar menos considera que terá mais vantagem ter décimo terceiro, férias, licença. “Às vezes a pessoa adoece, além de que quando a acontecer alguma coisa e não puder trabalhar pega atestado e recebe". Nos outros dias vai continuar na faxina. Mas não nos finais de semana. "Sábados e domingos é para descansar".

\section{5 ÂNGELA}

No Recanto das Emas, fui alertado por Laura, que me apresentaria a Ângela, quando já estávamos chegando na sua casa, sobre a forma incisiva como Ângela se expressava que por vezes provocava estranhamento. Definitivamente não me lembro em que termos me disse isso. Ângela foi muito receptiva e delicada, mas muito diretamente criticou meu atraso de poucos minutos. "Essa chuva me atrapalhou um pouco", justifiquei. A entrevista foi acompanhada pela amiga que nos apresentara, que não raras vezes completava as respostas, o que foi muito bem-vindo porque ao mesmo tempo que estimulava Ângela a dizer mais coisas, ela não é alguém influenciável impedindo que a “ajuda” pudesse atrapalhar a entrevista.

A entrevista com Ângela também foi curta não tanto em função do tempo da conversa, mas em função tanto da "objetividade" das respostas e quanto de como aproveitá-las no contexto da dissertação. O fato de a entrevista ter transcorrido num dia chuvoso, embora tenha obrigado Ângela a reorganizar os compromissos que tinha marcado no dia, isso teve uma influência diminuta no tempo da entrevista. Por resposta objetiva não se deve entender

\footnotetext{
40 Popularmente dito "meio período", talvez em referência a jornada de trabalho convencional de 8 horas, o período é uma das subdivisões do dia: manhã, tarde ou noite.
} 
de modo algum que fossem respostas sem espírito ou influenciadas pela leitura feita sobre o que o entrevistador espera que seja a resposta "certa". Não. Sem dúvida Ângela entre todas as entrevistadas foi a que demonstrou menos preocupação sobre o que quer que eu fosse pensar sobre as respostas que me dava. Chama atenção na entrevista com Ângela a exatidão cronológica dos fatos narrados. Em todos as outras entrevistas isso não foi tão exato quanto com Ângela.

Ângela, 62 anos, é natural de Giubués, Piauí, onde trabalhava na roça. Quando lhe pergunto sobre sua cor, responde: "Morena. Preto, não; negro, não". Evangélica da Igreja Mundial do Poder de Deus. Pertence a denominação a quinze anos. Tem seis irmãs e quatro irmãos. Separada do marido, mudou-se para Brasília em 1978, com 27 anos. Quando se mudou, duas de suas irmãs já moravam em Brasília. Ângela, que ainda não tinha trabalho arrumado, não demorou um mês até começar a trabalhar em casa de família na condição de residente.

Chegou em Brasília grávida. Quando a filha nasceu, levou e deixou-a com a mãe no Piauí. Dormia na residência em que trabalhava, mas nos fins de semana ia ficar com as irmãs. Na primeira residência em que trabalhou, foi durante dois anos e quatro meses; na segunda, durante quatorze anos. Conta que no mesmo dia em que deixou esse último trabalho de mensalista já tinha outro trabalho disponível.

Há 23 anos Ângela é diarista. Tem quatro clientes, trabalha de terça a sexta. Em duas casas trabalha a 23 anos. Nas outras, cinco e três anos. Ganha mais ou menos R $\$ 2.000,00$. Ângela não só faz faxina, "não mistura serviço". Conta que hoje não trabalha tanto como antes porque, diz "as carnes vai diminuindo a força".

A filha voltou a morar com a mãe há treze anos. Ajudou a mãe, que já tinha terreno, a levantar a casa, que era o primeiro sonho de Ângela. Muito firme e decidida, respondendo à uma pergunta feita, Ângela conta que o que pesou na sua transição de mensalista para diarista foi o fato de não ter direito nenhum onde trabalhava. Poder voltar a morar com a filha não teve influência na sua decisão, embora, conta, sonhava "toda vida" em fazê-lo. Hoje, o seu sonho é ver a filha casada e bem aprumada.

\subsection{ZÉLIA}

Havia conhecido Zélia há alguns anos, quando dividi uma quitinete com Hélio que solicitava seus serviços de diarista uma vez por mês. Embora parecesse que se lembrava 
pouco de mim, logo que começamos a conversar perguntou-me "e o Helio?" Quando lhe disse que não o via mais ela acrescentou: “ele é uma pessoa difícil, né?” Descoversei. Nesse momento, já tinha lhe falado sobre a entrevista e diante da sua afirmativa de que participaria da pesquisa, perguntei qual seria um bom dia. Zélia respondeu que estava livre, afinal já era o começo da noite, e que se eu pudesse acompanhá-la conversaríamos no bar no térreo do prédio onde fica a sua quitinete.

Natural de São Francisco, Minas Gerais, já tinha trabalhado em duas casas de família como mensalista antes de partir para Brasília. Na época não teve a carteira de trabalho assinada. Não sabe nada sobre o pai, a mãe trabalhava na roça. Tem três irmãos. O irmão trabalha em chácara. As duas irmãs são diaristas.

Ao perguntar a cor, Zélia responde: "normal”. Não tem filhos. Moradora da Asa Norte do Plano Piloto (ver anexo B), onde grande parte dos moradores é formada por estudantes universitários, Zélia mora sozinha numa quitinete de dois cômodos na Asa Norte. Mesmo em se tratando de um endereço numa rua comercial, em que os aluguéis são bem mais baratos que o de edifícios residenciais, é incomum trabalhadoras domésticas residirem na região. Negra ${ }^{41}$, talvez a discrepância racial e profissional em relação ao meio circundante tenha levado o casal de vizinhos com a fisionomia de estudantes universitários recém-formados que se aproximava a se sentirem à vontade em interromperem a conversa que mal começara para pedir emprestado a Zélia sua chave para entrarem no prédio em vez de sacarem a sua própria, que demostraram desistir de procurar depois de algumas apalpadas nos bolsos das calças e de mal terem acabado de abrir o zíper da bolsa carregada pela mulher.

Zélia mora em Brasília há quase trinta anos. Mudou-se a convite de uma amiga que estava na cidade e arrumou trabalho para Zélia. Assim, já tinha trabalho arrumado quando chegou na capital. Em Brasília, morava na residência da família em que trabalhava, onde permanecia até os finais de semana. Como o salário era ruim, trabalhou apenas um mês nessa casa.

Na segunda residência em que foi trabalhar, dessa vez fichada, ficou por dezoito anos. Também morava no serviço. Lá, "tinha um bebê que hoje tem onze anos de idade”. No momento da entrevista em que Zélia demonstrou mais energia, diz. "É como se fosse meu filho, até hoje. Inclusive fui ver ele lá no colégio. É minha vida esse menino. Cuido como se

\footnotetext{
${ }^{41}$ Heteroclassificação racial feita pelo entrevistador.
} 
fosse meu filho, hoje". Zélia saiu desse trabalho na mesma época em que a criança nasceu, mas manteve vivo os laços de amizade que tinham sido construídos.

Depois desses dezoito anos fui trabalhar.... Eles arrumaram serviço para mim na ANAC [Agência Nacional de Aviação Civil], fiquei cinco anos. Depois fui trabalhar na FUNAI [Fundação Nacional do Índio], fiquei dois anos. Depois eu saí por causa de empresa. Entrava um coordenador, entrava outro e outro e ia mandando as pessoas embora.

Era empresa terceirizada. Tem uma lembrança ruim de quando trabalhava na ANAC, quando a empresa findou seu contrato sem pagar sua rescisão para os funcionários. "Não pagou na época, mas depois pagou. Entrou na justiça”. Zélia conta que passou muito aperto na época.

Na época que fui copeira eu gostei. Fiz o meu curso, gostei muito de trabalhar na
FUNAI, mas chegou uma época que não dava mais e não continuei trabalhando
como copeira. É muita pressão, eu acho muita pressão. Você tem que fazer as
coisas e não errar. Para você mexer com café tem que saber mexer, tem que ser
muito limpa na copa, tem que ter muita responsabilidade, tem que chegar cedo,
tem que chegar no seu horário, isso aí eu sempre faço. Gostei muito. O negócio
que eu não gosto é porque troca sempre de coordenador e acaba mandando um
bocado de gente embora. Você não tem segurança.

Zélia se refere a rotatividade entre empresas terceirizadas que infelizmente não é algo incomum. A rotatividade entre empresas contratadas tem duas consequências: por um lado, quando findam o contrato de trabalho com a instituição contratante demitem os funcionários que faziam parte do quadro absorvido para a execução da tarefa contratada. Por outro lado, quando não há demissão e os funcionários são recontratados pela nova empresa licitada, muitas vezes a substituição de empresas acontece antes de serem obrigadas a concederem as férias aos empregados e empregadas, o que ocorre depois de um ano e onze meses de trabalho. Assim, rotatividade, então, significa para funcionários e funcionárias, por um lado, poucas garantias sobre a permanência na empresa, o que provoca uma ansiedade constante pelo recorrente risco de perderem o emprego. Por outro, quando permanecem no emprego, há poucas garantias sobre direitos adquiridos, o que pode resultar em anos a fio trabalhando sem férias, ainda que recebam por elas. Como muitos funcionários e funcionárias de empresas terceirizadas são de outros estados, isso ocasiona que fiquem anos sem ver pais, mães, irmãos e irmãs que moram longe. 
A fala acima mostra o critério de julgamento que Zélia estabelece para gostar do trabalho. Não se trata do tipo de atividade, mas do tipo de administração a que estava submetida.

Depois arrumei um trabalho na academia [de musculação] fichada. Trabalho na limpeza lá vai fazer cinco anos. Tô lá e [concomitantemente] trabalho como diarista na parte da manhã e na academia eu entro às $4 \mathrm{~h}$. Tem muitos anos que faço diária. Comecei depois do emprego de dezoito anos. Tenho minhas diárias fixa. Tem cinco pessoas que eu trabalho toda semana. Um dia em cada casa.

$\mathrm{Na}$ academia, trabalha de segunda a sexta. Aos sábados, Zélia e suas três colegas de trabalho fazem um revezamento onde cada uma trabalha num sábado. Na diária, já trabalhou de segunda a sexta e às vezes, como não tinha vaga na sua agenda durante a semana, trabalhava no domingo. Hoje, "tem dias que eu fico livre. Eu já tava ficando muito cansada e já tava ficando com estresse eu larguei a segunda, a terça e a quarta para resolver meus problemas e ter tempo para minha casa. Só que agora eu tô de folga só terça e quarta”. Zélia não quer preencher esses dias porque é muito cansativo. "Eu trabalho não é só com as diárias. Eu tenho meu serviço fixo também. Conheci a maior parte das pessoas que faço diária no meu trabalho, na academia”. A maior parte das diárias que Zélia faz é perto de sua casa, indo trabalhar a pé. Só há necessidade de pegar ônibus em três casas.

Em todas as diárias, Zélia faz limpeza:

às vezes eu passo também (...), às vezes eu cozinho também (...). Tem uma casa que eu faço isso sempre, toda quinta feira eu cozinho, deixo a comidinha pronta. Faço a comida, deixo pronta, uma comidinha básica para deixar para pessoa e almoço também. Faço a comida e a limpeza. Em duas casas, além da limpeza também tem que passar, uma [casa] que eu comecei agora e tem outra casa que eu vou na sexta-feira de quinze em quinze dias, para um casal. Toda vez que eu chego lá eu arrumo e passo.

Em geral trabalha mais ou menos um ano para os clientes que tem hoje nas diárias. Nunca pagou contribuição pelas diárias.

se eu for cobrar mesmo, não sai $\mathrm{R} \$ 2.000,00$. Tem casa que você não ganha $\mathrm{R} \$$ 100,00 . Por que é que eu não cobro? Porque é uma kit [quitenete] pequena; eu faço aquilo de 7 h até meio dia, não é o dia todo. Nesse caso eu cobro R\$90,00, R\$ 100,00 . Mas o preço é entre $\mathrm{R} \$ 100,00$ e $\mathrm{R} \$ 120,00$. Por mês deve dar uns $\mathrm{R} \$$ 1.000 e pouco. $\mathrm{R} \$ 1.000,00$, mais ou menos. Porque tem casa que é de quinze em quinze dias. Tem casa que é toda semana.

Ao diferenciar o trabalho de diarista e mensalista, Zélia diz que: 
como diarista você vai dar uma geral na casa. E, como mensalista, estando todos os dias ali, cada dia você faz uma coisa. Você estando frequentando todo dia aquela casa você não faz tudo de uma vez. Como diarista você tem que fazer e deixar tudo limpo para próxima vez que você for. A diarista tem que deixar tudo organizadinho, tudo limpo para na próxima vez você faz a mesma coisa. E você estando na casa da pessoa fixo você tem que dormir, tem que ficar; e diária, não. Você faz a diária e vai embora.

Já, ao julgar entre os diferentes tipos de trabalho em que faz limpeza, Zélia pondera sobre os atrativos de cada um: o "dinheirinho" que tem constantemente nas cansativas diárias, mas sem segurança de que o terá no futuro e o "dinheiro" que tem apenas uma vez por mês no trabalho mensal, mas que é garantido.

Entre a academia e as diárias prefiro as diárias. Eu gosto da academia, gosto de trabalhar na limpeza, mas as diárias você sempre tem um dinheirinho. Na hora que você termina você sempre tem que ter o dinheiro, tá entendendo? Terminou o teu serviço.... Eu gosto da academia e das diárias. Só que as diárias são muito cansativas. Todas as duas são boas. Na academia, lugar que eu trabalho de segunda a sexta, sou fichada e todo mês você tem aquele dinheiro [garantido], você é fichada, entendeu. E nas diárias não, nas diárias você não tem aquela segurança, você tá entendendo?

Na academia, ganha um salário mínimo, passagem e os tickets da escala de sábado.

Fico na academia porque lá tenho carteira assinada. O Fundo de Garantia é mais seguro porque, às vezes naquele momento você não tá trabalhando e não consegue um trabalho. Acho importante por isso. Acho importante por causa disso, [do] seguro-desemprego, [e do] Fundo de Garantia. Porque você tá desempregada, mas você tem segurança de que vai receber aquele dinheiro. Você tem que comer, você tem que vestir, como eu..., eu sustento minha família. Tenho que comer, tenho que me vestir, tenho que pagar meu aluguel. É seguro por causa disso. Ajuda a ficar mais tranquilo, mas é muito preocupante. Eu pago $\mathrm{R} \$ 800,00$ com despesa, condomínio, conta de luz vai uns R\$1.000,00 por mês (...). Como a gente que é diarista, a pessoa que é diarista ela não tem carteira assinada, não tem nada. Porque se você adoecer o que é que você vai fazer? Você não tem Fundo de Garantia, não tem segurança. O que é que você vai comer? Com que é que você vai pagar seu aluguel?

Já teve ajuda de muitos empregadores para comprar alguma coisa. No trabalho que Zélia teve por dezoito anos, até hoje a patroa a ajuda. Foi ela que mobiliou sua casa. Com ela Zélia ainda troca presentes em ocasiões especiais. Ao terminar a entrevista, como de costume, entre perguntas sobre o que a entrevistada achou da entrevista, suas opiniões, perguntei também se Zélia tinha alguma indicação a fazer de outras diaristas que pudessem participar da entrevista: "Não. Não tenho. Elas moram todas nas cidades satélites". 


\subsection{FLÁVIA}

Flávia me foi apresentada por Plínio, um amigo com quem sempre almoçava no restaurante da Universidade de Brasília. Ele era integrante da Empresa Júnior de Economia da universidade, que contrata os serviços de Flávia às terças-feiras. Conversamos no horário do lanche no colégio na Asa Norte onde cumpria uma segunda jornada de trabalho.

Flávia, tem 48 anos, nasceu em Raul Suarez, Minas Gerais. Embora se classifique como parda, dificilmente seria heteroclassificada como não-branca. O Pai, que era motorista pelo GDF (Governo do Distrito Federal), já trabalhou como lavrador. A mãe, diz, é dona de casa $^{42}$. Tem duas irmãs e cinco irmãos. Uma irmã trabalha na Unimed Seguros a outra mora em fazenda. Dois irmãos estão desempregados, um faleceu, um trabalha na CAESB (Companhia de Saneamento Ambiental do Distrito Federal) e outro militar. Mudou para Brasília, há 35 anos: "meu pai veio, então, a gente foi obrigada a vir, que era tudo criança".

O marido faz faculdade de direito, no Instituto Brasiliense de Direito Público - IDP -, “do Gilmar Mendes”. Já Flávia terminou o segundo grau, mas não fez faculdade por falta de oportunidade. Tem que trabalhar. "Ou um estuda ou outro, né? Pretendo voltar a estudar. Quero estudar artes. Trabalho o dia todo e parte da noite. Não tem horário vago para poder estudar. Por isso eu não tô estudando”. Flávia tem plano de voltar aos estudos. Fez pedido para a chefe mudar seu horário para fazer faculdade à noite. "Se [eu] passar em uma [faculdade] pública melhor, se não tem que ver um local mais em conta".

Flávia e a família moram em Sobradinho, em casa própria. Tem duas filhas com dezenove e doze anos. A mais velha faz Ciências Naturais na Universidade de Brasília. A de doze anos está no ensino médio. Quer fazer Veterinária. As duas filhas ajudam a cuidar da casa, fazem comida e cuidam dos dois gatos e dois cachorros que têm. $\mathrm{O}$ marido, que trabalhou durante 27 anos numa empresa de contabilidade e agora foi demitido, também ajuda: faz comida, limpa casa, só não lava roupa, mas passa roupa também.

"Meu primeiro emprego foi em casa de família. Tinha dezesseis anos". Trabalhou nesse emprego por oito meses. Saiu porque discutiu com a babá. Não era registrada nessa época.

\footnotetext{
${ }^{42}$ Em seguida veremos a entrevista de sua mãe, que não se considera uma dona de casa.
} 
Depois foi trabalhar como auxiliar de odontologia. Trabalhou quatro anos. Engravidou. Quando acabou a licença, pediu demissão porque o salário que teria de pagar para alguém cuidar de sua filha era maior que o que ganhava. "Fiquei muito tempo [em casa] até ela pegar uma idadezinha de poder deixar no colégio e poder trabalhar. Foi uns sete anos". Depois de alguns anos, voltou a trabalhar.

Quando voltou, trabalhou na Ordem dos Advogados do Brasil - OAB - como copeira, por dois anos. Quanto mudou a gestão da empresa terceirizada, demitiram as pessoas que faziam parte do quadro antigo e, entre eles, Flávia. "Depois da OAB, aí eu fiquei trabalhando de diarista, só diarista". Atividade que hoje concilia com a de faxineira registrada em um colégio particular de Brasília.

Flávia gosta do seu trabalho como diarista, tanto que nunca faltou ao trabalho.

\begin{abstract}
se eu não for algum dia por motivo de doença tem que arrumar uma pessoa para ir no meu lugar. Eles já falam: "se você não puder vir, me indica alguém", porque não pode ficar só. Porque as mães têm contato comigo, então, eu tô aí cuidando dos filhos delas e quando eu não posso ir eu tenho que avisar para ir outra pessoa cuidar deles, mas nunca precisou. Eu não sou muito de faltar ao serviço. Mesmo sendo fichada, eu não gosto de atestado, eu não gosto de faltar. Quando eu faltei na época em que trabalhava no consultório foi a necessidade. Por causa da minha mãe. Porque as pessoas pensam: 'por que trabalha de diarista, se não for vai perder o dinheiro', né? Eu já não penso assim: só o dinheiro. Eu penso na pessoa também. Porque a pessoa tá me pagando, tá contando comigo e eu não vou trabalhar, eu acho injusto. É igual aqui, no colégio. Só se for um caso de extrema necessidade eu não vir e deixar minhas colegas na mão. Porque se eu não vir, vai estar prejudicando alguém que vai tá trabalhando mais que o normal.
\end{abstract}

Flávia entra no trabalho às $7 \mathrm{~h}$ da manhã e só acaba tudo às $9 \mathrm{~h}$ da noite. De manhã faz diárias até $12 \mathrm{~h}$. Trabalha cinco vezes por semana, de segunda a sexta. Em todos os lugares presta serviço uma vez por semana. Flávia costuma trabalhar para pessoas mais jovens, em geral estudantes da Universidade de Brasília - UnB. Em duas das casas em que presta serviço trabalha desde o tempo em que iniciou como diarista, está há mais de 14 anos com eles. Além destas, tem um cliente de doze anos; outro para quem trabalha há dois anos e também trabalha como diarista na Econsult - empresa júnior do curso de Economia da UnB. À tarde trabalha numa escola como faxineira das $12 \mathrm{~h}$ às $9 \mathrm{~h}$ da noite, com uma hora de almoço às $14 \mathrm{~h}$. No sábado trabalha na escola até $11 \mathrm{~h}$ da manhã.

Nos lugares onde Flávia trabalha fica tudo para ela fazer. Até as louças sujas é ela quem lava. 
semana para organizar. Então, eles são totalmente dependentes de uma pessoa que vá lá uma vez por semana, até para lavar um copo, que vai acumulando na pia. Aí você chega lá, tá tudo sujo. Às vezes eu lavo, passo, faço comida, faço comida para semana, congela e deixa. Porque é estudante, né, não tem tempo. Tem que fazer a comida além da limpeza, às vezes a roupa tem que lavar na mão. Isso em meio período. Tem que ser rápido. Tem que ter uma organização boa.

Flávia sai de Sobradinho e todos os seus trabalhos ficam no Plano Piloto (ver anexo B), vai de um emprego para o outro e tem que trazer a marmita. Em nenhum lugar onde trabalha come ou toma café.

A gente só faz a comida. A alimentação é deles. Eles já avisam quando entram que a alimentação sua você tem que trazer, porque eles moram aqui e dependem dos pais e os pais mantem eles aqui e tem uma cota de dinheiro por mês, então, alimentação é só para aquela pessoa. Então, já faz a [comida na] conta [certa]. Você faz, mas você não come.

Nos lugares onde os empregadores passaram em concursos também não come porque nesses casos os empregadores comem fora.

Têm condições [de comer fora], não têm nem mais fogão. Esses meninos me tratam como pessoa da família. Eles falam, nossa, você é a nossa segunda mãe aqui. Com eles, eu sou muito bem tratada, que são os meninos do Piauí que eu falo. Todos os meninos que eu trabalho são só do Piauí, só tenho um que é do Goiás.

Flávia lembra com carinho de quando os "meninos" chegaram para estudar na Universidade de Brasília.

Chegaram meninos, com dezessete anos, e hoje são homens, formados, trabalhando como funcionário público, passou em concurso. Então, eu tenho a lembrança boa de quando eles chegaram; uma lembrança boa de quando eu recebi. Eu falo, as crianças, porque hoje são uns homens maduros, adultos, com seus apartamentos, seu carro. Então, é uma lembrança boa lá atrás.

Como diarista ganha mais que no colégio. No colégio recebe salário; como diarista ganha cerca de R \$2.000,00 por mês. Flávia diz que por residências maiores pode-se cobrar até $\mathrm{R} \$ 150,00$ a diária. Mas não tem nenhuma de $\mathrm{R}$ \$ 150,00 atualmente porque o seu tempo é curto, então, tem que trabalhar em domicílios menores.

Dentre todos os trabalhos que teve, gostou mais de trabalhar na área de odontologia, mas acrescenta que "todos os trabalhos que faço é com amor, então, eu gosto de todos os meus trabalhos. Trabalho feliz, satisfeita".

Comparando o trabalho doméstico de diarista e mensal, Flávia diz que: 
a diária é mais pesada porque é uma faxina, é uma limpeza bem aprofundada. Então, vai acumulando trabalho no decorrer da semana que você tem que fazer tudo num dia só. Agora quando você trabalha por mês aí vai se organizando. Aí não acumula.

Por isso prefere o trabalho de mensalista, mas que tivesse a vantagem da remuneração melhor que tem como diarista. "Porque com meu estudo não consigo um trabalho que pague melhor. Então, eu teria que estudar mais. Diarista mais é questão financeira, né? Hoje as pessoas [que prestam esse serviço] estão optando por isso por causa do que ganham".

Já, entre a diária e o colégio, Flávia prefere:

para falar a verdade, a diária. Não é nem a questão do dinheiro. É o jeito de trabalhar. Eu trabalho mais livre. Eu faço o meu trabalho mais livre, entendeu? É um tipo de trabalho assim, eu chego, vejo o que tem para fazer, eu vou e faço. Aqui não, você está fazendo uma coisa, aí te tiram dali, te põem noutro canto e você nem faz uma coisa e nem outra. A desorganização, é isso que atrapalha, somente isso; que no meu trabalho eu me organizo. Que lá nas diárias eu chego e faço a minha organização, que eu tenho uma meta, que eu tenho uma meta a cumprir naquela casa. Aí eu chego lá me organizo, que eu vou fazer isso, isso e isso. Tal hora eu preciso ir embora. Então, eu tenho que fazer isso e isso e terminar, que eu preciso ir embora, deixar tudo ok. E aqui eu não tenho essa organização, não posso fazer essa organização. Porque tem alguém por trás de mim que faz. Só que é uma organização meio desorganizada.

A garantia da previdência social é a razão de optar por conciliar o trabalho como diarista com o que tem no colégio.

A idade tá chegando e chega uma certa idade em que você não consegue mais trabalhar como você trabalhava. A idade tá chegando, aí vai ficando mais difícil. Aí você não dá conta de trabalhar, você não pode ir no médico porque você não tem direito de ir no médico, porque não paga previdência social. Então, vai ser amparado por quem? Se adoecer não tem como você ser amparado. Um erro: poderia pagar, mas a gente não paga. Quando é particular acaba não pagando. Aí eu comecei a pensar muito nisso: "tenho que arrumar um trabalho fixo". E diarista hoje eu tenho. Amanhã os meninos entram de férias, viajam todos, eu fico sem nada. Pensei também nisso. Final de ano viaja todo mundo. Aí fecham as casas, aí viajam, passam um mês, dois [meses] fora. Que eu trabalho para universitários, suas famílias são todas de fora de Brasília. Aí passam dois, três meses fora, aí eu fico sem trabalhar. Mesmo nas casas em que trabalho há quatorze anos isso acontece. São ex-universitários. Já se formaram e hoje tem seus empregos aqui, mas viajam porque as famílias moram fora. Chega férias, vai. Passa um mês e eu fico um mês sem trabalhar nessa casa. Aí eu comecei a pensar na minha garantia de salário também. Como diarista ganha mais, mas tem os prós e os contras, porque você não tem uma garantia. Você vai viajar e eu trabalho na sua casa, sou diarista, aí você viaja, o meu dia vai ficar livre, mas eu fico presa a você, porque você viaja, passa um mês, quando você voltar eu estou ali disponível esperando para trabalhar. Penso também, em caso de doença, [para que,] se você adoecer, você tem uma segurança. Porque se eu adoecer, como diarista, eu não tenho segurança nenhuma. Eu não tenho salário. Se eu adoecer eu vou depender de alguém para cuidar de mim com dinheiro da pessoa. Já até pensei em pagar contribuição, mas só pensa e não vai atrás. 
Flávia diz que sua aposentadoria está garantindo guardando dinheiro para construir e alugar imóveis. Ela tem um lote em Planaltina. Vai construir quitinetes para alugar neles. A aposentadoria que ela vai garantir para si é essa. "Eu conto que minha aposentadoria vai ser as minhas casinhas alugadas". Todo o dinheiro que consegue economizar, reserva para isso.

\footnotetext{
"Eu sou muito de guardar o dinheiro porque eu penso lá na frente, eu penso na minha velhice. Tô trabalhando hoje para garantir o meu futuro na minha velhice. É um objetivo que eu tenho. Porque tenho o objetivo de fazer uma obra para poder alugar. Então, para poder fazer essa obra eu tenho que ir guardando um pouquinho de dinheiro. Às vezes eu abro mão de alguma coisa, alguma coisa que não vá me fazer falta. Comida não. Algo tipo uma roupa, um sapato. Se eu tenho um, para que que eu vou comprar o outro se eu posso deixar aquele dinheiro para poder comprar o material de construção. Eu penso assim, eu sou economista. Não pensava nisso quando trabalhava em casa de família mensal.
}

Flávia cultiva boas relações com as empregadoras. A primeira mulher para quem trabalhou é sua amiga até hoje. "A única que eu não tenho contato é a dona do consultório odontológico porque ela casou e foi embora".

Se pudesse ter outro trabalho seria secretaria, ou vigilante. Fez curso de vigilante para ver se conseguia um trabalho melhor. Ou, então, passar num concurso público para o qual pretende começar a estudar.

\subsection{Celina}

Flávia, a quem eu já havia entrevistado, adiantou para sua mãe, Celina, o assunto que me levava a lhe telefonar. Aceito o convite para participar da pesquisa, combinamos o dia e a hora em que eu deveria chegar na sua casa em Planaltina. A entrevista foi acompanhada atentamente pelo marido que, em princípio demonstrava alguma preocupação de que o nome de Celina fosse parar nos jornais, consequência de escândalos políticos deflagrados por gravações, mas não demorou a se tranquilizar e a demonstrar confiança. Celina, por sua vez, criticou o marido, justificando que a Flávia era uma moça inteligente e que jamais sugeriria a entrevista se eu não fosse confiável.

Celina mudou-se de Raul Soarez há 31 anos, então, com 42 anos. Os pais eram lavradores, tinham sítio, que foram vendendo na medida em que foram envelhecendo. Plantava feijão, milho, arroz. Também plantavam em terras de outros proprietários em regime de terça, no qual dão um terço da produção ao dono da terra. A mãe também trabalhava na lavoura. Quando lhe perguntei sobre cor Celina não se declarou branca; limitou-se a dizer 
"para mim não tem qualquer diferença, não". Celina e o marido mudaram-se para Brasília depois de o terceiro filho, militar, ter se estabelecido na cidade primeiro. Os irmãos e a mãe já moravam lá.

Tão logo chegou em Brasília, começou a trabalhar de diarista. "Sei que trabalhei foi muito aqui [na época em que me mudei]”. Trabalhava em duas casas. Naquela época não tinha máquina nem nada. "Tinha casa que botavam eu para fazer até comida, outras não. Outras eu trabalhava só lavando a roupa, passando, fazendo faxina”. Celina tinha que conciliar os afazeres com o cuidado de seus filhos, alguns ainda criança e outros já na adolescência.

\begin{abstract}
Quando eu cheguei aqui [em Brasília], em dia de sábado e domingo ainda lavava roupa da vizinha. Lavava a roupa dela toda e passava de noite, era no barracão de tábua que a gente morava, passava. Ainda passava as minhas, as dos meus filhos todos, eles estavam todos dentro de casa, fazia comida e cuidava de tudo em casa. Quando a gente é novo, é outra coisa. A gente tem mais força. Às vezes trabalhava três dias numa casa só, outras trabalhava dois dias numa casa só. Só sei que lá eu fazia comida, fazia tudo para eles. Lá eu cuidava de gente doente. Chegava lá, eles botavam eu para cuidar de gente doente, eu cuidava. Fazia de tudo e ganhando o mesmo salário de diarista. Eu era novata, eles aproveitavam de mim. Aproveitaram de mim foi muito. Já trabalhei em lugar que eles deixavam a pia da semana sem lavar nem uma vasilha. Sempre eles gostavam de acumular.
\end{abstract}

O único trabalho em que Celina só faz um tipo de tarefa é no que está atualmente, em que presta serviço quinzenalmente às sextas-feiras. "Mas nas outras casas tinha que cuidar de um lado e de outro. Foi muito tempo que eu passei assim. Depois que eu fui parando um pouquinho".

Uns três anos depois de chegar em Brasília foi se ambientando mais.

\begin{abstract}
Então, eu peguei serviço lá para o Plano que lá ganha mais. Eu fui arrumar jeito de ganhar mais, porque minha família era grande. As pessoas viam o meu trabalho, chamava e eu acabava indo. Via aquele que era melhor e passava para aquele que era o melhor. A gente tem que procurar o melhor, né? Aqui a gente trabalhava muito e ganhava pouco. Lá no Plano a gente ganhava melhor. A diferença era bem boa, que eles pagavam a passagem da gente e pagava a diária ainda.
\end{abstract}

Recorda das pessoas para quem trabalhou por mais tempo. "Tem a Vitória de trinta anos. Outra de nove anos, outra de cinco anos. As diárias era o dia todo. Ia para uma casa, passava o dia ali. Para dona Dita [a de nove anos] tinha dia que ficava até $7 \mathrm{~h}$ da noite. Mas ela era boa para mim, me dava muita coisa".

Continuar trabalhando, para Celina, traz significados que passam ao largo do valor monetário que recebe pelo seu serviço. "Posso estar cansada e quando alguém me chamava 
para trabalhar eu levanto e de repente eu não estou cansada mais. E aí tudo vai embora. Parece que é uma força que me ajuda".

Quando Celina teve um "começo de derrame" ficou sem trabalhar um mês, mas não aguentou ficar em casa. "Fui ficando fraca, mas aí o médico falava 'se você ficar quieta é pior, você tem que fazer muito exercício'. Escutando o médico falar, assim, eu continuava limpando parede na casa dos outros, areando vasilha, esfregando roupa. Fazendo isso fui melhorando".

Celina nunca trabalhou fichada, nunca teve folga. Pagava contribuição por conta própria. Começou a pagar o INSS três anos antes de se aposentar.

Quando eu era mais nova pensava que tinha que trabalhar fichada para aposentar. Depois que eu descobri que se eu pagasse o INSS a gente aposentava, eu fiz a inscrição do INSS, continuei pagando os carnês e nem pensei naquilo mais não. [Pensou] 'ah, não vou trabalhar fichada mais não, desse jeito mesmo tá bom'.

Começou a pagar os carnês com mais de 50 anos. Por volta dos 55 foi que teve o começo de derrame. A necessidade manter-se em atividade não explica que Celina continue com a única diária que ainda realiza. Ela não tem dificuldade em se manter ocupada por outros meios.

Eu trabalho muito ainda, cuido dessa casa minha que é enorme, cuido da casa da minha mãe Na casa da minha mãe, meu irmão mora lá com ela, mas ele é homem, ele deixa as coisas todas descuidadas. Se eu não for lá cuidar, fica tudo imundo. Então, eu vou todo dia lá dar uma cuidadinha nas coisas, deixo tudo em ordem.

Católica vicentina, dona Celina ainda cuida de crianças carentes ajudando a fazer e a servir lanche para elas na paróquia. Além de tudo isso, ainda vai quinzenalmente cuidar da casa de Vitória Cristina.

$\mathrm{Eu}$, por mim, continuo trabalhando que eu não sei ficar parada. Acho que ficar parada é pior. Se eu puder ficar à toa de tudo eu não faço. Me falam: "Celina você é boba demais, você é aposentada. Por que você ainda vai no Plano trabalhar?" "Eu vou por amizade que eu tenho a minha patroa". Ela tem eu como se fosse gente da família. Então, eu não posso deixar ela na mão. Eu vou lá e ajudo ela. E ela é mais nova do que eu. Aposentou agora esse ano. Tá com 55 anos. O marido dela também é mais novo do que eu.

A Vitória é a sua única cliente. Mas ao que tudo indica, os mais de trinta anos de relacionamento com Celina fizeram a patroa manter a relação por questões outras que passam ao largo do trabalho feito pela Celina. 
Eu ia lá toda semana, mas a Vitória aposentou e diminuiu o salário dela. Ela me pagava R\$ 120,00 por dia. "Mas eu não posso mais te pagar toda semana, então, você vem de quinze em quinze dias", [ela disse]. [Hoje] eu chego lá e tenho que pensar em que é que eu vou fazer, porque a casa já é tão limpinha. Porque ela é muito cuidadosa, deixa tudo cuidadinho. Chego limpo os vidros, limpo os banheiros, a cozinha, areio os azulejos. Cinco horas já limpei tudo, ainda passo a roupa dela. A roupa dela é pouquinha. Chego lá $9 \mathrm{~h}$ da manhã saio as $5 \mathrm{~h}$.

A mãe, com 94 anos, não anda mais. Ao falar dos seus sonhos Celina diz: "sabe o que é que eu sonho? Sonho que o dia que chegar minha hora, Deus me dê uma boa hora, que não me deixe ficar de cadeira de rodas igual a minha mãe". Celina se sente realizada, já casou seus filhos todos, diz. Hoje em dia só deseja que todos eles sejam bastante felizes. 


\section{TRABALHO DOMÉSTICO MENSAL: CRIANDO SENSIBILIDA- DES}

Aqui serão enfocadas questões que estão em jogo e que se colocam para trabalhadoras domésticas em três momentos: na migração, na prestação de serviço como mensalista e como diarista. Tendo em vista que está-se falando do trabalho doméstico no Distrito Federal, executado na quase totalidade por trabalhadoras migrantes, as implicações pertinentes às relações entre famílias, rendimento e direitos começam a se delinear antes das relações no trabalho propriamente, já que o processo de migração que o antecede influencia as configurações do trabalho doméstico e traz à tona elementos que desembocam no modo como o avalia, que se traduz no esforço de identificação que têm com o trabalho.

A prática do esforço de identificação deriva das conquistas trazidas desde a migração, das relações afetivas cultivadas no trabalho e da busca por estabilidade em atenção às necessidades da família. Embora esses três elementos tenham ficado mais visíveis na abordagem aqui feita na migração, no trabalho doméstico mensal e no trabalho da diarista respectivamente, eles são, de fato, cumulativos.

A intenção aqui é chegar onde a lei não chegou - no trabalho da diarista - e apontar as consequências dos quase inexistentes direitos que diaristas possuem ("quase inexistentes" tanto pela ainda baixa adesão a contribuição previdenciária quanto pelo fato de que, quando contribuem, tem direitos restritos).

Se os riscos que o trabalho doméstico sem direitos traz, especialmente para diaristas, é o de ocultar quaisquer outras dimensões que não seja a do ser para o trabalho, as trajetórias delas recolocam outras dimensões nas motivações que buscam pela preocupação com própria família e no relacionamento que nutrem com a família empregadora.

A migração de trabalhadoras domésticas traz para as entrevistadas conquistas não só do ponto de vista econômico, mas também traz a possibilidade de adquirir independência e de reconstruírem suas vidas num lugar distante motivadas pelas mais variadas razões. Muitas vezes o custo dessas conquistas é a separação dos próprios filhos que, no entanto, na maior parte das vezes são reunidos quando as trabalhadoras passam a condição de diaristas.

\subsection{MIGRAÇÃO: FACES DA BUSCA POR MELHORES CONDIÇõES DE VIDA}

No Distrito Federal, praticamente todas as trabalhadoras domésticas são migrantes vindas de outras unidades da federação. Cleide e o marido Simão apontam de que modo 
dinâmicas que articulam migração e êxodo rural pavimentaram o caminho que a leva ao trabalho doméstico. A partir disso, pode-se entender o que significa a migração nesse contexto.

Simão, zelador de um prédio da Asa Norte, fala do motivo de sua mudança para Brasília. Simão trabalhava na roça em Santa Quitéria e Sobral, no Ceará.

Em 87, 88 sai de Brasília para ir para São Paulo porque o salário de lá era maior. Passei um tempo aqui [em Brasília] e voltei de novo para o Ceará, para Santa Quitéria. Aí fui embora para São Paulo em 1989. Fiquei em São Paulo 17 anos. De São Paulo voltei de novo para o Ceará, para Sobral, de Sobral eu fui para o Rio de Janeiro, em 1999. Eu saí do Rio de Janeiro de 2001 para 2002, eu voltei de novo para Santa Quitéria. Era um ziguezague que a gente fazia na vida que só Deus e nós encontrava o nosso caminho de volta. Mas quando saí de Brasília já sabia que ia para São Paulo. Sai de São Paulo porque a vida lá tava muito difícil. Era uma vida muito apertada, muito sofrida. Trabalhava muito e ganhava pouco e a gente tem que procurar o que traz melhora para gente. Saí nesse mundo de meu Deus atrás de alguma coisa melhor na vida e a gente acabou encontrando um lugar melhor que foi Brasília, para gente se estabelecer. E até hoje estamos aqui e pretendemos ficar até o dia que Deus der saúde (...). [Sempre voltava à Santa Quitéria ou para Sobral] era vendendo farinha. Querendo tentar ver se dava certo a vida lá, não sabe? Nós voltava sempre. A gente é assim, a gente vem ganhar dinheiro e volta para sua própria terra natal e coloca um comercinho e ver se dá para você viver. Mas, naquele tempo, começou o tempo escasso de chuva, não tinha como você..., sabe? Porque lá é bom quando chove, que você planta, tem muita coisa, as suas colheitas de milho, feijão, arroz. Mas quando não chove a gente não vai tendo aquele campo para você trabalhar. Sem estudo, não tinha planejamento nenhum, só na roça mesmo, naqueles pau-de-arara. Aí não dava, aí a gente voltava de novo para as melhoras de novo na capital. E a gente continuava assim, até encontrar um lugar que você pudesse se estabelecer e pudesse criar sua família. E onde a gente se estabeleceu foi aqui em Brasília. Se desse certo [de ficar na região de origem], a gente jamais sairia do nosso lugar, né? Mas espero que algum dia dê certo de a gente voltar lá. Eu pretendo, com os meus 65 anos, voltar para lá porque aí não preciso mais trabalhar. É só ir no banco pegar meu dinheirinho todo mês. Não vou precisar mais correr atrás de nada, não.

O marido de Celina também trabalhava na roça em Minas gerais. Não teve a mesma história de vida itinerante de Simão. Mudou-se para o Distrito Federal quando o filho já estava bem estabelecido na capital e a sogra também já tinha se mudado para lá. Por mais que a migração lhe tenha sido substancialmente mais suave do que foi para Simão, as razões, no entanto, são as mesmas: deixar a vida dura da "roça".

Embora essas duas histórias de vida tenham mais semelhança, se verifica que a de outras entrevistadas também se aproximam na medida em que mostram a transição geracional de pais lavradores para filhas e genros que, com expectativas de vida diferentes da dos pais, foram para a cidade grande. Foi o mesmo caso de Cecília, Antônia e Flávia (filha de 
Celina). Ângela e Celina, elas próprias fizeram essa transição e mudaram-se para a capital, atitude que só foi possível por já terem familiares em Brasília.

Cleide traz um elemento adicional que articula campo e trabalho doméstico: a questão da escolaridade.

Terminei o ensino médio. Estudei trabalhando uns sete anos. Eu já comecei tarde a estudar. Morava na cidade do interior. Os pais não tinham conhecimento nenhum, então, a gente estudou até a quarta série em escola de fazenda. Nessa época o governo não tinha nada, plano nenhum. Hoje eu vou lá onde morei: não tem mais pessoas como eu fui criada que estudavam só até a quarta série porque não tinham oportunidade de estudar na cidade, porque não tinha transporte. Tinha que pagar do bolso, meu pai não tinha condições de pagar, aí a gente ficou sem estudar. Estudava só o que tinha na fazenda. Hoje não, hoje o carro vai pegar na porta. Todo esse pessoal que mora em chácara terminou seus estudos, outros estão fazendo faculdade porque o governo pagava tudo. A gente não teve essa oportunidade.

O relato de Cleide mostra as limitações que morar em fazenda impunha aos estudos. Sem poder estudar, a incorporação ao mercado de trabalho é feita a partir de profissões feminizadas, cuja habilidade é atribuída a natureza feminina e, portanto, dispensando qualquer aprendizado. $\mathrm{O}$ trabalho doméstico tem como caraterística distintiva a baixa escolaridade das mulheres que se dedicam a ele (ver tabela 4).

Tabela 4: NÍVEL DE INSTRUÇÃO FORMAL DE TRABALHADORAS NO MERCADO DE TRABALHO (EM \%) - BRASIL

\begin{tabular}{|c|c|c|c|c|c|c|c|c|c|}
\hline Grupamentos ocupacionais & sem & fi & fc & mi & me & si & sc & nd & Total \\
\hline Dirigentes em geral & 0,89 & 6,54 & 4,6 & 2,43 & 30,18 & 9,79 & 45,47 & 0,11 & 100 \\
\hline $\begin{array}{l}\text { Profissionais das ciências e das } \\
\text { artes }\end{array}$ & 0,6 & 2,43 & 1,2 & 0,8 & 8,12 & 10,96 & 75,81 & 0,08 & 100 \\
\hline Técnicas de nível médio & 0,64 & 2,5 & 2,58 & 3 & 55,52 & 12,63 & 22,93 & 0,19 & 100 \\
\hline $\begin{array}{l}\text { Trabalhadoras de serviços admi- } \\
\text { nistrativos }\end{array}$ & 0,46 & 3,45 & 4,78 & 6,81 & 51,45 & 14,77 & 18,14 & 0,15 & 100 \\
\hline Trabalhadoras dos serviços & 4,19 & 27,83 & 14,69 & 9,14 & 36,93 & 3,14 & 3,64 & 0,44 & 100 \\
\hline $\begin{array}{l}\text { prestadoras de ser- } \\
\text { cio }\end{array}$ & 3,25 & 19,08 & 10,2 & 9,36 & 45,66 & 5,6 & 6,44 & 0,41 & 100 \\
\hline Trabalhadoras agrícolas & 20,87 & 54,38 & 786 & 388 & 105 & 0,6 & 153 & 0,38 & 100 \\
\hline $\begin{array}{l}\text { Trabalhadoras da produção de } \\
\text { bens e serviços e de reparação e } \\
\text { manutenção }\end{array}$ & 3,46 & 30,25 & 14,08 & 8,38 & 37,54 & 2,61 & 3,3 & 0,38 & 100 \\
\hline $\begin{array}{l}\text { Membros das forças armadas e } \\
\text { auxiliares }\end{array}$ & 0 & 0 & 1,7 & 1,59 & 30,86 & 8,43 & 57,41 & 0 & 100 \\
\hline Ocupações maldefinidas & 0 & 10,1 & 0 & 0 & 33,41 & 6,78 & 49,7 & 0 & 100 \\
\hline Trabalhadoras domésticas & 8,57 & 45,34 & 15,39 & 7,51 & 20,72 & 0,85 & 1,13 & 0,49 & 100 \\
\hline
\end{tabular}

Legenda: sem (sem instrução); fi (ensino fundamental incompleto); fc (ensino fundamental completo); mi (ensino médio incompleto); mc (ensino médio completo); si (superior incompleto): sc (superior completo); nd (não determinado).

Fonte: microdados PNAD 2014. Elaboração própria. 
Conforme a tabela acima mostra, mais da metade das trabalhadoras domésticas possui o nível fundamental incompleto. Aproximadamente $70 \%$ das trabalhadoras domésticas possui, no máximo, o nível fundamental completo. É o segundo grupamento ocupacional com menor escolaridade (as trabalhadoras agrícolas são o primeiro). Entre as mulheres entrevistadas, com exceção de Érica e de Zélia, todas saíram de zonas rurais, com a família ou sozinhas.

Questões pertinentes à escolaridade chamam atenção pela mudança que têm apresentado nos últimos anos.

Tabela 5: VARIAÇÃO DA ESCOLARIDADE DE TRABALHADORAS DOMÉSTICAS ENTRE 2002 E 2014 (EM \%) - BRASIL

\begin{tabular}{|l|r|r|}
\hline \multicolumn{1}{|c|}{ Anos de estudo $^{\mathbf{4 3}}$} & $\mathbf{2 0 0 2}$ & $\mathbf{2 0 1 4}$ \\
\hline Sem instrução e menos de 1 ano & 10,61 & 8,57 \\
\hline 1 ano & 2,98 & 2,28 \\
\hline 2 anos & 5,79 & 3,51 \\
\hline 3 anos & 9,08 & 5,07 \\
\hline 4 anos & 18,6 & 13,75 \\
\hline 5 anos & 12,07 & 9,44 \\
\hline 6 anos & 7,02 & 5,41 \\
\hline 7 anos & 6,97 & 5,81 \\
\hline 8 anos & 11,54 & 15,45 \\
\hline 9 anos & 3,05 & 3,94 \\
\hline 10 anos & 2,88 & 3,56 \\
\hline 11 anos & 7,91 & 19,58 \\
\hline 12 anos & 0,21 & 1,33 \\
\hline 13 anos & 0,06 & 0,19 \\
\hline 14 anos & -- & 0,25 \\
\hline 15 anos ou mais & 0,04 & 1,36 \\
\hline Não determinados e sem declaração & 1,2 & 0,49 \\
\hline Total & 100,00 & 100,00 \\
\hline
\end{tabular}

Fonte: microdados PNAD 2002 e 2014. Elaboração própria.

\footnotetext{
${ }^{43}$ Segundo a PNAD, "a classificação segundo os anos de estudo foi obtida em função da série e do grau que a pessoa estava frequentando ou havia frequentado, considerando a última série concluída com aprovação. A correspondência foi feita de forma que cada série concluída com aprovação correspondeu a um ano de estudo. A contagem dos anos de estudo teve início em um ano, a partir da primeira série concluída com aprovação de curso de primeiro grau ou elementar; em cinco anos de estudo, a partir da primeira série concluída com aprovação de curso de médio primeiro ciclo; em nove anos de estudo, a partir da primeira série concluída com aprovação de curso de segundo grau ou de médio segundo ciclo; e em 12 anos de estudo, a partir da primeira série concluída com aprovação de curso superior. As pessoas que não declararam a série e o grau ou com informações incompletas ou que não permitissem a sua classificação foram reunidas no grupo de anos de estudo não determinados ou sem declaração". Disponível em http://www.ibge.gov.br/home/estatistica/populacao/mapa_mercado_trabalho/notastecnicas.shtm. Se devidamente somado, poderá ser notada uma diferença nas casas decimais entre essa tabela e a anterior para níveis correspondentes de escolaridade devido ao fato de que foram usadas variáveis diferentes da PNAD. O ano de 2002 não tem a variável que agrupa os anos de estudo em ciclos como na tabela anterior, então, se utilizou outra variável que apresentasse dados comparáveis para os anos de 2002 e 2014 presentes nesta última tabela.
} 
A tabela acima aponta o aumento de escolaridade das trabalhadoras domésticas. Ao passo que reduziu o percentual de mulheres com no máximo sete anos de estudo, que equivale ao penúltimo ano do primeiro grau, o percentual daquelas com no mínimo primeiro grau completo passou de $25,69 \%$ para 45,66\%. Só o total de mulheres com o segundo grau mais que duplicou passando de $14,15 \%$ para 30,21\%. Como dito anteriormente, tem decrescido a importância dos serviços domésticos remunerados para inserção de mulheres no mercado de trabalho, sendo concomitante, portanto, ao aumento de escolaridade de trabalhadoras domésticas. Como o aumento de escolaridade demonstrado na última tabela afeta não apenas trabalhadoras domésticas, mas também mulheres em condição social semelhante (ainda que não sejam trabalhadoras domésticas), pode-se concluir que o aumento de escolaridade cumpriu papel importante nesse processo.

Comumente, como se nota nas entrevistas, o êxodo rural se mostra articulado ao deslocamento entre unidades da federação. Não é possível, a partir da coleta quantitativa de dados da PNAD, que será utilizada aqui, diferenciar entre o fluxo migracional de mulheres e o fluxo nos quais elas dividem o protagonismo da decisão de migrar com familiares (geralmente marido); bem como não é possível também dar um conteúdo mais específico para o termo "migrar" que não seja simplesmente "residir em município (ou estado) diverso do (município ou estado) de nascimento". Então, uma criança que se muda com os pais de cidade e no futuro se torne trabalhadora doméstica, a partir dessa coleta de dados, é uma migrante que não se distingue de uma mulher adulta que saia de uma cidade pequena para trabalhar na cidade grande no mesmo serviço. Por mais que, do ponto de vista em que se associa a migração ao alargamento ou rompimento de laços afetivos e a distanciamento de amigos e parentes, o primeiro caso esteja mais próximo do caso de uma não-migrante e o segundo esteja mais próximo do caso de uma migrante, a partir desse método de coleta de dados, ambos são indistintos.

Os principais estados de onde essas trabalhadoras partem são: Bahia, 19,63\%; Minas Gerais, 15,9\%; Paraná, 9,58\%; Pernambuco, 7,01\%; Maranhão, 5,5\% e São Paulo, 5,42\% (para restringir aos Estados que apresentam esse percentual superior de 5\%). O Estado de São Paulo é o que mais emprega trabalhadoras do setor, 23,43\% dela; seguido de Minas, 11,76\%; Rio de Janeiro, 10,28\%; Bahia, 7,48\%; e Rio Grande do Sul, 6\%.

A peculiaridade de Brasília, nesse aspecto, é de ser a unidade da federação que possui o maior percentual de trabalhadoras domésticas de fora do estado, aproximadamente $84,3 \%$ 
(ver tabela 6). Isso se deve, em parte, ao fato de ser uma cidade relativamente nova e de ter contado (e ainda contar) com processos de ocupação territorial extremamente desfavorável para populações de baixa renda ${ }^{44}$. As trabalhadoras domésticas de Brasília, na sua maior parte, são nascidas na Bahia, 17,4\%; Piauí, 16,6\%; Maranhão, 14,98\%; Minas Gerais, 12,55\%; Ceará, 10,93\% e Goiás, 10,52\%, para restringir aos estados que apresentam mais de $5 \%$ de migrantes para o Distrito Federal.

Tabela 6: TAXA DE MIGRAÇÃO DE TRABALHADORAS DOMÉSTICAS DE ACORDO COM O ESTADO DE RESIDÊNCIA - BRASIL

\begin{tabular}{|c|c|c|c|c|}
\hline Estado de residência & $\begin{array}{l}\text { moradoras na cidade } \\
\text { de nascimento }\end{array}$ & $\begin{array}{l}\text { moradoras no estado } \\
\text { de nascimento }\end{array}$ & $\begin{array}{l}\text { moradoras fora do } \\
\text { estado de nasci- } \\
\text { mento }\end{array}$ & Total \\
\hline Rondônia & 25,87 & 13,53 & 60,6 & 100 \\
\hline Acre & 46,67 & 31,85 & 21,48 & 100 \\
\hline Amazonas & 43,93 & 38,49 & 17,57 & 100 \\
\hline Roraima & 22,03 & 10,17 & 67,8 & 100 \\
\hline Pará & 50,55 & 29,96 & 19,49 & 100 \\
\hline Amapá & 32,91 & 13,93 & 53,17 & 100 \\
\hline Tocantins & 42,51 & 26,35 & 31,14 & 100 \\
\hline Maranhão & 52,85 & 38,86 & 8,29 & 100 \\
\hline Piauí & 60,71 & 27,98 & 11,31 & 100 \\
\hline Ceará & 57,76 & 37,12 & 5,13 & 100 \\
\hline Rio Grande do Norte & 55,26 & 36,84 & 7,9 & 100 \\
\hline Paraíba & 59,88 & 29,34 & 10,78 & 100 \\
\hline Pernambuco & 64,49 & 29,49 & 6,02 & 100 \\
\hline Alagoas & 56,2 & 39,42 & 4,38 & 100 \\
\hline Sergipe & 56,34 & 31,64 & 12,02 & 100 \\
\hline Bahia & 59,64 & 33,26 & 7,1 & 100 \\
\hline Minas Gerais & 52,57 & 37,86 & 9,57 & 100 \\
\hline Espírito Santo & 40,5 & 30,5 & 29 & 100 \\
\hline Rio de Janeiro & 56,53 & 19,51 & 23,96 & 100 \\
\hline São Paulo & 31,53 & 23,51 & 44,95 & 100 \\
\hline Paraná & 36,5 & 47,27 & 16,23 & 100 \\
\hline Santa Catarina & 39,45 & 35,32 & 25,23 & 100 \\
\hline Rio Grande do Sul & 49,41 & 44,82 & 5,78 & 100 \\
\hline Mato Grosso do Sul & 36,04 & 25,22 & 38,74 & 100 \\
\hline Mato Grosso & 33,64 & 21,82 & 44,54 & 100 \\
\hline Goiás & 34,13 & 28,14 & 37,73 & 100 \\
\hline Distrito Federal & 15,01 & 0,68 & 84,3 & 100 \\
\hline Total & 45,61 & 30,29 & 24,1 & 100 \\
\hline
\end{tabular}

Fonte: microdados PNAD 2014. Extração própria.

\footnotetext{
${ }^{44}$ Para mais, ver: Nunes (1999, 2000a, 2000b, 2000c - documentários); Nunes, Magalhães, Paiva-Chaves (1993, 1995 - documentários); Magalhaes (1988 - documentário). Esses documentários estão disponíveis no Acervo do NECOIM/CEAM/UnB (Núcleo de Estudos da Cultura, Oralidade, Imagem e Memória do Centro de Estudos Avançados Multidisciplinares da Universidade de Brasília). É possível encontrar o telefone na internet. Esses documentários trazem momentos mais agudos de confronto entre a população local e os poderes públicos por direitos sociais. Em outra vertente, Borges (2004), mostra de que forma práticas políticas são tecidas na busca pelo direito ao lote para a construção da moradia, num processo que questiona o que convencionalmente se entende por clientelismo.
} 
Quanto aos Estados que recebem as trabalhadoras, estabelecendo como parâmetros 1) o salário mínimo nacional e 2) as médias de rendimento de diaristas e mensalistas, podese distinguir quatro grupos de faixas salariais: 1) o Distrito Federal, 2) os estados com salário mínimo próprio, 3) os estados da região Centro-Oeste e 4) os demais estados. O Distrito Federal apresentou melhores salários para trabalhadoras domésticas dentre todos os estados do país, de acordo com dados da PNAD 2014, tanto para diarista, R $\$ 1.050,00$, quanto para mensalistas, R\$ 867,00. Episodicamente, como em $2013^{45}$, o rendimento de mensalistas pode superar a de diaristas, no entanto, continuam entre médias as mais altas.

Tabela 7: ESTADOS QUE APRESENTAM MÉDIA DE RENDIMENTO DE DIARISTAS E MENSALISTAS SUPERIOR À NACIONAL OU SUPERIOR AO SALÁRIO MÍNIMO (EM R\$) - BRASIL

\begin{tabular}{|l|r|r|r|}
\hline Esdados & diaristas & Mensalistas & piso salarial \\
\hline Rio de Janeiro & 841,11 & 782,67 & 824,76 \\
\hline São Paulo & 921,60 & 837,41 & 810,00 \\
\hline Paraná & 916,54 & 701,79 & 983,40 \\
\hline Santa Catarina & 969,47 & 774,04 & 835,00 \\
\hline Rio Grande do Sul & 853,10 & 733,56 & 868,00 \\
\hline Mato Grosso do Sul & 747,03 & 621,94 & 724,00 \\
\hline Mato Grosso & 750,23 & 666,44 & 724,00 \\
\hline Goiás & 735,23 & 667,14 & 724,00 \\
\hline Distrito Federal & 1050,46 & 867,26 & 724,00 \\
\hline Salário mínimo: R\$ 724,00. Renda média de diaristas: R\$ 761,00. Renda média de mensalistas: R\$ 649,00. \\
Fonte: microdados PNAD 2014. Extração própria.
\end{tabular}

Depois do Distrito Federal, quatro dos cinco estados com piso salarial próprio apresentaram rendimentos superiores a um salário mínimo nacional (que era $\mathrm{R} \$ 724,00$ em 2014) nos dois segmentos do trabalho doméstico (diário e mensal), no entanto, excepcionalmente esses rendimentos foram superiores ao mínimo estipulado para os respectivos Estados. Nesses estados (Rio de Janeiro, São Paulo, Paraná, Santa Catarina, Rio Grande do Sul, onde o salário mínimo próprio ficou entre $\mathrm{R} \$ 810,00$ (SP) e $\mathrm{R} \$ 983,00$ (PR) em 2014) as médias de rendimento para diaristas variaram entre $\mathrm{R} \$ 841,00$ (RJ) e $\mathrm{R} \$ 969,00$ (SC) e, para mensalistas, entre R \$ 701,00 (PR) e R \$ 837,00 (SP). O Paraná foi o único que apresentou uma média rendimento inferior a um salário mínimo nacional no caso das mensalistas. As trabalhadoras domésticas dos dois seguimentos em São Paulo e as diaristas de Santa Catarina e do Rio de Janeiro foram as que apresentaram médias de rendimento superiores ao mínimo estipulado em seus estados $(\mathrm{R} \$ 810,00, \mathrm{R} \$ 835,00$ e $\mathrm{R} \$ 824,76)$.

\footnotetext{
${ }^{45}$ Fonte: microdados PNAD 2013.
} 
Os estados do Centro-Oeste apresentaram médias de rendimento para diaristas concomitantemente superior ao salário mínimo nacional, mas inferior à média de rendimento de diaristas no país que foi de $\mathrm{R} \$ 761,00$, para 2014. Já o rendimento de mensalistas nesses estados foi pouco superior à média nacional para esse grupo, $\mathrm{R} \$ 649,00$, não alcançando o salário mínimo nacional. A única exceção é Mato Grosso do Sul, cuja média é de R \$ 621,00, portanto, inferior à média nacional de rendimento de mensalistas.

Quanto aos demais estados, nos dois seguimentos do trabalho doméstico apresentaram médias de rendimento inferior tanto ao salário mínimo nacional, quanto às médias do respectivo seguimento.

Outro fator que deve ser notado é que, de acordo com a PNAD, inequivocamente trabalhadoras domésticas, quando migrantes, apresentam melhores percentuais de contribuição previdenciária (44,96\% do total de migrantes, contra 33,64\% do total de residentes no município de nascimento), carteira de trabalho assinada $(34,06 \%$, contra $25,71 \%)$ que as trabalhadoras que residem no mesmo lugar, mas que não são migrantes. Em relação às médias salariais, também as migrantes apresentam melhores rendimentos que as demais nascidas na mesma cidade em que trabalham, com médias de $\mathrm{R} \$ 747,31$ e R \$608,06.

Convém sublinhar o papel que o Distrito Federal tem nesse cenário. "Inaugurado" expressão estranha nesse contexto para a maioria dos pessoas - em 1960, o Distrito Federal é, entre as 12 capitais mais populosas, o segundo que mais cresce populacionalmente desde a década de $1980^{46}$ (esse ano de referência foi escolhido em relação ao tempo de moradia das entrevistadas no Distrito Federal), tendo crescido 69,8\% entre 1980 e 2000 (para nos atermos ao período de migração citado nas entrevistas; se considerado a data final de 2010, esse percentual sobe para $113,6 \%)^{47}$. Sendo concomitantemente a Unidade da Federação com maior renda per capita e o com maior Índice de Gini, que significa que é o mais desigual do país, condições propícias para a proliferação de empregos domésticos.

Embora tenha nascido a partir de propostas de planejamento baseadas no comprometimento arquitetônico com a ideologia dita socialista e na negação da estratificação existente na sociedade brasileira, Brasília materializa em si "o mesmo processo de urbanização generalizada, presente nas empobrecidas metrópoles brasileiras" (PAVIANI, 2010, p.97)17. Aldo Paviani (2010) caracteriza a região como um conjunto heterogêneo, que engloba o Plano Piloto (espaço privilegiado da

\footnotetext{
${ }^{46}$ De acordo com dados do site http://www.oeco.org.br/blogs/oeco-data/27232-as-capitais-brasileiras-quemais-cresceram-no-ultimo-seculo/.

${ }^{47}$ Nos dois casos apenas Manaus apresentou taxa de crescimento populacional maior.
} 
classe dominante) e as Regiões Administrativas (anteriormente denominadas cidades-satélites e onde se concentram cerca de $3 / 4$ do contingente populacional do DF), favelas, invasões e também a periferia goiana, todas vinculadas funcionalmente ao centro urbano, Brasília, onde estão concentradas as ofertas de trabalho, as melhores atividades e equipamentos. Como resultado desses aspectos, há o deslocamento de grande parte da população periferizada, especialmente as trabalhadoras domésticas, que viaja ao centro diariamente para trabalhar ou em busca de serviços de saúde, lazer etc. (VIEIRA, 2014, p. 24)

Assim, a migração traz questões de ordem econômica que se tornaram decisivas e em face das quais as entrevistadas valorizam sua trajetória de vida, apesar do Distrito Federal reproduzir, em seu interior, estratificação que remete àquela existente entre regiões ou unidades da federação de menor e de maior poder aquisitivo. Nesse sentido, o esforço de identificação de trabalhadoras domésticas com seu trabalho resulta da perspectiva que tem sobre a própria história e da importância do que conquistaram na vida em relação ao que antes tinham, tema que vai além de questões econômicas, como mostra o próximo tópico.

Apesar dessas possibilidades e potencialidades oferecida pela migração de trabalhadoras domésticas, ela também apresenta pelo menos um aspecto extremamente deletério. Figueiredo (2011) expõe como crianças e adolescentes do interior da Bahia são levadas de suas famílias para trabalhar em casas da capital. O intuito das crianças e adolescentes e de seus familiares é que as meninas, na capital, tivessem condições melhores do que teriam se continuassem com as suas famílias pobres e que pudessem estudar. No entanto, a imaturidade dessas meninas é intensificada pelo fato de estarem longe da sua rede familiar e de amigos, o que as coloca à mercê das famílias em cuja residência vão morar ${ }^{48}$. Se não se pode afirmar que intencionalmente se busca a vulnerabilização dessa criança ou adolescente, parece haver aí uma tentativa de controle dessa estranha que, afinal, vai dividir o ambiente doméstico.

No contexto da migração, pelo menos temporariamente, há uma limitação na rede de relacionamentos da trabalhadora ao contexto do trabalho (com o tempo, as redes para além da esfera estrita pertinente ao trabalho tendem a ser refeitas, como várias experiências aqui mostram), situação que tende a ser mais marcada se a trabalhadora é doméstica residente e é tanto mais acentuada quanto mais jovem é a trabalhadora. Nessa medida, um fenômeno recente presente em quase todos os estudos sobre o tema, o envelhecimento das trabalhado-

\footnotetext{
${ }^{48}$ Bernardino-Costa (2011) constata dinâmicas semelhantes do Distrito Federal.
} 
ras domésticas, se articula de forma positiva a migração. Na tabela abaixo, é possível perceber que na faixa de até 34 anos houve uma diminuição percentual de trabalhadoras domésticas. Tendencialmente essa diminuição é mais expressiva quanto menor a faixa etária. Inversamente, a partir dos 35 anos, aumenta a variação percentual de trabalhadoras domésticas à medida que aumenta a faixa de idade.

Tabela 8: VARIAÇÃO DA IDADE DAS TRABALHADORAS DOMÉSTICAS ENTRE 2002 E 2014 (EM $\%)$ - BRASIL

\begin{tabular}{|l|r|r|r|r|r|r|}
\hline \multicolumn{1}{|c|}{ Idade } & \multicolumn{2}{|c|}{$\mathbf{2 0 0 2}(\mathbf{\%})$} & \multicolumn{2}{|c|}{$\mathbf{2 0 1 4}(\mathbf{\%})$} & \multicolumn{2}{c|}{ variação do percentual } \\
\hline de 10 a 14 anos & diarista & mensalista & diarista & mensalista & \multicolumn{1}{c|}{ diarista } & Mensalista \\
\hline de 15 a 19 anos & 0.81 & 2.32 & 0.4 & 1 & -50.62 & -56.90 \\
\hline de 20 a 24 anos & 4.9 & 12.71 & 1.37 & 4.77 & -72.04 & -62.47 \\
\hline de 25 a 29 anos & 7.97 & 14.57 & 3.35 & 6.16 & -57.97 & -57.72 \\
\hline de 30 a 34 anos & 11.73 & 13.26 & 6.4 & 7.42 & -45.44 & -44.04 \\
\hline de 35 a 39 anos & 14.82 & 12.68 & 11.91 & 11.5 & -19.64 & -9.31 \\
\hline de 40 a 44 anos & 16.97 & 13.18 & 14.84 & 13.79 & -12.55 & 4.63 \\
\hline de 45 a 49 anos & 15.69 & 11.88 & 17.6 & 14.18 & 12.17 & 19.36 \\
\hline de 50 a 54 anos & 10.4 & 8.31 & 15.21 & 14.17 & 46.25 & 70.52 \\
\hline de 55 a 59 anos & 8.25 & 5.5 & 13.33 & 11.7 & 61.58 & 112.73 \\
\hline mais de 60 anos & 4.64 & 2.84 & 8.85 & 8.62 & 90.73 & 203.52 \\
\hline Total & 3.84 & 2.74 & 6.74 & 6.69 & 75.52 & 144.16 \\
\hline Fon & 100 & 100 & 100 & 100 & & \\
\hline
\end{tabular}

Fonte: microdados PNAD 2002 e 2014. Elaboração própria.

Esse fator é relevante por duas razões: em primeiro lugar pela redução na participação no mercado de trabalho de crianças e adolescentes que, ao se empregarem, não estão simplesmente executando uma atividade que demanda tempo; estão fazendo uma atividade que interfere do desenvolvimento motor considerado adequado por impedi-las de adquirir experiências necessárias que teriam brincando ou estudando, em vez de se tornarem pessoas responsáveis muito cedo. Paralelamente, ao trabalharem em vez de estarem estudando, crianças e adolescentes deixam de desfrutar o convívio com pessoas de sua faixa etária, razão porque essa atividade é experimentada como mutilação (FIGUEIREDO, 2011: 96-98). Além das consequências para o desenvolvimento emocional, afetivo, físico e intelectual "crianças e adolescentes que desempenham o trabalho doméstico também ficam expostas a maus-tratos, à violência físico-emocional e à violência sexual" (BERNARDINO-COSTA, 2011, p. 141-142).

Em segundo lugar, o aumento da idade de prestadoras de serviços domésticos é importante porque essas mulheres mais velhas, por um lado, contam com uma rede maior de colegas e de possíveis empregadoras que tornam trabalhadoras menos dependente dos empregos que classifique como ruins. Por outro, muitas vezes elas já têm filhos e filhas mais 
velhos que trabalham, trazendo implicações para a renda familiar que passa a depender menos dessas mulheres, o que reduz substancialmente a condição de vulnerabilidade e permite que se desempreguem temporariamente até que consigam encontrar famílias que classifique como melhores para trabalhar.

\subsection{MigRaÇão: LIBERTAÇÃ̃o OU PRISÃO?}

Além da migração familiar (que ocorreu nos casos de Cleide, Flávia, Cecília e Celina), prestadoras de serviços domésticos remunerados podem migrar sozinhas. Para isso, muitas vezes acionam redes de contados, seja com possíveis empregadores e empregadoras (Érica, Antônia), seja com parentes que moram em outras localidades (Zélia, Ângela), para ter alguém que as receba na cidade de destino. Um segundo fator que pode pesar nas suas ponderações é viabilidade de migrar baseada na proximidade da cidade onde estão outros parentes próximos (Antônia).

Migrar com a família ou sozinhas trará diferenças no vínculo que terão como trabalhadoras domésticas - externas ou residentes. Por sua vez, tais vínculos trarão consequências para a vida pessoal e para o relacionamento das trabalhadoras entrevistadas com a própria família. A migração entendida dentro de padrões em que associa o rompimento, o distanciamento ou o alargamento de laços constituídos à mudança de localidade muitas vezes significa que essas trabalhadoras se tornarão residentes nas casas em que vão trabalhar (BRITES, 2014, p. 140).

O passar dos anos tem feito o número de trabalhadoras domésticas residentes diminuir mais e mais, como tem diminuído também, num ritmo muito menor, o percentual de trabalhadoras migrantes (que moram fora da cidade de nascimento). Motta (1992) registra o momento histórico em que trabalhadoras domésticas residentes, categoria "ainda majoritária", "começa, lenta, mas inexoravelmente, a rarear" (p. 7), tendendo a se transformar em mais uma dentre as duas outras modalidades básicas de empregada doméstica: a mensalista externa e a diarista. Na Capital Federal, em 2001, trabalhadoras residentes representaram quase 1/5 da mão dessa ocupação; noutros Estados já foi próximo de 1/4 dela, embora a média nacional nessa época fosse de 6,97\%. Hoje, no Distrito Federal, esse percentual é de 3,41\%, um dos maiores índices dentre todos os Estados. A média nacional é de 1,24\%.

As entrevistadas que migraram com a família - Celina, Cleide, Cecília e Flávia estabeleceram-se nos próprios lares. As entrevistadas que migraram sozinhas - Zélia, Érica 
e Antônia e Ângela - se tornaram trabalhadoras domésticas residentes. Ângela e Antônia iam embora para a residência de amigas ou irmãs no final de semana. Érica e Zélia permaneciam inclusive nos finais de semana na residência onde trabalhavam.

Ser residente, tem importância capital no relacionamento de Antônia, de Ângela e de Érica com as próprias famílias, em outras unidades da federação. Como as três não podiam cuidar dos próprios filhos e trabalhar, eles foram deixados com os avós. Érica, embora inicialmente tivesse planos de ficar com o filho, acaba se dando conta da dificuldade que teria em conciliar o trabalho em casa de família morando como residente com cuidado do filho, especialmente porque a patroa também tinha um filho da mesma idade do seu. "Até quando o Bruno [seu filho] começou a amamentar eu dava conta de cuidar, porque amamentava, dava a comidinha dele, colocava ele no berço. Mas depois que ele começou a andar - os dois bebês começaram a andar - aí já ficou mais complicado".

Érica, que fugiu do lar, acabou por devolver à mãe, separada do marido, o próprio filho que se tornou o braço direito dela. Continuamente enviava a família uma quantia em dinheiro para ajudar nos cuidados necessários. Enviar ajuda em espécie não é a regra. Muitas vezes, como conta Ângela, se enviava o próprio produto, como caixa de leite, de ônibus.

O caso de Érica abre uma fresta para visualizar circunstâncias específicas e variadas que levaram as entrevistadas a migrarem. Além de Celina, Cecília, Cleide e Flávia mudaramse em companhia dos maridos e, no caso de Flávia, em companhia dos pais (ela é filha de Celina), a migração pode ser motivada pela fuga de contextos opressivos. Érica mudou-se para Brasília fugindo da mãe por estar grávida. Antônia e Ângela, migraram em busca de recomeçar a vida depois de se separarem dos maridos, desnecessário dizer que as três, como também Zélia buscavam melhores oportunidades haja vista que suas família dependiam delas.

\footnotetext{
Com relação às motivações para a migração, um outro conjunto de fatores de ordem não econômica parece ter impacto na seletividade da migração e é mencionado mais por mulheres do que por homens. Podem ser citados como fatores não econômicos: a transgressão dos limites sexuais impostos pela sociedade, os problemas conjugais e a violência física, a impossibilidade de divórcio, os casamentos infelizes e desfeitos, a discriminação contra grupos femininos específicos e a ausência de oportunidades para as mulheres. Conforme Morokvasic (1984) esses estudos apontaram para o fato de que as mulheres migram não apenas por razões econômicas, mas também por rompimento com sociedades discriminatórias, nas quais estariam em posição subordinada (ASSIS, 2007, p. 751).
} 
Para Érica, separar-se do filho foi um momento de grande desamparo. Nesse momento, a família que a empregava teve papel fundamental, ajudando, pagando passagem para que ela pudesse deixar a criança com sua mãe e fazendo o enxoval para o bebê. Não cabe aqui, julgar essa experiência de Érica de um ponto de vista externo como se ela não tivesse capacidade cognitiva de reconhecer as linhas de força às quais ela estava submetida. Para ela, não voltar para a casa da sua mãe, mesmo ao custo de se separar do filho e de assumir uma rotina de trabalho intensa significou a autorealização de se perceber senhora de si. Entre assumir uma rotina de trabalho que a colocasse inteiramente à disposição de outra família e voltar para uma cidade pequena para viver com a família, onde voltaria a estar submetida aos irmãos e à mãe, Érica preferiu a primeira alternativa. O que a aguardaria se voltasse, não se sabe. Mas se alguma coisa na sua pequena cidade de origem a oprimia, sendo mulher e mãe solteira, o mesmo não aconteceria para o seu filho homem, por isso ela o levou de volta sabendo que lá, diferente dela, ele seria mais bem cuidado.

Vieira (2014), na pesquisa que faz com babás, entrevista Sandra. Ao ficar grávida e não tendo como fazer pré-natal pela grande quantidade de serviço que tinha, Sandra deixou o trabalho e foi para sua cidade de origem no Maranhão. Lá, depara-se com a realidade patriarcal da localidade e é vista como uma nódoa na honra da família o que a leva a reformular sua decisão e voltar a Brasília, mesmo sabendo que não seria aceita pela antiga patroa por estar grávida (p. 44). Embora o relato de Érica deixe claro a boa relação que ela tinha com a empregadora e como esta se tornou, indiscutivelmente, uma das razões para não voltar à casa de sua mãe e irmãos, Sandra, entrevistada por Vieira, permite perceber algumas dimensões opressivas que incidem sobre mulheres de condição social muito próximas àquela vivida por Érica, até mesmo em relação aos valores regionais.

Esses arranjos e motivações para migrar, no caso das entrevistadas, se mostram articulados a outra característica dessa migração que distingue dinâmicas da migração masculina e da feminina. Enquanto Simão fala que "era um ziguezague que a gente fazia na vida que só Deus e nós encontrava o nosso caminho de volta"; nos casos de Zélia, Ângela, Antônia e Érica a migração dependeu de laços pré-estabelecidos. Todas se mudaram para Brasília com trabalho arrumado ou com alguém que as pudesse receber na cidade, destacando-se as redes de relações que possibilitam a migração feminina e que são menos presentes no caso da migração masculina, como permite perceber o ziguezague de Simão entre outros estudos (cf. ASSIS, 2007). Esse rompimento com contextos opressivos ou que visem subordiná-las 
possibilitado pelas redes de relações constituídas em lugares distantes acarreta outra característica. É interessante notar, que, no caso das entrevistadas, ao passo que a migração de mulheres acompanhadas dos maridos e filhos atribui um certo qualificativo de completude do núcleo familiar, no caso das que migram sozinhas isso não acontece. Ângela, Antônia e Érica tinham que cuidar do sustento de filhos e filha distantes, Zélia ainda ajuda parentes da sua cidade de origem, permanecendo, nesses casos em que migraram sozinhas, uma costura entre localidades distantes, localidades que ofereciam perspectivas absolutamente distintas às entrevistadas.

Assim, vários fatores que influenciam as correntes migracionais de mulheres do trabalho doméstico remunerado: migrar sozinha ou com a família; ter alguém que receba a migrante no lugar de destino; a proximidade de uma cidade onde se possa procurar por melhores condições ainda que, do ponto de vista econômico, não sejam tão boas quanto a de uma mais distante e a própria noção de migração presente aqui. Tudo isso torna a análise de fatores econômicos pouco precisa, embora cerca de $40 \%$ dessas correntes migracionais de trabalhadoras apontem para as regiões de destino em que são melhor remuneradas em território nacional (São Paulo, Rio de Janeiro e Rio Grande do Sul), independentemente de o trabalho doméstico ser razão principal ou colateral para mulheres que adensam esses fluxos.

\subsection{Trabalho AFETIVO E AMbigUIDADE AFETIVA}

Todas as trabalhadoras citadas tinham bons relacionamentos com os patrões. Antônia diz que embora todos a tenham tratado bem, "graças a Deus", o segundo emprego foi o que mais gostou como mensalista.

\footnotetext{
Gostava deles por causa do modo de eles me tratar. Não é por dar as coisas. Porque às vezes dizem que uma pessoa é boa de te dar as coisas. Eu gostava deles porque eles me serviam na minha necessidade. Então, tudo que eu precisava, eles não me davam, mas arrumavam para mim. Tudo que eu falava para eles, estavam prontos a me servir. [Quando] eu precisava de um adiantamento de um dinheiro, [de] comprar alguma coisa para mim, [eles] me ajudavam. Nessa época eu não tinha meus filhos aqui. Eu pedia ajuda para os meus irmãos. Nessa época, como eu ganhava pouco, aí ela me arrumava e eu vendia cerveja na rodoviária para completar o meu... E ela ajudava, ela comprava para eu vender. Mas dessas casas que eu trabalhei todos foram pessoas muito boas. Me tratavam bem, não me discriminavam. Porque você trabalha para as pessoas e as pessoas te discriminam.
}

Também Érica tinha boa convivência com as famílias com quem trabalhou. Da sua primeira patroa diz que ela a ajudou de todas as maneiras imagináveis. Da segunda fala do 
intenso relacionamento com as filhas da patroa. Razão porque sentiu grande tristeza quando teve que deixar o trabalho.

Com a Dolores, tomava conta das menininhas dela. Só que a gente se afeiçoa muito e o dia de amanhã você não pode contar. Você não sabe. Hoje você tá aqui, amanhã você tá acola e a gente quando vai cuidar de criança, principalmente o filho dos outros, você acaba sofrendo muito. Principalmente quando você tem que sair, você tem que se ausentar, e você tem que fazer uma escolha, e você acaba sofrendo. Sofre você e sofre a criança. Mas um dos trabalhos melhores que eu tive foi ter cuidado daquelas duas crianças (...). Quando eu saí na época da casa da Dolores parecia que tava saindo um pedaço de mim porque eu amava a Louise demais, demais, demais. Quando eu saí da casa da mãe dela, a menina sofreu tanto e eu também. Ela pediu para eu retornar. Eu ainda tentei mais uma vez, mas aí eu falei 'não, não dou conta'. Então, tanto sofreu a menina, como eu sofri muito. Porque a gente se afeiçoa. Às vezes o chefe pode não se afeiçoar a você, mas você acaba criando um vínculo. Você passa três, quatro anos, não é dizer que a pessoa não se afeiçoa. Claro que sim! Você tá todos os dias com aquela pessoa ali, todos os dias você tá vendo ele, ou, então, uma vez por semana, mas você tá vendo. Você tá lidando diretamente com ele.

Zélia e Flávia também nutriram bons relacionamentos, ambas têm contato com as patroas até hoje. Flávia, inclusive, é específica em indicar a única ex-patroa com quem não tem contato e porque não o tem: ela se mudou. Já Zélia contou que naqueles dias próximos da entrevista tinha ido ver o filho da ex-patroa no colégio.

Desse modo,

adoptando este punto de vista, la afección - es decir, la expresión y el intercambio de afectos - modela el tejido social del trabajo doméstico. Los afectos no sólo se perciben como emociones o sentimientos sino también como intensidades, sensaciones y reacciones corporales que perturban las relaciones de poder, aunque también las amplían y las reafirman. Si bien la teoría feminista ha resaltado el carácter emocional del trabajo doméstico, hablar de afectos pretende, más que reconocer la acción cognitiva del cuidado, entender cómo nuestras relaciones cotidianas son forjadas por afectos intuitivos, aplazados y desplazados, que a veces escapan de la dicha de la voluntad subjetiva. Es en relación con esto que propongo considerar el trabajo doméstico como trabajo afectivo. El trabajo afectivo está correlacionado así con los pulsos vitales de la vida y, por consiguiente, tiene una dimensión biopolítica. Es un tipo de trabajo que no puede ser medido cuantitativamente. Lo que produce el trabajo afectivo, por tanto, es intangible, y no siempre es material, ya que lo que produce está ligado a los sentimientos, las emociones y las energías. Adoptar una lectura tal del trabajo afectivo implica centrarse en la expresión intuitiva y no censurada de nuestros impulsos vitales en relación con los otros y con nuestro propio entorno. Inmerso en las energías del ámbito privado de los hogares, el trabajo doméstico no es sólo un receptor de afectos sino también un mediador y organizador de los mismos. Los afectos producidos se originan tanto en el interior como en el exterior, ya que no son sólo el resultado de las energías de los miembros del hogar sino también de la relación de cada uno de ellos con el hogar, y de cada hogar en particular con la sociedad en su conjunto (GUTIÉRREZ-RODRÍGUEZ, 2013, 131-132). 
A noção de trabalho afetivo de Gutiérrez-Rodríguez se assenta em dois eixos, o desmonte do estado de bem-estar social nos países europeus, onde empreende sua pesquisa, e a heteronormatividade vigente no ambiente doméstico. A transferência de responsabilidades que antes também faziam parte das atribuições do Estado para o interior da família e a fuga de tensões que poderiam advir ao se tentar implantar a divisão do trabalho doméstico de forma equitativa entre os gêneros fazem com que o esse serviço tenha uma conotação que vá além da simples execução de tarefas domésticas: o trabalho doméstico é também o trabalho de produção de bem-estar pessoal e interfere na convivência entre os indivíduos, especialmente pelo equilíbrio de poder, ainda que relativo, entre gêneros ${ }^{49}$. O sentido de "afetivo" está relacionado a isso e através das afecções produzidas é que se forjam as relações entre trabalhadoras domésticas e empregadoras.

Lo que modela estos encuentros es la transmisión de afectos, es decir, la afección. (...) la afección realza la dimensión energética del ser, el cual se siente movilizado por todo aquello que lo impulsa emocionalmente. Así, los afectos "adquieren relevancia cuando se proyectan hacia afuera, cuando uno se libera de ellos" (Brennan, 2004,6); por ejemplo, uno se puede sentir vigorizado por afectos como el goce y el amor (GUTIÉRREZ-RODRÍGUEZ, 2013, p.130).

Assim, as expressões involuntárias de contentamento, as afecções, manifestas por exemplo pelo empregador ou empregadora ao ver o trabalho bem feito, interferem "biopoliticamente" no cuidado dedicado à execução da tarefa uma vez que tais manifestações tocam emocionalmente a trabalhadora provocando-lhe. Isso tudo pode acontecer também ao inverso. O ponto a ser destacado na abordagem de Gutiérrez-Rodríguez é que o trabalho doméstico, considerando o trabalho afetivo que envolve, não é colocado contra um pano de fundo que prescreve relações impessoais como ideais ao ambiente de trabalho, seja por entender que as prescrições estão relacionadas à consciência de classe e a organização enquanto categoria trabalhadora, seja por entender que a pessoalidade e afetividade presentes no trabalho doméstico são a razão de ser de seu não reconhecimento enquanto trabalho. Nessa abordagem de Gutiérrez-Rodríguez retira o pano de fundo contra o qual o trabalho doméstico

\footnotetext{
${ }^{49}$ Nessa medida são instrutivas as leituras de Ávila (2012) e Sorj (2013). No primeiro caso, pela autora apontar que mesmo em face da transferência do trabalho doméstico a outras mulheres, o lugar feminino da dona da casa se reproduz no gerenciamento da trabalhadora contratada. No segundo, pela autora trazer a diferença das horas dedicadas ao trabalho doméstico por mulheres de diferentes classes sociais, portanto, que tem e que não tem trabalhadoras domésticas.
} 
adquire características idiossincráticas ${ }^{50}$ e a afetividade, não apenas do ponto de vista das afecções, mas também do ponto de vista das relações pessoais passa a fazer parte da produção específica que tem lugar no contexto doméstico.

Mas como entender, a partir dessa noção de afetividade as mudanças que se processam no interior dos lares em que trabalhadoras domésticas prestam seus serviços? As narrativas do porquê deixaram o primeiro trabalho são por vezes obscuras. Antônia, Zélia, Flávia deixaram o primeiro emprego que tiveram depois de poucos meses. Flávia, que ficou no primeiro emprego por oito meses, revela que teve uma briga com a babá, que deixava parte das próprias atribuições para ela. Antônia e Zélia não revelam a razão. Se limitam a dizer "não deu certo". Muitas vezes a trabalhadora que não encontre condições que julgue adequadas no serviço, pelo salário ser baixo, por promessas não cumpridas, por sobrecarga de tarefas ou porque se exige que faça atribuições que julga não serem suas acabam ficando no trabalho apenas o tempo estritamente necessário até arrumarem outro.

Muito diferente é a razão que as fizeram sair do último emprego como mensalista. Percebem que estão entrando em uma lógica diferente, como revela Cleide que tem medo de trabalhar apenas como diarista e ficar sem serviço. Ou como se pode perceber na fala de Érica que aprendeu a ser diarista ajudando a colega de trabalho e temia, no primeiro "teste" com diária, não conseguir o emprego.

Flávia e Cecília se afastaram dos empregos que tinham para ter e cuidar dos seus filhos. Quando voltaram foi na condição de diaristas. No caso de Flávia, embora considere que voltou trabalhando para a OAB (Ordem dos Advogados do Brasil), de fato fazia algumas diárias antes disso. Como as diárias não demandavam todos os dias da semana, conseguia conciliar com o cuidado da filha pequena. Algo parecido aconteceu com Cecília. Ela considera que voltou a trabalhar quando o filho tinha sete anos. Hoje ele tem treze. Sua cliente mais antiga tem dez anos. Desse modo fica claro que "voltar" ao trabalho está relacionado a frequência com que se ausenta de casa durante a semana. Portando, ela começou a fazer diárias quando ele tinha por volta de 3 anos. Fazia-as esporadicamente para poder cuidar do filho até efetivamente "voltar" a trabalhar.

\footnotetext{
${ }^{50}$ Brites (2000) fez o mesmo ao apontar que "relacionamentos clientelistas com os patrões são, de fato, táticas que lhes possibilitam tirar o melhor proveito possível de uma situação altamente desfavorável (p. 66)". A abordagem de Brites é absolutamente cabível em vários casos citados nessa dissertação. Érica fala da sua patroa que a ajudou de todos os modos possíveis. Antônia fala da patroa que a ajudava comprando cerveja para que ela pudesse revender, de patrões que compram eletrodomésticos e vão descontando aos poucos no seu pagamento... Mas isso nem sempre acontece.
} 
Dentre as que trabalhavam em casa de família como residentes, Zélia saiu do último trabalho porque os patrões arrumaram um emprego para ela em uma empresa terceirizada. Desde então, ela começou a fazer diárias esporadicamente. Quando foi demitida do emprego, foi que adotou as diárias como fonte de renda primária. Já Érica se demitiu do último emprego que teve como mensalista a contragosto. O patrão "usava droga" e às vezes ficava violento. No caso de Ângela, ela revela que como não era registrada, não tinha nada a perder, então, pediu demissão e começou a trabalhar como diarista. Por último, Antônia revela que saiu por que "vai indo, cansa!" de ver as mesmas pessoas todo dia.

“Vai indo, cansa!’? Mas Antônia não os considerava sua família? A resposta de Antônia traz uma dimensão presente na fala de outras entrevistadas: a do cansaço de ver os patrões, apesar do sentimento de gratidão. Esse ponto de vista não é exclusivo dela. Cleide e Érica compartilham dele. Todas têm em comum o fato de terem trabalhado em ambos os seguimentos do trabalho doméstico. Esse cansaço do qual falam se reporta à ambiguidade afetiva vivida no ambiente doméstico.

Não é difícil entender a discrepância entre a afetividade que Antônia sente em relação a seus empregadores, da qual fala longa e espontaneamente das boas experiências que teve com eles, e o sentimento de cansaço. Como disse, quando trabalhava e morava na mesma casa, tinha que ficar disponível o tempo todo, do amanhecer ao anoitecer. Mas morar na casa do patrão não significa apenas a disponibilidade integral, significa também a impossibilidade de experiências que se ligam ao espaço da residência e do que ele permite. Morar na casa do patrão não permite receber amigos. Mais que isso, essas trabalhadoras sendo na quase totalidade migrantes não podem sequer receber familiares distantes num fim de semana. Em outras palavras, a experiência da família que se realiza fragmentariamente amplifica a intensidade do trabalho. Assim, a ambiguidade afetiva que está relacionada a figura ambígua da prestadora de serviço, ora como empregada, ora como pessoa da família, diz respeito também às incompletudes vividas por trabalhadoras nesses dois aspectos da vida.

A fala de Érica, a seguir, mostra faces do trabalho afetivo realizado no ambiente doméstico na medida em que ele não consiste apenas em criar um ambiente aprazível, mas também envolve uma "ambiguidade afetiva" que são as trocas afetivas realizadas entre empregadores - geralmente a mulher e as crianças - e a prestadora dos serviços domésticos (BRITES, 2007). 
Érica começa dizendo que supunha que não houvesse bons patrões. Conhece Lourdes e essa experiência de trabalho muda profundamente o seu modo de pensar pela patroa terlhe ajudado de todas as formas que se possa imaginar, diz. Quando veio a trabalhar para a família seguinte, tinha se afeiçoado a menina de quem cuidava na casa da Dolores. Não tinha dado certo o trabalho uma vez, mas pelo sofrimento da separação tentou outras vezes, também sem sucesso. Ela arremata dizendo que no trabalho doméstico "o valor praticamente não existe. Se tiver uma ou duas que acaba te valorizando, ótimo. Mas muitas você trabalha a vida inteira e ela acaba não te enxergando. E a afeição. Você se afeiçoa muito a essas pessoas. Eu me afeiçoei a todos eles”. Assim, os sentimentos de valorização e desvalorização, estima e invisibilidade, medo e segurança estão constantemente sendo produzidos, revolvidos, revisitados e transformados a partir do quadro ambíguo em que a trabalhadora está inserida.

Noutro ponto Érica fala de casos de assédio sofridos e de como isso a obrigou a largar o trabalho, embora gostasse da patroa. O quadro definidor da situação que Érica acionou não foi pautado pela violência do ato, mas pela sua resistência, que tributa a suas crenças religiosas. Em vez de estabelecer o assédio como matriz que enquadra a situação, foi a relação com a patroa que definiu a situação. Assim, em vez de emergirem sentimentos de culpa ou vergonha (para citar aqueles muitas vezes relatado por mulheres que passam por isso), Érica sente tristeza por deixar a patroa que lhe estendera a mão, bem como gratidão a Deus por não ter incorrido em atitude que possa ser interpretada como uma deslealdade. A resistência não diz respeito unicamente à manifestação de repúdio ao assédio, mas também ao fato de não ter decorrido outros tipos de violência, que embora não consentidos, provocam sentimentos de culpa, vergonha e auto responsabilização.

O relato de Cleide é paradigmático ao demonstrar que a ligação entre trabalho afetivo e ambiguidade afetiva, que contrapõe o sentimento de ser da família ao cansaço, se estende também para o trabalho mensal externo:

Eu já tive outras oportunidades de trabalhar noutro serviço. Só que eu penso muito na pessoa que eu tô trabalhando. Na época que surgiu o serviço para mim, e era nas férias, veio de uma rede de cosméticos para ser vendedora. Só que eu pensei no patrão: 'tem suas crianças, quando eles voltarem como vão arrumar outra pessoa assim, de imediato'. Mas eu me arrependo de não ter pego porque, por melhor que seja o patrão, nunca eles vão pensar desse jeito, deixar de fazer alguma coisa por uma empregada. Jamais. Eu deixei. Agora, tenho vontade, mas para mim ir atrás de outro serviço eu preciso de um mês de - como é que a gente fala? - aviso prévio. 
A preocupação de Cleide está intimamente relacionada a experiências díspares vivenciadas por ela. $\mathrm{O}$ trabalho afetivo abre espaço para a ambiguidade que experimenta no ambiente de trabalho por entender que seus empregadores não são recíprocos nos sentimentos que manifestam em relação a ela. Por mais que Cleide reconheça que essa manifestação equivalente não seria nunca manifestada pelos empregadores, sua manifestação de preocupação não é gratuita, requer algum tipo contrapartida. O sentimento de retribuição equivalente que não vem na mesma proporção leva ao cansaço.

Essa falta reciprocidade não é algo que Cleide apenas cogita; baseia-se numa experiência bem real: a de que a patroa não dá satisfação quando volta tarde do serviço, comprometendo planos que Cleide por ventura possa ter feito por ter de ficar tomando conta do filho da patroa. Fica latente, embora Cleide não o diga com todas as palavras, que ficar tomando conta da criança até que a mãe chegue não se trata de uma imposição dos empregadores, ela espera a mãe chegar por se preocupar com a criança, no entanto, a empregadora não se preocupar em dizer quando volta do trabalho a fim de que Cleide possa fazer seus planos pessoais.

Assim, se trabalho doméstico como trabalho afetivo trata-se, do ponto de vista da trabalhadora, de manifestações que a convocam ao se perceber valorizada ou desvalorizada; a ambiguidade afetiva diz respeito a momentos críticos da relação entre empregadores e trabalhadora que informam ou levam a sopesar o sentimento de desvalorização. A literatura trata essa ambiguidade simplesmente como resultado da posição da trabalhadora situada entre a esfera pública do direito e a privada da reciprocidade. Nas entrevistas feitas foi possível perceber algo mais: quando tudo vai bem não se tem indícios para se chegar a essa ambuiguidade, mas quando ela vem a tona já é para dar conta de que algo está errado. Nos casos citados acima, destaca-se a sobrecarga e a disponibilidade integral ao trabalho, o assédio e a violência e, no caso de Cleide, a falta de reciprocidade.

A mudança do trabalho mensal está intimamente relacionada a possibilidade de se trazer filhos e filhas para a Capital Federal e passar a morar com eles. Morando em residência de (outra) família, as entrevistadas tinham dificuldade de conciliar trabalho e o cuidado de filhos e filhas. Durin (2014, p. 269) aponta que "servicio doméstico y maternidad suelen ser incompatibles; ser madre implica el paso del trabajo de planta a la modalidad por horas, o bien, la separación física de los hijos". A autora, que escreve a partir de um contexto de migração transnacional, aponta que a divisão entre maternidade e criação, ao promover uma 
divisão entre maternidade intensiva e maternidade compartida ou compartilhada que recruta cadeias de cuidado, cria a maternidade à distância (termo mais adequado ao contexto desta pesquisa, mas que a autora chama preferencialmente de maternidade transnacional). Esta "supone nuevas formas de cuidado y educación de los hijos, que se distinguen claramente por etnia y clase. Se define en términos de circulación de afectos, cuidado y soporte financiero que trascienden las fronteras naciolales" (p. 272). A autora ainda acrescenta que tanto no contexto da família empregadora quando da família da trabalhadora maternidade e criação são operados por pessoas distintas (p. 292). Embora a autora trate de contextos transnacionais, esses conceitos iluminam questões presentes nas narrativas das entrevistadas, podendo citar paradigmaticamente a fala de Érica.

Entre a família da trabalhadora e a família empregadora existe uma disputa que se revela em dois momentos: no primeiro, quando a família das trabalhadoras as leva a assumir um grau de autonomia maior em relação à família empregadora, como nos casos de Cecília, Cleide e Celina que se mudaram com os maridos, filhos e filhas. No segundo momento, quanto vieram para trabalhar como domésticas internas, Antônia, Érica e Ângela só puderam reunir a família com filhos e filha ao transitar para a modalidade de trabalho em que não ficasse integralmente disponível à família que as empregava. Tal transição não leva a uma mudança imediata nesses laços familiares uma vez que requer adaptações de condições, fechamento de planos em curso; enfim, uma confluência de fatores mais ou menos numerosos que criam o momento propício para a reunião de mães, filhos e filhas. Esse momento propício pode até mesmo não chegar a acontecer. A oposição entre maridos-que-ficam-com-aesposa e filhos/filha-que-ficam-sem-a-mãe, revela uma dupla condição dessas trabalhadoras enquanto residentes que as colocam numa posição estruturalmente oposta à condição da patroa da casa: são reguladas pelo trabalho quanto a expectativas de serem mães e esposas o que as leva a ficarem disponíveis em tempo integral para as famílias que as emprega. Esse é um preço que pagam na busca que empreendem na busca de melhores condições para poderem cuidar de parentes distantes. 


\subsection{O TRABALHO DE DIARISTA: ESPECIALIZAÇÃO, ORGANIZAÇÃO DAS TARE- FAS E EMERGÊNCIAS}

O modo como o trabalho doméstico de diarista entra na vida das entrevistadas traz diferenças no que diz respeito à relação com os empregadores, à própria família, ao rendimento percebido e a adesão como contribuinte previdenciária. Relacionada a primeira, é significativo que noções evocadas para abordar essa nova vertente dos serviços domésticos seja "modernidade", "racionalidade", "impessoalidade" (FRAGA, 2010; HARRIS, 2007), noções que, embora nem sempre apareçam reunidas (aparecem esparsas em diferentes bibliografias), andam em paralelo, remetendo, de certo modo, a transição da solidariedade mecânica à orgânica; dos laços de afeto e reciprocidade à dependência mútua pautada na especialização da divisão do trabalho social. Nesse quadro, uma avaliação pretensamente racional do trabalho doméstico pautado no rendimento e em fatores como contribuição não permite perceber os problemas inerentes a eleição exclusiva desses critérios.

Isso posto, vejamos como as ponderações sobre a própria família, remuneração e direitos (cuja porta de entrada é a contribuição, quer através da carteira assinada, quer como autônoma), nesse cenário em que trabalhadoras não ficam mais a disposição dos empregadores, se cruzam com a forma como o trabalho doméstico de diarista se organiza nas trajetórias das entrevistadas. Duas questões paradigmáticas permitirão discutir isso, a especialização no trabalho de diarista e a afetividade.

Partindo da noção de especialização no trabalho da diarista, será possível perceber que esta diz menos respeito às tarefas realizadas do que a gestão do trabalho. A figura do patrão e da patroa são deslocados; muitas entrevistadas, inclusive, usam o termo "cliente". O processo de gestão baseado não mais em ficar disponível para o patrão, mas no serviço a ser realizado, abre espaço para que trabalhadoras, a depender de como gerenciam as tarefas que têm de realizar, conciliem vários trabalhos ou várias diárias conseguindo obter um rendimento bem superior ao que ganhavam como mensalistas.

No entanto, a partir de dados da PNAD, vê-se que, somando os ganhos derivados de todos os trabalhos, o rendimento de diaristas (nos termos originais da PNAD, mulheres que trabalham em mais de uma residência) não chega a ser $20 \%$ superior ao das mulheres que prestam serviços domésticos em uma única residência - as mensalistas. A partir das entrevistas se percebe que diaristas executam muito mais trabalho que mensalistas. Uma casa pode acumular todos os trabalhos de casa a serem feitos na semana inteira para que a diarista 
dê conta de tudo no único dia em que presta serviço naquela residência. Disso se percebe que: 1) há uma discrepância entre o rendimento que se ganha a mais e o quando se trabalha a mais nos casos em que os salários estão próximos da média; 2) no caso em que trabalhadoras conseguem ter um rendimento consideravelmente superior, muitas vezes isso se torna possível por um trabalho hercúleo que praticamente elimina a sua convivência com a família. Começando por Antônia, o modo como se refere ao trabalho doméstico, remete a noção de especialização:

Tem gente que vai só para passar [roupa]. Igual, eu só limpo, eu não faço outra coisa. Só limpo. Tem gente que paga para pessoa ir lá só para cozinhar. Faz a comida para semana toda. Tem uma pessoa que você contrata só para organizar suas coisas. Hoje em dia tem até esse tipo de serviço. Você me contrata e eu vou lá organizar os seus armários. Hoje em dia ninguém tem tempo. Tem pessoas que ganham a vida de fazer compra no mercado para os outros, para passear com cachorro. Você tem um cachorrinho, você não tem tempo de passear com ele, você tem que contratar alguém. Hoje em dia, tem para tudo. Eu vou lá e limpo a casa. Outra vai passar. Outra já vai para fazer a comida, outra vai para passear com o cachorro.

Ângela também só faz faxina. "Não misturo serviço", diz. Mas esse não é único padrão no trabalho de diarista. De fato, pode nem ser o mais frequente. Embora Antônia perceba o trabalho doméstico como um trabalho especializado e execute tarefas relacionadas exclusivamente à faxina, nem todas as entrevistadas tem experiências parecidas. Como mostra Celina:

Lá [no Plano Piloto] às vezes trabalhava três dias numa casa só, outras trabalhava dois dias numa casa só. Só sei que lá eu fazia comida, fazia tudo para eles. Lá eu cuidava de gente doente. Chegava lá, eles botavam eu para cuidar de gente doente, eu cuidava. Fazia de tudo e ganhando o mesmo salário de diarista. Eu era novata, eles aproveitavam de mim. Aproveitaram de mim foi muito (...). Já trabalhei em lugar que eles deixavam a pia da semana sem lavar nem uma vasilha. Sempre eles gostavam de acumular. O único lugar que não acumula as coisas é para essa que eu trabalho agora.

Flávia também é responsável por arrumar absolutamente tudo nos apartamentos em que trabalha.

Os meus são rapazes e muitos chegam aqui com 17 anos e não sabiam fazer nada e continuam sem saber fazer nada porque tem alguém que vai lá uma vez por semana para organizar. Então, eles são totalmente dependentes de uma pessoa que vá lá uma vez por semana. Até para lavar um copo, que vai acumulando na pia. Aí você chega lá, tá tudo sujo. Às vezes eu lavo, passo, faço comida, faço comida para semana, congela e deixa. Porque é estudante, né, não tem tempo. Tem que fazer a comida além da limpeza, às vezes a roupa tem que lavar na mão. Faz isso em meio período. Tem que ser rápido. Tem que ter uma organização boa. (...) Se eu não for algum dia por motivo de doença tem que arrumar uma pessoa para ir 
no seu lugar. Eles já falam: 'se você não puder vir, me indica alguém', porque não pode ficar só. Porque as mães têm contato comigo, então, eu tô aí cuidando dos filhos delas e quando eu não posso ir eu tenho que avisar para ir outra pessoa cuidar deles.

Érica passou de uma condição em que fazia de tudo mesmo sendo diarista para uma em que passou a prestar serviço mais especializado:

O trabalho da diarista, ele acaba adoecendo você, ele adoece você, ele tira muito das tuas forças. Quando eu vi que eu não tava dando conta falei "vou fazer um curso que eu posso aprimorar". Resolvi fazer um curso no SESC, porque eu poderia chegar a trabalhar num hotel. Achava bonito, achava chique. Aí eu comecei a entender o mundo da diarista. O trabalho de uma diarista é ou passa a roupa, ou cuida da casa. Isso eu aprendi. Eu fiz o curso, a moça que ensinava disse "você precisa ter coragem [para dizer para seus clientes que o trabalho de diarista não inclui fazer tudo], se você não tiver coragem você não vai sair de onde você tá, você precisa ter coragem para conversar com todos eles. Vai ser natural alguém dizer para você "não, então para mim não dá mais"". Mas se você trabalhar bem, você não precisa ter esse medo, porque quando você conhece o seu trabalho você não tem medo de perder um [cliente] e ter que encarar o mercado de trabalho. Eu perdi muita coisa, mas aquilo que perdi em seguida ganhei de novo. E aí foi onde eu comecei a mudar minha vida e eu descansei um pouco mais. Antes, tinha dia que eu chegava em casa, que eu ia tomar banho duas horas da manhã, que eu chegava tão cansada que só jogava a bolsa do lado deitava e dormia. Duas horas da manhã eu acordava e ia tomar um banho de tão cansada que eu ficava. Mas depois do curso, melhorei, tive atitude de conversar com todo mundo. Quem gostava e realmente respeitava o meu trabalho aceitou e a gente continuou, quem não gostava ficou sem, depois voltou atrás e eu já não tinha mais vaga. Detalhe: na minha vida como diarista, graças a Deus, nunca fiquei sem [trabalho]. Às vezes faltava espaço [na semana para atender quem tinha interesse]. Espaço esse que eu acabei preenchendo com os dias que eu devia ficar com minha família. Então, acabava sendo de segunda a segunda. Tem muitos que interpretam a diária mal. Eu já trabalhei em casa que a pessoa sujava louca a semana inteira, ele não recolhia lixo, ele não fazia nada, então quando você chegava no apartamento tava um caos. Você chegava, da porta da frente já sentia aquele odor desagradável. Mas diária não é isso. Ela não envolve você lavar a louça de uma pessoa que passou a semana todinha sujando a louça da casa para sobrecarregar. Diária é limpeza. Você vai dar um grau na casa, debaixo de tudo, lavar o banheiro, é isso. Faxina de uma cozinha já é individual. Eu não sabia o que que era uma diária. Aí eu vi que estava sendo explorada, que algumas coisas já estavam passando do limite. Você organizar casa é uma etapa. Você passar roupa é outra etapa. Você chegou na cozinha já é outra etapa. Agora, se você formou um conjunto, se você acha que dá conta de passar roupa, dar uma faxina numa cozinha e ainda lavar louça e fazer comida para aquele chefe aí você já vai fazer um acordo em conjunto com ele: "olha, eu vou fazer isso por tanto [por tal preço]". E você vê se de fato você dá conta daquele trabalho. No meu caso não. Quando eu fiz o curso que eu entendi isso, foi então que eu aprendi a separar. E para mim foi difícil eu chegar e conversar com o chefe ou a chefe. Mas eu tive coragem, cheguei e conversei.

Mesmo nos casos em que se adota a perspectiva do trabalho doméstico como trabalho especializado, isso muitas vezes não coincide com o vivido pela própria entrevistada. Embora identifique-se como quem faz limpeza, Zélia acrescenta, 
às vezes eu passo também (...), às vezes eu cozinho também (...). Tem uma casa que eu faço isso sempre, toda quinta feira eu cozinho, deixo a comidinha pronta. Faço a comida, deixo pronta, uma comidinha básica para deixar para pessoa e almoço também. Faço a comida e a limpeza. Em duas casas, além da limpeza também tem que passar, [em] uma [dessas casas] que eu comecei agora e tem outra casa que eu vou na sexta-feira de quinze em quinze dias, para um casal, toda vez que eu chego lá eu arrumo e passo (...). Como diarista você vai dar uma geral na casa. E, como mensalista, estando todos os dias ali, cada dia você faz uma coisa. Você estando frequentando todo dia aquela casa você não faz tudo de uma vez. Como diarista você tem que fazer e deixar tudo limpo para próxima vez que você for. A diarista tem que deixar tudo organizadinho, tudo limpo para, na próxima vez, você fazer a mesma coisa. E você estando, na casa da pessoa fixo, você tem que dormir, tem que ficar; e diária, não. Você faz a diária e vai embora.

As falas mostram que existe a tendência a narrar ou a perceber o trabalho doméstico de diarista como especializado, distanciando muitas vezes de como ele é praticado de fato. Monticelli (2013) ressalta que:

as formas de tarefas que as diaristas precisam fazer foram modificadas com o tempo. Durante o período de 1890-1930 eram contratadas para trabalhos específicos como a limpeza de um cômodo ou na lavagem das roupas, assim como apresentadas na obra de Matos (1994). Nunes (1993) também traz essa característica nos anos 90, no qual as diaristas trabalham com congelados, limpeza pesada, ajudante por um dia da trabalhadora doméstica mensalista. O que vemos hoje é a contratação de diaristas para realizar todas as tarefas domésticas, como lavar louça, banheiros, roupas, varrer, tirar o pó, passar. Tarefas que antes eram designadas às trabalhadoras mensalistas, formando assim novos tipos de contratações, em que todas as tarefas domésticas são designadas a uma pessoa que as realiza durante algumas horas de um dia (MONTICELLI, 2013, p. 27).

Então, como entender o pressuposto de realização de trabalho específico que ronda o trabalho doméstico na modalidade prestada diariamente? Zélia dá uma pista importante ao dizer que "você estando na casa da pessoa fixo você tem que dormir, tem que ficar; e diária, não. Você faz a diária e vai embora". A noção de trabalho específico, embora não signifique, a rigor, executar trabalho diferente do que faz uma mensalista, de fato, opera uma mudança significativa na medida em que por ser um contrato por empreita (baseado no serviço a ser executado, como diz Érica: “Olha, eu vou fazer isso por tanto [por tal valor]”) a trabalhadora não fica mais esperando as ordens ou os acontecimentos. Quando trabalhava como mensalista, Antônia ficava esperando o patrão chegar à noite para preparar-lhe um café ou lanche. Como diaristas, Flávia e Zélia fazem a comida e congelam para as pessoas para quem trabalham. O trabalho de diarista desloca a figura do patrão ou da patroa de quem se recebe ordens, tornando-a mais distante. Vez ou outra emerge na fala das entrevistadas o sintomático termo cliente como que a denunciar o deslocamento da figura do patrão e da patroa. Como diz Antônia: 
Hoje tá melhor. É melhor chegar e não ver ninguém. Não tem ninguém para me incomodar, nem eu incomodo ninguém (....). Chego lá, faço o meu serviço direitinho. Se eles têm uma reclamação, deixam escrito ou, então, me ligam e a gente não desgasta vendo um ao outro. Hoje em dia o pessoal é muito ocupado, não tem tempo. Então, querem alguém de confiança para fazer o serviço.

Não tendo um patrão de quem receber ordens, ou sendo esta uma figura mais distante do que tradicionalmente se concebia, a especialização se desdobra não sobre a tarefa, mas sobre a gestão do trabalho. Quando pergunto qual, entre os dois trabalhos que tem, é o seu preferido, o de diarista ou de faxineira em uma escola, Flávia diz:

\begin{abstract}
para falar a verdade, a diária. Não é nem a questão do dinheiro. É o jeito de trabalhar. Eu trabalho mais livre. Eu faço o meu trabalho mais livre, entendeu? É um tipo de trabalho assim, eu chego, vejo o que tem para fazer, eu vou e faço. Aqui [na escola] não, você está fazendo uma coisa, aí te tiram dali, te põem noutro canto e você nem faz uma coisa e nem outra. A desorganização, é isso que atrapalha, somente isso; que no meu trabalho eu me organizo. Que lá nas diárias eu chego e faço a minha organização, que eu tenho uma meta, que eu tenho uma meta a cumprir naquela casa. Aí eu chego lá, me organizo que eu vou fazer isso, isso e isso. Tal hora eu preciso ir embora. Então, eu tenho que fazer isso e isso e terminar que eu preciso ir embora, deixar tudo ok. E aqui eu não tenho essa organização, não posso fazer essa organização. Porque tem alguém por trás de mim que faz. Só que é uma organização meio desorganizada.
\end{abstract}

Assim, a possibilidade de gerir o trabalho permite que ele seja executado em menos tempo que o mensal, abrindo espaço para ganhos maiores, que podem ou não se realizar a contento. As perspectivas positivas sobre o trabalho doméstico de diarista se baseiam nessa possibilidade. Flávia e Zélia aproveitam essa oportunidade. Zélia e Flávia, trabalham um período como diaristas, Flávia de manhã e Zélia à tarde. Após terem deixado o trabalho doméstico mensal, passaram a fazer diárias e a conciliá-las com outras atividades. No caso de Zélia foi com o trabalho em uma academia a poucas quadras de sua casa. Flávia, que mora em Sobradinho concilia com o trabalho no colégio em outra região administrativa do Distrito Federal (ver anexo B). Todos os trabalhos de Flávia são no Plano Piloto. Ambas conciliam as diárias com trabalhos registrados como faxineiras; ambas trabalham mais horas e ganham menos por essa segunda jornada de trabalho.

Enquanto Zélia gosta do trabalho de diarista porque sempre tem o seu dinheirinho, Flávia aponta também a liberdade de se organizar. Ambas também são levadas a assumirem uma segunda jornada de trabalho por razões semelhantes: enquanto Zélia lembra principalmente a instabilidade do trabalho de diarista e o risco de ficar adoentada sem ter como trabalhar - nesse sentido, a carteira de trabalho assinada representa uma segurança de que terá 
como pagar suas contas; Flávia, que também demonstra preocupação com a situação imprevisível em que questões de saúde podem coloca-la, bem como limitações decorrentes do envelhecimento, lembra que trabalha para estudantes e menciona o fato de que quando chega as férias fica com pouco trabalho. Além disso, busca garantir sua "aposentadoria", mas não pelo INSS. Procura economizar o possível da renda extra para investir na construção de quitinetes para alugar no terreno que possui.

A busca de segurança emerge como um dos principais fatores pelas quais Zélia e Flavia buscam o trabalho registrado, especialmente porque através dele têm acesso ao auxílio-doença que valorizam pelo medo de se verem temporariamente debilitadas e com dificuldades de arcar com obrigações contraídas.

Ao falar sobre os seus dois empregos, Zélia diz:

Fico na academia porque lá tenho carteira assinada. O Fundo de garantia é mais seguro porque, às vezes naquele momento você não tá trabalhando e não consegue um trabalho. Acho importante por isso. Acho importante por causa disso, [do] seguro-desemprego, [e do] Fundo de Garantia. Porque você tá desempregada, mas você tem segurança de que vai receber aquele dinheiro. Você tem que comer, você tem que vestir, como eu, eu sustento minha família. Tenho que comer, tenho que me vestir, tenho que pagar meu aluguel. É seguro por causa disso. Ajuda a ficar mais tranquilo, mas é muito preocupante. Eu pago $\mathrm{R} \$ 800,00$ com despesa, condomínio, conta de luz vai uns $\mathrm{R} \$ 1.000,00$ por mês (...). Como a gente que é diarista, a pessoa que é diarista ela não tem carteira assinada, não tem nada. Porque se você adoecer o que é que você vai fazer? Você não tem Fundo de Garantia, não tem segurança, o que é que você vai comer, com que é que você vai pagar seu aluguel.

Flávia recoloca a preocupação com a estabilidade e com estar bem de saúde, razão que a leva a assumir um trabalho registrado:

A idade tá chegando e chega uma certa idade em que você não consegue mais trabalhar como você trabalhava. A idade tá chegando, aí vai ficando mais difícil. Aí você não dá conta de trabalhar, você não pode ir no médico porque você não tem direito de ir no médico, porque não paga previdência social. Então, vai ser amparado por quem? Se adoecer não tem como você ser amparado. Um erro: poderia pagar, mas a gente não paga. Quando é particular acaba não pagando. Aí eu comecei a pensar muito nisso: 'tenho que arrumar um trabalho fixo'. E [trabalhando como] diarista, hoje eu tenho [dinheiro]. Amanhã, os meninos entram de férias, viajam todos, eu fico sem nada. Pensei também nisso. Final de ano, viaja todo mundo. Aí fecham as casas, aí viajam, passam um mês, dois [meses] fora. Que eu trabalho para universitários, suas famílias são todas de fora de Brasília. Aí passam dois, três meses fora, aí eu fico sem trabalhar. Mesmo nas casas em que trabalho há quatorze anos isso acontece. São ex-universitários. Já se formaram e hoje têm seus empregos aqui, mas viajam porque as famílias moram fora. Chega férias, vai, passa um mês e eu fico um mês sem trabalhar nessa casa. Aí eu comecei a pensar na minha garantia de salário também. Como diarista [a gente] ganha mais, mas tem os prós e os contras, porque você não tem uma garantia. Você vai viajar e eu trabalho na sua casa, sou diarista, aí você viaja, o meu dia vai ficar livre, mas 
eu fico presa a você, porque você viaja, passa um mês, quando você voltar eu estou ali disponível esperando para trabalhar (...). Penso também em caso de doença, [para que,] se você adoecer você tem uma segurança. Porque se eu adoecer, como diarista, eu não tenho segurança nenhuma. Eu não tenho salário. Se eu adoecer eu vou depender de alguém para cuidar de mim com dinheiro da pessoa. Já até pensei em pagar contribuição, mas só pensa e não vai atrás.

Isso, no entanto, é só parte da história. Flávia e Zélia se tornaram diaristas depois de terem sido demitidas do último trabalho que tiveram registradas. Foi um período muito difícil, lembra Zélia. Ambas eram terceirizadas. Nessa medida, pela experiência adquirida, parecem carregar as marcas que as fazem reconhecer a sua posição flutuante no mercado de trabalho não-doméstico - contudo feminizado - na promoção de uma dupla segurança: a segurança do direito e a segurança do rendimento. No primeiro caso, pelo trabalho com carteira, no segundo, pela diária. Sabem que, trabalhando apenas registradas, caso percam o emprego, perdem toda a fonte de renda. Já, com as diárias, vão-se clientes e voltam clientes, mas dificilmente ficam sem trabalho nenhum durante a semana. Então, com as diárias sempre é possível dar um jeito. Com o trabalho registrado, não...

Em direção diferente das duas, Érica fala da perspectiva de alguém que tendo se realizado quanto possível financeiramente no trabalho doméstico decidiu deixá-lo:

\begin{abstract}
Mas é complicado de pagar contribuição porque você acaba fazendo tanto compromisso e o último compromisso que você quer ter é você pagar INSS. Eu só consegui pagar INSS como terceirizada. E se você for fazer uma pesquisa são poucas delas que contribuem. Quando você não paga o INSS, quando você não tem nenhum planejamento a sua expectativa de vida é só trabalho, trabalho, trabalho, trabalho. Agora, quando você..., hoje eu vejo a diferença, hoje eu ganho mais pouco, mas eu vejo uma qualidade de vida melhor. Hoje, se eu adoecer, eu não vou ter medo de chegar num médico e falar "olha, eu não tô me sentindo bem, não tô dando conta", de medo dele chegar e me dar um atestado. Eu não vou ter aquela preocupação de chegar e falar "olha, eu tô de atestado, minha família vai passar necessidade". Não, eu tenho uma garantia porque eu estou contribuindo exatamente para que eu venha a ter essa segurança. Então, para mim hoje existe uma diferença muito grande, foi um salto muito grande que foi dado, né? Apesar de que você ganha mais pouco, você tem uma segurança. Antes eu ganhava bem, mas eu não tinha segurança.
\end{abstract}

Desse modo a ausência de direitos não apenas levou entrevistadas a conciliar o trabalho de diarista com outras ocupações em que ganham menos, mas também levou, como aconteceu com Érica, a deixar as diárias e a migrar para outra ocupação com remuneração menor, mas que a faz se sentir mais segura. Cecília adensa o número de trabalhadoras que que está mudando a trajetória de sua vida em função de um trabalho registrado. Apesar de não deixar o trabalho de diarista, vai dispensar clientes para passar a trabalhar principalmente 
como mensalista pelas mesmas razões que Érica: ter maior segurança. Apesar de seu orçamento ser reduzido com a mudança, além das vantagens que pontua em passar a ter férias, $13^{\circ}$ salário, cita também a segurança do auxílio-doença, que reputa como um dos maiores benefícios pela segurança que proporciona de poder ficar doente sem que isso venha a prejudicar a família. Curiosamente, como contribuinte autônima Cecília também tem esse último direito, que, no entanto, é visto como incerto na condição de contribuinte autônoma.

Quando pergunto à Flávia se não seria melhor pagar contribuição e fazer outra diária a assumir uma segunda atividade de menor remuneração, ela se limita a dizer a mesma resposta que outras entrevistadas também deram: diarista não paga contribuição. É pelo registro em carteira que as entrevistadas procuram a segurança de ser uma trabalhadora regularizada. Avaliando a partir do ponto de vista legal, a diarista que paga contribuição previdenciária na condição de microempreendedora individual, possibilidade que passou a ter a partir de 2015 , não tem direito a salário-família, a auxílio-acidente, férias, $13^{\circ}$ salário e, se optar pela alíquota de 5\% de contribuição, também não terá direito à aposentadoria por tempo de contribuição (ela poderá completar futuramente a alíquota para se aposentar por tempo de serviço. Atualmente, a alíquota para que se possa pedir esse tipo de aposentadoria é de $21 \%$ ). Também, não tem qualquer direito a férias como contribuinte individual.

A segurança do registro concorre, na fala das entrevistadas com o "dinheiro" que ganham a mais ao mencionarem as razões para assumirem outro trabalho. Nesse sentido, avaliando a partir das tarefas realizadas, o trabalho das diaristas significa muito mais dispêndio de energia física para uma remuneração por dia de trabalho um pouco melhor do que a de mensalistas. Por um lado, a partir da PNAD 2014, a média de rendimento de diaristas é $\mathrm{R} \$ 760,99$ e de mensalistas é R \$ 648,82. Quando tabulado dados sobre os rendimentos de todos os trabalhos ${ }^{51}$, para diaristas e mensalistas as médias foram de $\mathrm{R} \$ 781,19$ e $\mathrm{R} \$ 657,71$, respectivamente. Isso significa que uma diarista que pague a contribuição como autônoma, teria um acréscimo líquido de $\mathrm{R} \$ 74,12$ no primeiro caso e de $\mathrm{R} \$ 84,42$, no segundo, descontado o valor da alíquota de $5 \%$. Some-se a isso o fato de que existe uma variação grande no que é entendido como trabalho de diarista, mas dado que uma parcela delas faz num dia a tarefa da semana inteira, há um número significativo de diaristas que em uma semana de

\footnotetext{
${ }^{51}$ Para se compreender bem isso, Érica, Flávia e Zélia que trabalham registradas para empresas e como diaristas têm dois trabalhos. Cleide trabalha e Cecília vai trabalhar como diarista e mensalista. Os dois contam como apenas um trabalho. Esses números são diferentes do que constam na tabela 7, p.83.
} 
trabalho realiza a tarefa que uma mensalista faria em aproximadamente um mês. Muitas, para driblar a insegurança e a instabilidade, trabalham o quanto podem "hoje" porque não sabem como será o futuro. Trabalhar o quanto pode, nos casos em que isso acontece, não significa necessariamente assumir outra colocação como diarista; pode ser até no mercado de trabalho não-doméstico, mas geralmente não se consegue atravessar a fronteira do trabalho de cuidar, como nos casos de Flávia e Zélia.

Quando se deixa de lado o questionamento sobre a possibilidade da acumulação de tanto trabalho, quando se ignora a quantidade de trabalho não remunerado que prestadoras de serviços doméstico têm nas suas casas, quando se ignora tudo isso "aproveitar" ou não tais possibilidades abertas pelo mercado de trabalho de diarista se torna apenas uma questão de tradicionalismo ${ }^{52}$. Do mesmo modo, quando se leva em conta tudo isso percebe-se que se dispor a tanto trabalho traz questões que levam em conta muitos elementos: saúde, preocupação com o futuro e a aposentadoria, bem-estar da família....

De forma geral, 97,27\% das trabalhadoras tem apenas um trabalho. Esses dados não dizem muito porque, independentemente do número de residências em que uma diarista preste serviço, será considerado apenas como um trabalho. Na tabela seguinte, pode-se ver a quantidade de horas trabalhadas por diaristas e mensalistas no serviço remunerado.

Tabela 9: PERCENTUAL DE DIARISTAS E MENSALISTAS DE ACORDO COM AS HORAS TRABALHADAS EM TODOS OS TRABALHOS DA SEMANA (EM \%) - BRASIL

\begin{tabular}{|l|r|r|}
\hline \multicolumn{1}{|c|}{ Horas trabalhadas } & diaristas & mensalistas \\
\hline Até 14 horas & 11,86 & 12 \\
\hline 15 a 39 horas & 50,6 & 31,38 \\
\hline 40 a 44 horas & 23,77 & 35,59 \\
\hline 45 a 48 horas & 6,69 & 11,8 \\
\hline 49 horas ou mais & 7,08 & 9,23 \\
\hline Total & 100 & 100 \\
\hline
\end{tabular}

Fonte: microdados PNAD 2014. Elaboração própria.

Esses dados, porém, desconsideram a intensidade do trabalho, como foi visto, e desconsidera o quanto trabalhadoras domésticas têm de trabalhar numa segunda jornada, não remunerada de trabalho doméstico.

\footnotetext{
${ }^{52}$ Para Weber o conceito refere-se à atitude de trabalhar o estritamente necessário para manter o mesmo padrão de vida. Nesse caso, a valorização da hora trabalhada, em vez de levar a trabalhar mais, leva a trabalhar menos para manter o mesmo padrão (cf. WEBER, 1991).
} 
Tabela 10: NÚMERO MÉDIO DE HORAS SEMANALMENTE DISPENSADAS POR TRABALHADORAS NO SERVIÇO DOMÉSTICO NÃO REMUNERADO - BRASIL

\begin{tabular}{|l|r|}
\hline \multicolumn{1}{|c|}{ Grupamentos Ocupacionais } & horas trabalhadas \\
\hline Dirigentes em geral & 16,74 \\
\hline Profissionais das ciências e das artes & 17,89 \\
\hline Técnicos de nível médio & 19,03 \\
\hline Trabalhadores de serviços administrativos & 17,37 \\
\hline Trabalhadores dos serviços & 22,11 \\
\hline Vendedores e prestadores de serviço do comércio & 21,18 \\
\hline Trabalhadores agrícolas & 28,06 \\
\hline Trabalhadores da produção de bens e serviços e de reparação e manutenção & 21,79 \\
\hline Membros das forças armadas e auxiliares & 17,26 \\
\hline Ocupações maldefinidas & 12,69 \\
\hline Trabalhadoras domésticas & 22,53 \\
\hline
\end{tabular}

Fonte: microdados PNAD 2014. Elaboração própria.

Além de ser um trabalho duro, as mulheres empregadas nos serviços domésticas formam o segundo grupo dentre todos os grupamentos ocupacionais a se ocuparem por mais tempo nos afazeres domésticos.

Entre diaristas e mensalistas, a média de tempo no trabalho doméstico é de 23,49 (23:29h aproximadamente) para diaristas e de 22,08 (22:05h aproximadamente) para mensalistas. Assim, embora seja demasiadamente dura a conciliação entre trabalho de diarista e outras fontes de renda, não é menos difícil os casos em que não há conciliação.

Em resumo, se o trabalho doméstico de diarista, em razão da forma como ele se organiza, possibilita ganhar mais, seja por hora, seja por dia; em relação ao esforço do trabalho o ganho se torna indiscutivelmente menor. De forma geral, porém, se veem limitadas em parte pela carga de trabalho pesada e pelo trabalho não remunerado que realiza também na própria casa. A dimensão dos direitos revela as inseguranças dessa modalidade de trabalho doméstico. Sem qualquer respaldo legal têm de trabalhar constantemente e, nesse caso, a possibilidade de ficarem doentes representa um grande perigo por não terem em quem se amparar, pelo risco que isso traz ao bem-estar da família e ao cumprimento de obrigações constituídas. As possibilidades de regularização do vínculo empregatício disponível às diaristas não são suficientes porque elas acabam usando o dinheiro em outras necessidades. Em face disso, a contribuição paga pelo empregador se mostra uma alternativa melhor tanto pelo baixo valor a ser pago a mais pelo demandante do serviço, quanto pela possibilidade de que possa se sair melhor no atendimento da burocracia exigida do que sua diarista.

Do ponto de vista do empregador, contratar os serviços de diaristas significa arcar com o valor de não mais do que uma diária (diferente do que emprega mensalmente que 
além do salário também paga encargos). Muitas vezes a contratação de uma diarista por alguns dias na semana não acarreta prejuízo do trabalho que seria feito se tivesse uma mensalista que trabalhasse todos os dias, principalmente pelo fato de que muitas vezes se acumula as tarefas de uma semana inteira para que a trabalhadora a realize num único dia. Desse modo, se Brasília apresenta uma média de rendimento de pouco mais que um salário mínimo para mensalistas, pode-se considerar que a faixa atualmente seja entre $R \$ 900,00$ e $R \$$ 1.000,00 (o salário mínimo é $\mathrm{R} \$ 880,00$, atualmente), que devem ser acrescidos de $20 \%$ de encargos, além do vale-transporte, do qual se pode descontar até $6 \%$ da trabalhadora. Lembrando que se pode descontar os encargos do INSS de uma única trabalhadora do imposto de renda ( $8 \%$ sobre o valor de não mais do que um salário pago). Muitas vezes, mesmo que a trabalhadora receba mais que um salário, é registrada como ganhando apenas o mínimo, um salário, para reduzir os encargos. Já, se contratar uma diarista, isso significa um gasto mensal de cerca de $\mathrm{R} \$ 600,00$ trabalhando um dia por semana ao maior custo da diária. Se esse empregador decida pagar a contribuição de sua diarista, isso representa um aumento de $\mathrm{R} \$ 30,00$ no custo do serviço.

\footnotetext{
Nenhuma das diaristas entrevistadas fazia o pagamento do seu próprio INSS, pois justificavam que não sabiam onde ir, por onde começar e a quantia que teriam que pagar lhes faria falta no final do mês. Esses direitos são suprimidos também por um aspecto da imediaticidade descrita pelas diaristas, os gastos com os filhos, com sua própria casa, com confortos, lazer e com as necessidades cotidianas, tais como luz, água, mercado se mostravam bem mais importantes para elas do que propriamente os direitos futuramente adquiridos pela contribuição previdenciária (MONTICELLI, p. 159).
}

De acordo com os números anteriormente vistos, trabalhadoras diaristas em geral ganham entre $17 \%$ e $19 \%$ a mais que as mensalistas; bem abaixo, portanto, das possiblidades abertas pela nova forma de contratação e bem abaixo também do que se poderia esperar a julgar pelo esforço despendido nessa ocupação. Foi possível encontrar trabalhadoras que conseguiam aferir bons rendimentos do trabalhando como diaristas, mas não se pode atentar para vantagens das possibilidades abertas por essa modalidade de trabalho doméstico colocando entre parênteses que para que tais possibilidades se realizem a contento é necessário um esforço quase sobre-humano, como o demonstram Érica e Flávia. Tão pouco se pode esquecer que dentre todos os grupamentos ocupacionais, o formado por trabalhadoras domésticas é um dos que tem maior jornada de trabalho não remunerado no próprio lar. Assim, se por um lado o grupo com o qual conversei diverge do quadro geral de diaristas pelo salário 
relativamente elevado, as outras instâncias acima apresentadas permitem reestabelecer o elo entre os casos particulares e os gerais.

Os direitos, garantidos pela contribuição previdenciária, no caso das entrevistadas, assumiram um papel importante na avaliação que faziam da segurança da própria manutenção e na manutenção das suas famílias. Mas não os procuravam por intermédio da contribuição autônoma. Mesmo conciliando as diárias com trabalhos em que ganhavam menos (Flávia e Zélia), deixando o trabalho de diarista (Érica) ou deixando a maior parte dos clientes atendidos nas diárias para assumir um posto como mensalistas (Cecília, que pagava contribuição autonomamente), o caminho escolhido para se tornarem trabalhadoras regularizadas foi pela carteira assinada.

\subsection{AFETIVIDADE NO TRABALHO DE DIARISTA}

Antes trouxe o pressuposto da especialização no trabalho doméstico de diarista e, a partir disso, abordei a questão do rendimento e da contribuição previdenciária. Agora passo ao pressuposto da impessoalidade que muitos apontam ser mais presente no trabalho da diarista. A importância disso deriva do fato de que em grande parte da literatura sobre trabalho doméstico a afetividade é vista como um elemento clientelista responsável pelo não cumprimento do legalmente prescrito, atentando contra a condição de trabalhadoras. Na literatura que desconstrói a noção de clientelismo, a afetividade é vista como prática política que visa a instrumentalização de relações pessoais para o enfrentamento de condições de vulnerabilidade e desigualdade sociais. Em relação as mulheres entrevistadas nesta pesquisa o quadro que se delineou foi diferente do esperado. No trabalho doméstico de diarista se verificaram relações de afetividade a partir três manifestações distintas.

Antônia quando aponta que relações de confiança construídas constitui um fator fundamental de satisfação nesse trabalho:

Não é por dar as coisas, porque às vezes dizem que uma pessoa é boa de te dar as coisas. Eu gostava deles porque eles me serviam na minha necessidade. Então tudo que eu precisava, eles não me davam, mas arrumavam para mim. Tudo que eu falava para eles, eles tavam prontos a me servir. Eu precisava de um adiantamento de um dinheiro, comprar alguma coisa para mim, me ajudavam. Se eu precisar de ajuda é só ligar que eles me ajudam. Você entende o tipo de ajuda, né? Eu estando doente [e] falar preciso disso, eles me ajudam. Se preocupam comigo. Já aconteceu e acontece quase direto. Se eu precisar de comprar uma coisa para casa eles tirarem no cartão para mim. Agora mesmo, fiz uma reforma na casa e tenho um patrão que tem loja de material. Ele me cedeu todos os materiais que eu precisava e a gente vai descontando. Fez uma diária hoje. Eu vou toda semana. Aí desconta metade. 
Às vezes precisa comprar alguma coisa: 'fulano, compra isso no seu cartão para mim”. A patroa vai e compra. Tem patrão que compra até 4, 5 mil no cartão. Já confia na gente. Esses dias mesmo queria comprar uma geladeira nova, uma televisão, você sabe que tudo é caro. Liguei para patroa a patroa comprou quase 5 mil no cartão dela. Então confia na gente, né? É uma forma de confiar. Tenho meus filhos, meu filho estudava, precisava de comprar alguma coisa, vou lá e corro: "O fulano, compra isso no seu cartão". É na hora. Às vezes eu nem vou na loja. Eles só ligam, falo o que eu quero, ainda compram e ainda vem deixar na minha porta. Então eu não sinto como uma.... Para mim eles são a minha família. Porque se eu preciso de médico me levam no hospital particular. Tem patrão que me leva para consultar em hospital particular. Então, eu considero eles como minha família. Todos eles. Eu tenho cliente que tem farmácia, preciso de remédio eles me trazem na porta. Às vezes não me cobram aquele remédio. Todos que eu trabalho, se eu ligar e precisar é na hora. É o ditado, uma mão lava a outra. Eu ajudo eles e eles me ajudam. Eu tenho uma neta. Negócio de vestuário essas coisas eu não compro. Eles dão tudo para minha neta. Para mim eles não..., não tenho o que dizer deles. Não sei se é pelo tempo que eu trabalho, a minha confiança. Eu tenho um lugar em que eles mexem com muito dinheiro. Eu fico lá, não mexo com nada deles. Eu acho que é isso também. Já tem aquela confiança. Já pensou você sair e deixar sua casa.... Tem lugar, igual a Raquel, viajou, roubaram a casa dela e quem foi lá e conferiu o que roubou foi eu. É pessoa que confia na gente.

A fala de Antônia aponta para práticas políticas (BRITES, 2000) que atravessam tanto o trabalho doméstico mensal quanto o de diarista, como o atestam Antônia e Érica que fala muito da ajuda recebida por sua antiga patroa que fez o enxoval de seu filho e a ajudou de todas as maneiras que se possa imaginar, como diz. No entanto, trabalho doméstico também traz emergências afetivas eminentemente relacionadas a sua configuração específica.

Érica, depois de ter se tornado terceirizada, embora ainda tenha necessidade de complementar a renda, seu caso revela uma dimensão específica no trabalho doméstico de diarista. Quando passou a trabalhar como terceirizada se desfez de suas clientes antigas e continuou apenas com a que tinha mais afinidade. Como ela mesmo diz: "essa família que eu trabalho a mais de doze anos eu almoço com eles na mesa. Eles falam 'Érica, você não é nossa diarista, você faz parte da nossa família'. São pessoas que chegam para mim, sentam comigo, desabafam coisas intimas da vida delas. Eu me sinto muito bem". Ela precisa completar a renda, isso é certo, mas a relação construída pesou na decisão de manter exclusivamente essa família empregadora.

Celina, traz um caso paradigmático nesse sentido. Praticamente retirada do trabalho de diarista ${ }^{53}$, escolheu a patroa de quem mais gostava para continuar a relação que, embora mediada pela prestação de serviço, veicula concomitantemente a sua necessidade de pôr-se

\footnotetext{
${ }^{53}$ Sua filha que também foi uma das entrevistadas nesta pesquisa se refere à mãe como aposentada.
} 
em movimento pelos problemas de saúde que tem, Celina teve um infarto, e a amizade com Vitória, construída apesar dos lugares sociais diferenciados a que pertencem.

\begin{abstract}
Eu por mim continuo trabalhando que eu não sei ficar parada. Acho que ficar parada é pior. Se eu puder ficar a toa de tudo eu não faço. Me falam: 'Celina você é boba demais, você é aposentada. Por que você ainda vai no Plano ${ }^{54}$ trabalhar?' 'Eu vou por amizade que eu tenho a minha patroa'. Ela tem eu como se fosse gente da família. Então, eu não posso deixar ela na mão. Eu vou lá e ajudo ela. E ela é mais nova do que eu. Aposentou agora esse ano. Tá com 55 anos. O marido dela também é mais novo do que eu (...). Eu ia lá toda semana, mas aposentou e diminuiu o salário dela. Ela me pagava R \$120,00 por dia. 'Mas eu não posso mais te pagar toda semana, então, você vem de quinze em quinze dias', [ela disse]. [Hoje] eu chego lá e tenho que pensar o que é que eu vou fazer, porque a casa já é tão limpinha. Porque ela é muito cuidadosa, deixa tudo cuidadinho. Chego limpo os vidros, limpo os banheiros, a cozinha, areio os azulejos. Cinco horas já limpei tudo, ainda passo a roupa dela. A roupa dela é pouquinha. Chego lá 9h da manhã saio as $5 \mathrm{~h}$.
\end{abstract}

Vitória, para quem Celina trabalha quinzenalmente, é aposentada pelo Banco do Brasil, o que significa que não é por questões econômicas que reduziu o trabalho de Celina por mês. De fato, a casa ficar tão limpa e organizada em duas semanas, não é tão improvável quando o fato de que mesmo depois de 2 semanas, quase não tem roupa para passar.

Naturalmente, é insustentável inclusive do ponto de vista moral, manter uma senhora de 74 anos que já teve sérios problemas de saúde executando tarefas potencialmente perigosas no seu caso. Basta pensar no que uma simples queda representaria para Celina. Quer contratem, sem que Celina o saiba, outra diarista para fazer a parte mais relevante do trabalho, ou quer o faça a própria Vitória (e o marido, quem sabe?), ao que tudo indica ela solicita os serviços de Celina por outras razões que colocam a margem o serviço prestado.

Embora tudo indique que ambas mantenham o vínculo empregatício por razões que passam ao largo do serviço prestado, sendo antes o mais importante a relação de amizade, tal relação não despreza o fato de pertencerem a estratos sociais diferenciados e terem experiências e perspectivas de vida diferentes. Quando perguntei a Celina se ela se senta à mesa com os empregadores durante as refeições, ela respondeu verbal e corporalmente como se lhe tivesse perguntado sobre comer algo nojento "a gente que é diarista não tem direito de sentar na mesa. Eles comem primeiro e depois que a gente vai comer e arruma a cozinha deles. Todos os trabalhos foi assim. Lugar em que eu fazia a comida eles comiam e depois eu ia tirar a mesa e ia comer". Até o banheiro que usa, conta Celina, é separado.

\footnotetext{
${ }^{54}$ Uma das regiões administrativas do Distrito Federal (ver anexo B).
} 
Apesar disso, a relação pessoal de Celina e Vitória aponta para uma característica muito discutida no trabalho doméstico de diarista e sua contraposição ao trabalho doméstico mensal. Diferentemente do que muitos pesquisadores e pesquisadoras têm escrito, não só existem relações de afetividade intensa no trabalho de diarista, como muitas vezes ele acaba se tornando o coroamento de uma relação bem-sucedida que não encontra precedentes no trabalho doméstico mensal. Isso está intimamente relacionado a relativa liberdade em se prestar o trabalho. Celina não teria condições em continuar com sua amiga se fosse contratada como mensalista.

O que leva a existir uma relação de trabalho que despreza o elemento financeiro? No caso de Celina, a justificativa repousa na recomendação médica que prescrevia que ela se mantivesse em movimento, já que tinha tido um infarto. Mas, como Celina mesma deixa claro, ela tem muitas outras coisas a fazer: ajuda os Vicentinos a cuidar de crianças carentes, cuida da mãe doente, cuida de ambas as casas, da sua e a da sua mãe. Não teria, assim, dificuldade em arrumar outra ocupação se a necessidade fosse só manter-se ocupada. Muito provavelmente qualquer outra ocupação que arrumasse também seria de cuidar.

Apesar de serem casos indiscutivelmente paradigmáticos, não se pode precisar o quando são ou não comuns. Além de Celina, tive oportunidade de conversar com outra trabalhadora domésticas do entorno. Constatei um outro caso de uma senhora aposentada que adicionalmente recebia pensão por morte do marido que continuou trabalhando para uma família em específico por nutrir relações que claramente, como no caso de Celina, não se dava por critérios financeiros, ela "ajudava" a patroa que não conseguiria cuidar da mãe doente sem ela, já que ao cuidar da casa liberava a cliente para a outra ocupação.

Ser talhada para as tarefas do cuidado não fazem Celina acrítica da realidade a sua volta. Em determinado momento da entrevista, tece considerações sobre a "porcança" das pessoas para quem trabalhou. Conclui: "já trabalhei em lugar que eles deixavam a pia da semana sem lavar nem uma vasilha. Sempre eles gostavam de acumular. O único lugar que não acumula as coisas é essa que eu trabalho agora". Note que Celina não manifesta nenhuma mágoa em relação a esses que aproveitaram muito dela, como disse em outro momento, mas quando já não necessitava do dinheiro, a questão financeira deixou de ser um dos elementos a serem levados em conta na escolha. Então, Celina escolheu também por amizade que tem pela patroa cuidadosa, na casa de quem sempre realizou tarefas específicas, ou seja, no lugar onde era mais bem tratada, não apenas do ponto de vista interpessoal, mas do ponto de vista 
da tarefa realizada. A socialização de uma vida inteira que vincula o sentimento de ser pessoa no mundo ao cuidado dos outros também teve grande influência, revelando aí um componente de gênero e de classe social na decisão de continuar trabalhando com Vitória.

Nessa medida, não é ocasional que essa relação mais forte baseie exatamente naqueles elementos que poderiam criar uma relação mais distanciada. Celina e Érica não poderiam continuar nutrindo os laços construídos com as suas patroas atrelados às relações de trabalho se tivessem de trabalhar por muitos dias na semana.

Muito provavelmente, porém, é o caso de Flávia o mais sintomático do trabalho afetivo e como ele integra as possibilidades oferecidas pelo trabalho de diarista, notadamente tornando possível uma rotina intensa de trabalho. Como entender o caso de Flávia e do carinho que manifesta em relação aos "meninos", para quem trabalha realizando a tarefa da semana em um dia, lava roupa a mão, faz comida e não pode se alimentar onde trabalha? Embora não deixe de mencionar a louça suja da semana inteira, Flávia deixa transparecer os valores que recupera do trabalho: a satisfação em ver seus meninos crescidos e empregados e a confiança da mãe que a deixa responsável pelos filhos são elementos que emergem na narrativa. Enquanto falava da louça suja, de lavar a roupa a mão, de sair de madrugada de casa e voltar à noite, de não poder comer no trabalho, não foi possível perceber qualquer julgamento de valor no seu relato. Flávia mantinha o tom de voz e a expressão facial neutros mesmo quando eu a interrompia mostrando-me um pouco impressionado com o que me contava.

Na sua história de vida, existem outros fatores que demandam a continuidade de Flávia no trabalho. O marido está desempregado, levando a renda familiar a depender dela. A filha entrou numa prestigiada universidade na capital. A valorização da conquista demanda esforço em criar a situação adequada para a filha estudar. No trabalho de Flávia, é perceptível a função de produção de bem-estar para as pessoas para quem trabalha, e a relações afetivas que nutre nele se baseiam na percepção que tem da importância do seu trabalho para a formação dos seus meninos e para que as pessoas para quem trabalhou chegassem onde chegaram.

Isso traz possibilidades ao trabalho doméstico enquanto trabalho afetivo, "lo que produce el trabajo afectivo, por tanto, es intangible, y no siempre es material, ya que lo que produce está ligado a los sentimientos, las emociones y las energías" (Gutiérrez-Rodríguez, 2013, 132). As possibilidades trazidas são possíveis pelo trabalho doméstico não ser um 
trabalho que produz um bem tangível. Flávia através das relações afetivas que nutre no trabalho encontra motivações através das quais o re-significa. Essa re-significação constitui a própria base sobre a qual Flávia consegue levar uma vida com tanto trabalho. Definir se tal artifício usado por Flávia está a serviço de uma forma intensificada de exploração me parece menos importante do que perceber que tal artifício está a serviço de que Flávia consiga dar conta da rotina dura que tem de realizar em função da necessidade de prover a família haja vista que a sua é a única renda familiar disponível na sua residência. 


\section{CONCLUSÃO}

Essa dissertação parte de transformações no trabalho doméstico que vem ocorrendo nos últimos anos para, a partir da colisão entre as experiências das trabalhadoras e dos debates suscitados por essas transformações, refletir sobre algumas deficiências desses debates e sobre as consequências dos diferentes vínculos (trabalho mensal ou de diarista) assumidos pelas mulheres que o executam.

As experiências das próprias trabalhadoras permitem perceber, em primeiro lugar, o que significam as conquistas trazidas pela migração, considerando a perspectiva ascendente que as entrevistadas têm sobre sua trajetória: não apenas as oportunidades econômicas encontradas, o êxodo rural, mas também a possibilidade de reconstrução de suas vidas depois de deixarem maridos ou de terem se tornado mães solteiras; os significados que atravessam o relacionamento afetivo entre trabalhadoras e empregadores e o papel da família da trabalhadora como pivô de várias transformações que têm lugar nas suas histórias de vida.

O lugar subalterno ocupado pela população negra, embora traga marcas de um processo histórico que tem como um de seus principais capítulos a escravidão, é atualizado pela ação de instituições, como leis. No caso do trabalho doméstico, tal atualização se deveu ao fato de se manter por mais de 70 anos a condição de desigualdade dessa ocupação em relação as outras no mercado de trabalho.

O trabalho doméstico consiste no entroncamento entre articulações de raça, gênero e classe social de um lado e, de outro, um lugar social subestimado que até pouco tempo era distinguido de outras profissões por não contar com cobertura legal plena, distinção que repercutia na vulnerabilização das mulheres empregadas nele.

Quando o trabalho doméstico se torna equiparável a outras categorias no mercado de trabalho pela aprovação da Emenda Constitucional 72, de 2013, sinalizando o fim de uma era maldita, outro movimento recente é sentido como ameaça à promessa de novos tempos: a diarização do trabalho doméstico, que faz jus a um conjunto mais restrito de direitos, dentre os quais não se inclui nenhuma proteção do vínculo de trabalho - fundo de garantia e seguro desemprego - nem se inclui qualquer direito a descanso - férias, descanso semanal -, além de não ter $13^{\circ}$. Em relação aos direitos que possui, esses dependem ainda de que se torne contribuinte autônoma, o que configura mais um obstáculo em face da falta de familiaridade com os meios exigidos para tal e da própria insegurança vivida por se dedicar a um trabalho 
sem qualquer segurança o que faz com que o dinheiro que por ventura sobre seja convertido para outros fins, seja em benefício imediato ou mesmo numa reserva de segurança.

Não se deve inferir que não exista outro caminho para a falta de direitos que acomete diaristas. O Tribunal Superior do Trabalho reconheceu, no caso de diarista que presta serviço para empresa, a existência de vínculo empregatício e, portanto, da dívida de verbas que digam respeito a tal vínculo ${ }^{55}$. A distinção entre diaristas e mensalistas é parte de uma retórica jurídica que estabeleceu as diferenças entre umas e outras com base em critérios que sequer eram consensuais.

Nesse cenário que difere mensalistas de diaristas, a noção de precarização tem sido usada para falar do crescimento do polo do trabalho doméstico que emprega diaristas, que conta com pouca proteção frente ao encolhimento do polo resguardado por direitos. De fato, o emprego dessa noção faz sentido à luz do legalmente prescrito, mas se torna estranha ao trabalho doméstico se analisada diante da efetivação da norma. Nesse sentido, cabe ressaltar que o trabalho se tornou legalmente reconhecido, mas as mulheres ocupadas nele ainda, na sua maioria, não têm carteira assinada nem contribuem para o INSS, as únicas portas de entrada disponíveis, nesse caso, para se conseguir qualquer proteção ou direitos garantidos por lei. Portanto, a mudança de trabalhadoras da modalidade mensal para a diária no trabalho doméstico não significa que estejam deixando a proteção legal, já que muitas vezes já não a tinham enquanto mensalistas.

Em oposição a essa noção, rendimento e carteira assinada são argumento frequentemente usados favoravelmente ao processo de diarização porque nessa modalidade o rendimento geralmente é maior e o percentual de contribuintes previdenciárias, embora mais frequente entre mensalistas, cresce a um ritmo mais intenso entre diaristas.

Esses debates, no entanto, passam ao largo do que o trabalho doméstico acarreta para a vida das mulheres que o executam. O Distrito Federal tem o maior percentual de trabalhadoras domésticas migrantes do país. Cerca de $85 \%$ das mulheres ocupadas na profissão vem de outras unidades da federação. A migração não é só empreendida com finalidade de buscar melhores condições de vida apenas do ponto de vista econômico. Algumas entrevistadas, separadas do marido, buscavam um recomeço para suas vidas, outra, ainda adolescente e com filho recém-nascido, preferiu a sua independência a voltar para a casa de sua mãe. As-

\footnotetext{
${ }^{55}$ Disponível em: http://www.guiatrabalhista.com.br/noticias/vinculoempregaticiodiarista.htm.
} 
sim, a migração acena com outras possibilidades que se tornam muito significativas especialmente pelo que isso acarreta para mulheres em termos de conquista de autonomia e de melhores condições econômicas, sendo esta última uma dimensão que não pode ser desprezada, posto que muitas dessas migrantes continuam tendo responsabilidades a cumprir auxiliando no sustento de pessoas de outros estados e regiões e, portanto, migram considerando também a viabilidade econômica.

No contexto de migração no trabalho doméstico, a configuração da migração influencia a forma como as entrevistadas se estabeleceram na capital e influencia na forma como vão ser contratadas como trabalhadoras domésticas: residentes ou externas. As entrevistadas que migraram sem família acabaram por se tornar trabalhadoras domésticas residentes. Isso significou, nos casos em que tinham filhos, lançar mão da maternidade compartilhada, deixando filhos e filhas com mães e pais em outros estados para poderem trabalhar e mandar ajuda para o cuidado dos filhos. Só quando deixaram a modalidade de trabalho doméstico como residentes conseguiram formar sua família e voltar a reunir filhos e filhas.

Flávia e Zélia se tornaram diaristas depois de terem sido demitidas do último trabalho que tiveram registradas. Foi um período muito difícil lembra Zélia. Ambas eram terceirizadas. Nessa medida, pela experiência adquirida, parecem carregar as marcas que as fazem reconhecer a sua posição flutuante no mercado de trabalho não-doméstico - contudo feminizado - na promoção de uma dupla segurança: a segurança do direito e a segurança do rendimento. No primeiro caso, pelo trabalho com carteira, no segundo, pela diária. Sabem que, trabalhando apenas registradas, caso percam o emprego, perdem toda a fonte de renda. Já, com as diárias, vão-se clientes e voltam clientes, mas dificilmente ficam sem trabalho a semana toda. Então, com as diárias sempre é possível dar um jeito. Com o trabalho registrado, não...

Érica também deixou o trabalho mensal involuntariamente, continuaria se pudesse, pelas ligações constituídas com parte da família empregadora. Conseguindo elevar consideravelmente seu poder aquisitivo fazendo diárias, passou a desfrutar menos do convívio da família. Ao perceber o impacto que isso estava gerando na dissolução da sua família, deixou as diárias para se tornar terceirizada. Hoje ganha muito menos, mas tem qualidade de vida melhor. Não precisa mais ter medo de ir no médico e sair de lá com atestado. Sabe que pode ficar "encostada" que isso não significa que sua família vá "passar fome". 
Cecília, que trabalhava por mês e era registrada, deixou o serviço para cuidar do filho pequeno. Volta a trabalhar esporadicamente para não descuidar da criança pequena. Quanto o filho já estava maior, passa a trabalhar em todos os dias, tendo um bom rendimento como diarista. No entanto, agora, com a idade chegando, vai voltar a ser mensalista, ganhando bem menos, mas com direito a férias, a décimo-terceiro, entre os demais benefícios assegurados.

Cleide não abandona o trabalho doméstico mensal em que é registrada, embora tivesse vontade de fazê-lo. Tendo compreendido depois de se mudar para a Capital Federal a importância de se ter registro em carteira, não quer mais trabalhar sem ele. Já teve oportunidade de ter outro emprego, não deixa o atual porque pensa no patrão, bem como também os filhos são uma das razões que a levaram a se "acomodar", conforme diz, a trabalhar onde está, já que está perto deles e de casa, podendo ser solicitada caso necessário.

Ângela e Antônia, ao deixarem a condição de trabalhadoras domésticas residentes e passarem a diaristas, adquirem condições de reunir a família e, como aconteceu também com Érica, de se casarem. Antônia fala de forma indistinta das relações que nutria como mensalista e das que nutre como diarista. Ângela diz que o que a fez se tornar diarista foi o fato de que não tinha direitos mesmo, então, valia a pena ganhar um pouco mais.

Assim, não se pode dizer propriamente que ser diarista se constituiu exclusivamente como opção. Dentre os seis casos em que houve transição, isso aconteceu para Antônia, Ângela e Cecília. Para Flávia, Zélia e Érica foram razões alheias a sua vontade que as levaram às diárias.

Como diaristas, a possibilidade de gerir o trabalho permite que ele seja executado em menos tempo que o mensal, abrindo espaço para ganhos maiores, que podem ou não se realizar a contento. As perspectivas positivas sobre o trabalho doméstico de diarista se baseiam nessa possibilidade. Flávia e Zélia aproveitaram essa oportunidade. Zélia e Flávia, trabalham um período como diaristas, Flávia de manhã e Zélia à tarde. Após terem deixado o trabalho doméstico mensal, passaram a fazer diárias e a conciliá-las com outras atividades. No caso de Zélia foi com o trabalho em uma academia a poucas quadras de sua casa. Flávia, que mora em Sobradinho concilia com o trabalho no colégio em outra região administrativa do Distrito Federal. Ambas conciliam as diárias com trabalhos registrados como faxineiras; ambas trabalham mais horas e ganham menos por essa segunda jornada de trabalho.

A partir das entrevistas se percebe que diaristas executam muito mais trabalho que mensalistas. Uma casa pode acumular todos os trabalhos de casa a serem feitos na semana 
inteira para que a diarista dê conta de tudo no único dia em que presta serviço naquela residência. Disso se percebe que: 1) há uma discrepância entre o rendimento que se ganha a mais e o quando se trabalha a mais nos casos em que os salários estão próximos da média; 2) no caso em que trabalhadoras conseguem ter um rendimento consideravelmente superior, muitas vezes isso se torna possível por um trabalho hercúleo que praticamente elimina a sua convivência com a família.

É recorrente falas sobre a dificuldade que trabalhadoras diaristas enfrentam para se tornarem contribuintes autônomas. Dificuldade que passa pela falta de familiaridade com os mecanismos para se tornar contribuinte, e também pelo fato de que outros deveres são priorizados em relação a pagar a contribuição. Ainda que pagassem a contribuição, esta não lhes garante todos os direitos. Sendo as trabalhadoras do Distrito Federal na maior parte egressas de outros estados, não ter direito a férias significa que muitas vezes diaristas passam anos sem ver as famílias distantes. Em relação aqueles direitos que são garantidos pela contribuição individual, nem sempre as trabalhadoras se sentem seguras em relação a eles. Cecília por exemplo, embora seja contribuinte autônoma, menciona o fato de que se tornar mensalista lhe trará segurança caso fique doente.

Nessas circunstâncias, a família aparece como pivô da busca por segurança. Paradigmaticamente, temos o caso de Érica que revela que, como diarista, tinha medo de ir ao médico e sair de lá com atestado, pelas implicações que isso trazia para sua atividade e para o bem-estar da sua família por não poder trabalhar.

As relações pessoais inerentes ao trabalho de diarista não são, em princípio, percebidas pelas entrevistadas como contendo qualquer especificidade em relação as cultivadas no trabalho doméstico mensal, embora existam especificidades. Tratando, no entanto, do caso geral, a partir da noção de trabalho doméstico como trabalho afectivo de Gutiérrez-Rodríguez, afetos e emoções resultam da produção do espaço aprazível e da eliminação de disputas que conflito em torno da execução do trabalho doméstico poderia trazer caso se tentasse promover a equidade de participação de homens e mulheres nos afazeres domésticos. A partir das manifestações exteriorizadas de apreço percebidas pelas trabalhadoras, elas se envolvem com a atividade a ser executada nutridas pelo sentimento de contentamento provocado.

As relações pessoais no trabalho doméstico, bem como os ganhos extracontratuais que lhe são inerentes, ora são vistas como motivo do descumprimento de prescrições legais 
que beneficiam trabalhadoras ora são vistas como estratégias instrumentalizadas por trabalhadoras diante de situações de necessidade e de desigualdade social. Nessa medida, chama atenção que no trabalho doméstico de diarista algumas das entrevistadas não se beneficiavam de nenhuma das duas formas.

Muitas vezes mesmo quando a pessoalidade das relações assume a forma de ganhos extracontratuais, estes não são um valor em si, mas um símbolo das relações constituídas, como dá a entender Antônia ao dizer que "se sente como da família dos empregadores" não pelos ganhos que obtém no trabalho, mas pela confiança que eles manifestam através da coisa ou da ajuda dada. Assim, o ganho não é mais do que a externalização dos afectos de que fala Gutiérrez-Rodrigues. Se pensarmos em todos os elementos presentes nas narrativas, desde a acumulação de uma pesada carga de trabalho, assédio, preocupação com a própria saúde e o que isso acarreta para o bem-estar da própria família, é possível perceber que o trabalho afetivo é um artifício que possibilita às prestadoras de serviços domésticos explorar as brechas das relações pessoais fornecidas no interior dos lares em que trabalham para contornar situações que levam ao cansaço, que às levam ao trabalho intenso, que as levam a ser objeto de assédio e a tipos diferentes de maus tratos.

Desse modo, verifica-se que a prática do esforço de identificação derivado das conquistas trazidas desde a migração, das relações afetivas cultivadas no trabalho e da busca por estabilidade através de uma relação de emprego protegida em atenção às necessidades da família configuram fatores que na prática cotidiana das entrevistadas se destacam como critérios valorizados nesse universo que cerca o trabalho doméstico no Distrito Federal. 


\section{BIBLIOGRAFIA}

ABRAMO, Laís. Desigualdades de gênero e raça no mercado de trabalho brasileiro. Ciência e Cultura, v. 58, n. 4, p. 40-41, 2006.

ASSIS, Gláucia de Oliveira. Mulheres migrantes no passado e no presente: gênero, redes sociais e migração internacional. Estudos Feministas, p. 745-772, 2007.

ÁVILA, Betânia; FERREIRA, Verônica. Trabalho Produtivo e Reprodutivo e o Desafio para a Igualdade de Gênero. Chesf: Recife, 2012.

ÁVILA, Maria Betânia. Divisões e tensões em torno do tempo do trabalho doméstico no cotidiano. Revista do Observatório Brasil da Igualdade de Gênero. Edição especial Tema: Trabalho e Gênero. Brasília: Secretaria Especial de Políticas para as Mulheres, 2010.

ALMEIDA, Tânia Mara Campos de; BANDEIRA, Lourdes Maria. Mulheres Invisibilizadas: trabalho abjeto. In: XXVIII Congresso Internacional da ALAS, Recife, 2011.

BERNARDINO-COSTA, Joaze. Decolonialidade e interseccionalidade emancipadora: a organização política das trabalhadoras domésticas no Brasil. Sociedade e Estado, v. 30, n. 1, p. 147-163, 2015.

BERNARDINO-COSTA, Joaze. Trabalhadoras Domésticas no Distrito Federal e suas Condições de Trabalho. In: MORI, Natalia et al (org.). Tensões e experiências: um retrato das trabalhadoras domésticas de Brasília e Salvador. Brasília: CFEMEA: MDG3 Fund, 2011.

BERNARDINO-COSTA, Joaze. Sindicatos das trabalhadoras domésticas no Brasil: teorias da descolonização e saberes subalternos. Tese de Doutorado, Sociologia, Universidade de Brasília, 2007.

BIROLI, Flávia. Gênero e família em uma sociedade justa: adesão e crítica à imparcialidade no debate contemporâneo sobre justiça. Revista Sociologia e Política, Curitiba, v. 18, n. 36 , p. 51-65, junho 2010.

BORGES, Antonádia. Tempo de Brasília: etnografando lugares-eventos da política. Relume Dumará, 2003.

BRASIL. Constituição (1988). Emenda constitucional n. ${ }^{\mathbf{0}} \mathbf{7 2}$, de 2 de abril de 2013. Altera a redação do parágrafo único do art. $7^{\circ}$ da Constituição Federal para estabelecer a igualdade de direitos trabalhistas entre os trabalhadores domésticos e os demais trabalhadores urbanos e rurais.

Decreto $\mathbf{n}^{\mathbf{0}}$. 6.481, de 12 de junho de 2008. Regulamenta os artigos $3^{\circ}$, alínea "d", e $4^{\circ}$ da Convenção 182 da Organização Internacional do Trabalho (OIT) que trata da proibição das piores formas de trabalho infantil e ação imediata para sua eliminação, aprovada pelo Decreto Legislativo $\mathrm{n}^{\circ}$. 178, de 14 de dezembro de 1999, e promulgada pelo Decreto $\mathrm{n}^{\circ}$. 3.597, de 12 de setembro de 2000 , e dá outras providências. 
Decreto $\mathbf{n}^{\mathbf{0}}$. 95.247, de 17 de novembro de 1987. Regulamenta a Lei no. 7.418, de 16 de dezembro de 1985, que institui o vale-transporte, com a alteração da Lei ${ }^{\circ}$. 7.619, de 30 de setembro de 1987

Decreto n ${ }^{\circ} \mathbf{7 1 . 8 8 5}$, de 09 de março de 1973. Aprova o Regulamento da Lei $n^{\circ}$. 5.859, de dezembro de 1972, que dispõe sobre a profissão de empregado doméstico, e dá outras providências. do Trabalho.

Decreto-Lei $\mathbf{n}^{\mathbf{0}} \mathbf{. 5 . 4 5 2}$, de $1^{\text {a }}$ de maio de 1943. Aprova a Consolidação das Leis

Lei $\mathbf{n}^{\mathbf{0}}$. 11.324, de 19 de julho de 2006. Altera dispositivos das Leis $n^{\circ} \mathrm{s} .9 .250$, de 26 de dezembro de 1995, 8.212, de 24 de julho de 1991, 8.213, de 24 de julho de 1991, e 5.859 , de 11 de dezembro de 1972; e revoga dispositivo da Lei $\mathrm{n}^{\circ}$. 605, de 5 de janeiro de 1949.

Lei no $\mathbf{~ 1 0 . 2 0 8 , ~ d e ~} 23$ de março de 2001. Acresce dispositivos à Lei $n^{\circ} .5 .859$, de 11 de dezembro de 1972, que dispõe sobre a profissão de empregado doméstico, para facultar o acesso ao Fundo de Garantia do Tempo de Serviço - FGTS e ao seguro-desemprego.

Lei $\mathbf{n}^{\circ} \mathbf{. 9 . 0 2 9} / 95$, de 13 de abril de 1995. Proíbe a exigência de atestados de gravidez e esterilização, e outras práticas discriminatórias, para efeitos admissionais ou de permanência da relação jurídica de trabalho, e dá outras providências.

Lei $\mathbf{n}^{\mathbf{0}}$. 7.619, de 30 de setembro de 1987. Altera dispositivos da Lei ${ }^{\circ}$. 7.418, de 16 de dezembro de 1985, que instituiu o vale-transporte.

Lei $\mathbf{n}^{\circ}$. 5.859, de 11 de dezembro de 1972. Dispõe sobre a profissão de empregado doméstico e dá outras providências.

Lei Complementar $\mathbf{n}^{\mathbf{0}} \mathbf{1 5 0}$, de $1^{\circ}$ de junho de 2015. Aprova o Regulamento da Lei $\mathrm{n}^{\circ}$. 5.859, de dezembro de 1972, que dispõe sobre a profissão de empregado doméstico, e dá outras providências.

BRENNAN, Vitória. 2004. The Transmission of Affect. Ítaca: Cornell University Press.

BRITES, Jurema; PICANÇO, Felícia. O emprego doméstico no Brasil em números, tensões e contradições: alguns achados de pesquisas. Revista Latino-americana de Estudos do Trabalho, Ano 19, n. 31, p. 131-158, 2014.

BRITES, Jurema. Afeto e desigualdade: gênero, geração e classe entre empregadas domésticas e seus empregadores. Cadernos Pagu, n. 29, p. 91-109, 2007.

BRITES, Jurema; LISBOA, MEA; MALUF, S. Serviço doméstico: um outro olhar sobre a subordinação. Gênero, cultura e poder, p. 111-143, 2004.

BRITES, Jurema. Serviço Doméstico: elementos políticos de um campo desprovido de ilusões. CAMPOS-Revista de Antropologia Social, v. 3, 2003. 
BRITES, Jurema. Afeto, desigualdade e rebeldia: bastidores do serviço doméstico. 2001. Tese de Doutorado. Disertación de doctorado en Antropologia Social, Universidade Federal do Rio Grande do Sul. 2000

BRUSCHINI, Maria Cristina Aranha. Trabalho e gênero no Brasil nos últimos dez anos. Cadernos de pesquisa, v. 37, n. 132, p. 537-572, 2007.

BRUSCHINI, Cristina. Trabalho doméstico: inatividade econômica ou trabalho não-remunerado? Revista Brasileira de Estudos de População, São Paulo, v. 23, n. 2, p. 331353, Dec. 2006.

BRUSCHINI, Cristina. Gênero e Trabalho Feminino no Brasil: novas conquistas ou persistência da discriminação? Brasil, 1985 a 1995- Paper apresentado no Seminário Trabalho e Gênero: Mudanças, permanências e desafios. GT População e Gênero Nepo/Unicamp, São Paulo,1998.

BRUSCHINI, Cristina; LOMBARDI, Maria Rosa. A bipolaridade do trabalho feminino no Brasil contemporâneo. Cadernos de pesquisa, v. 110, p. 67-104, 2000.

CASTRO, Mary Garcia. Alquimia de categorias sociais na produção dos sujeitos políticos. Revista Estudos Feministas, v. 10, p. 57-74, 1992.

CFEMEA - Centro Feminista de Estudos e Assessoria. Direitos das trabalhadoras domésticas: comentários sobre a legislação atual, conquistas e lacunas. Brasília: Cfemea, 2007.

CHANEY, Elsa M. et al. Muchacha, cachifa, criada, empleada, empregadinha, sirvienta, y... más nada: trabajadoras domésticas en América Latina y el Caribe. 1993.

CHAPLIN, David. Domestic service and industrialization. Comparative Studies in Sociology, v. 1, n. 97, p. 127, 1978.

COSER, Lewis A. Servants: the obsolescence of an occupational role. Social Forces, v. 52, n. 1, p. 31-40, 1973.

COLEN, Shelle. Like a mother to them: stratified reproduction and West Indian Childcare workers and employers in New York. In: GINSBURG, Faye \& RAPP, Rayna. (org.). Conceiving the new world order: the global politics at reproduction. Berkley: University California Press, p. 78-102, 1995.

COLLINS, Patricia Hill. Aprendendo com a outsider within: a significação sociológica do pensamento feminista negro. Sociedade e Estado, v. 31, n. 1, p. 99-127, 2016.

CRENSHAW, Kimberle W. A intersecionalidade na discriminação de raça e gênero. VV. AA. Cruzamento: raça e gênero. Brasília: Unifem, 2004.

DULTRA, Eneida Vinhaes; MORI, Natália. Trabalhadoras domésticas em luta: direitos, igualdade e reconhecimento. Centro Feminista de Estudos e Assessoria, 2008. 
FARIAS, Zaíra A. Domesticidade: "Cativeiro" Feminino? Rio de Janeiro:Achiamé/CMB, 1983.

FERNANDES, Florestan. A integração do negro na sociedade de classes: no limiar de uma nova era. Globo Livros, 2008.

FIGUEIREDO, Angela. Condições e Contradições do Trabalho doméstico em Salvador. In: MORI, Natalia et.al. (org.). Tensões e experiências: um retrato das trabalhadoras domésticas de Brasília e Salvador. Brasília: CFEMEA: MDG3 Fund, 2011.

FRAGA, Alexandre Barbosa. De empregada a diarista: as novas configurações do trabalho doméstico remunerado. Rio de Janeiro: Multifoco, 2013.

GLENN, Evelyn N. From Servitud to Work: historical continuities in the racial of paid reproductive labor. 1992

GUTIÉRREZ-RODRÍGUEZ, Encarnación. Trabajo doméstico-trabajo afectivo: sobre heteronormatividad y la colonialidad del trabajo en el contexto de las políticas migratorias de la UE. Revista Estudios Sociales, Bogotá, n. 45, p. 123-134, jan./abr. 2013.

HIRATA, Helena. Gênero, classe e raça Interseccionalidade e consubstancialidade das relações sociais. Tempo social, v. 26, n. 1, p. 61-73, 2014.

HIRATA, Helena; KERGOAT, Danièle. Novas configurações da divisão sexual do trabalho. In: Cadernos de Pesquisa, v. 37, n. 132, p. 595-609, set./dez. 2007.

HOFFMANN, Rodolfo; LEONE, Eugênia Troncoso. Participação da mulher no mercado de trabalho e desigualdade da renda domiciliar per capita no Brasil: 1981-2002. Nova economia, v. 14, n. 2, 2009.

HONDAGNEU-SOTELO, Pierrette. Domestica: Immigrant workers cleaning and caring in the shadows of affluence. Univ of California Press, 2001.

hooks, bell. Mulheres Negras: Moldando a teoria feminista. Revista Brasileira de Ciência Política, n. 16, p. 1-17.

IPEA - Instituto Brasileiro de Geografia Estatística. Expansão dos direitos das trabalhadoras domésticas no Brasil. Nota técnica, n. 10, 2012.

LIBARDONI, Paulo José; SILVEIRA, Gabriel Eidelwein . Empregadas domésticas e a PEC das prerrogativas trabalhistas. In: Rodrigo Nuss; Kelly Gianezini. (Org.). Série Estudos contemporâneos em ciências jurídicas e sociais. 2ed.Campo Novo do Parecis: ATC, 2014.

MAGALHÃES, Nancy Aléssio.Memórias de Cá e de Lá - Paranoá/DF. Cor, BETACAM, 44', 1998, DF (documentário). 
MAGALHÃES, Nancy Aléssio; NUNES, José Walter; PAIVA-CHAVES, VITÓRIA. Cadê Brasília que construímos? Série Abrigos da Mémória. Cor, VHS/NTSC, 50', 1993, DF (documentário).

MAGALHÃES, Nancy Aléssio; NUNES, José Walter; PAIVA-CHAVES, VITÓRIA. Mãos à obra em Brasília. Série Abrigos da Mémória. Cor, VHS/NTSC, 46' (?), 1995, DF (documentário);

MELLO, Hildete Pereira de. De criadas a trabalhadoras. Estudos Feministas, v. 6, n. 2, p. $323,1998$.

MENDOZA, Breny. La epistemología del sur, la colonialidad del género y el feminismo latinoamericano. Aproximaciones críticas a las prácticas teórico-políticas del feminismo latinoamericano, v. 1, p. 19-36, 2010.

MORI, Natalia et al. Tensões e experiências: um retrato das trabalhadoras domésticas de Brasília e Salvador. 2011.

MOROKVASIC, Mirjana. Birds of Passage are also Women. The International migration review, v. 18, n. 4, p. 886-907, 1984.

MOTTA, Alda Britto da. Emprego doméstico: revendo o novo. 1992.

MOTTA, Alda Brito da. Visão de mundo da empregada doméstica: um estudo de caso. 1977

NUNES, Christiane Girar Ferreira; SILVA, Pedro Henrique Isaac. Entre o prescrito e o real: o papel da subjetividade na efetivação dos direitos das empregadas domésticas no Brasil. Soc. Estado., Brasília, v. 28, n. 3, Dec. 2013.

NUNES, Christiane Girard Ferreira. Cidadania e Cultura: o universo das empregadas domésticas em Brasília (1970-1990). 1993. Tese de Doutorado. Tese de doutoramento apresentada ao Programa de Pós Graduação em Sociologia da Universidade de Brasília.

NUNES, José Walter. Vila Planalto (19'). Série Nossa História, Nosso Patrimônio. Cor, 19', 2000a, DF (documentário).

NUNES, José Walter. Metropolitana (22'). Série Nossa História, Nosso Patrimônio. Cor, 22', 2000b, DF (documentário).

NUNES, José Walter. Núcleo Bandeirante (15'). Série Nossa História, Nosso Patrimônio. Cor, 15' 2000c, DF (documentário).

NUNES, José Walter. Batalhas pelo Patrimônio, Batalhas pela História. Paranóa DF. Cor, 29’30, 1999, DF (documentário). 
OIT/ILO - International Labour organization. Domestic workers across the world: global and regional statistics and the extent of legal protection / International Labour Office - Geneva: ILO, 2013.

OKIN, Susan Moller. Gênero, o público e o privado, o público e o privado. Estudos Feministas, 2008,

OLIVEIRA, Francisco. A economia brasileira: crítica a razão dualista. Rio de Janeiro: Vozes, 1981.

OLIVEIRA, Nancy Mahra de Medeiros Nicolas. Trabalho doméstico: ainda em busca da igualdade. Revista eletrônica [do] Tribunal Regional do Trabalho da $9^{a}$ Região, Curitiba, PR, v. 5, n. 52, p. 26-32, jul. 2016.

ORTNER, Sherry \& WHITEHEAD, Harriet. Accounting for sexual meanings. In: Sexual Meanings. The cultural construction of gender and sexuality, Cambridge, Cambridge University Press, 1981.

POCHMANN, Marcio. Mercado geral de trabalho: o que há de novo no Brasil? Parcerias estratégicas, v. 11, n. 22, p. 121-144, 2010.

PINHEIRO, Luana; FONTOURA, Natália; PEDROSA, Cláudia. Situação das trabalhadoras domésticas no país. In: CASTRO, Jorge Abrahão de; ARAÚJO, Herton Ellery (Org.). Situação social brasileira: monitoramento das condições de vida. 2012.

SAFFIOTI, Heleieth Iara Bongiovani. Ontogênese e filogênese do gênero: ordem patriarcal de gênero e a violência masculina contra mulheres. Séries Estudos e ensaios - Ciências Sociais/FLACSO/ Faculdade Latino-Americana de Ciências Sociais, jun. 2009.

SAFFIOTI, Heleieth Iara Bongiovani. Emprego doméstico e capitalismo. Editora Vozes, 1978.

SALAS, Carlos; LEITE, Márcia. Segregação setorial por gênero: uma comparação BrasilMéxico. In: COSTA, Albertina O.; SORJ, Bila; BRUSCHINI, Cristina; HIRATA, Helena (org.). Mercado de Trabalho e Gênero: Comparações Internacionais. Rio de Janeiro: FGV, 2008 .

SANCHES, Solange. Trabalho doméstico: desafios para o trabalho decente. Estudos feministas, v. 17, n. 3, p. 879-888, 2009.

SEGATO, Rita Laura. Raça é signo. Departamento de Antropologia, Universidade de Brasília, 2005.

SILVA, Adielson da Costa. A evolução da previdência social rural no Brasil: a construção do segurado especial. 2013.

SMITH, Barbara (Ed.). Home girls: a black feminist anthology. New York: Kitchen Table, Women of Color Press, 1983. 
SORJ, Bila. Arenas de cuidado nas interseções entre gênero e classe social no Brasil. Cadernos Pesquisa, São Paulo, v. 43, n. 149, p. 478-491, Aug. 2013.

STOLCKE, Verena. Mulheres e trabalho. Estudos Cebrap, v. 26, p. 81-117, 1980.

VIEIRA, Nanah Sanches. O trabalho da babá: trajetórias corporais entre o afeto, o objeto e o abjeto. 2014. 151 f., il. Dissertação (Mestrado em Sociologia)—Universidade de Brasília, Brasília, 2014. 


\section{ANeXo A: Vocabulário}

Aviso Prévio: O aviso prévio é a notificação dada pelo empregador ou pelo empregado sobre a sua intenção de romper o vínculo empregatício; garantindo que a empresa possa procurar outro funcionário ou que o funcionário possa encontrar uma nova colocação no mercado de trabalho.

É obrigatória a antecedência de no mínimo 30 dias e tanto o trabalhador quanto o empregador podem optar pelo aviso prévio trabalhado ou indenizado.

$\mathrm{O}$ aviso prévio trabalhado é aquele no qual o empregado trabalha até a data limite programada para findar seu vínculo com a empresa. Caso o trabalhador peça demissão e não conceda esse período trabalhado ao seu empregador para que este arrume outro funcionário para sua posição, terá uma indenização descontada na sua rescisão contratual. Caso a empresa não conceda o aviso prévio para o empregado demitido arrumar outro emprego, terá de indenizar o empregado. A indenização é proporcional ao que o funcionário ganhava quando estava em serviço.

Carteira de Trabalho (CTPS): A Carteira de Trabalho e Previdência Social é um documento, semelhante ao passaporte, no qual vem registrados todos os trabalhos no setor privado em que determinada pessoa esteve empregada. Ter a carteira de trabalho assinada garante ao trabalhador ou trabalhadora os direitos trabalhistas adquiridos. Mas não é o caminho exclusivo para se ter acesso aos direitos do trabalho. Por exemplo, trabalhadores que contribuem para o INSS (Previdência Social) por conta própria e trabalhadores do serviço público de qualquer esfera (municipal, estadual ou federal) tem outra forma de registro de trabalho e previdência social (sendo a previdência social diferenciada só para os servidores públicos). Portanto, nesses dois casos os empregados não têm seus registros em carteira de trabalho, embora tenham direitos assegurados.

FGTS: O Fundo de garantia por tempo de serviço é um depósito que o empregador faz mensalmente numa conta de um banco federal. O depósito corresponde a $8 \%$ do valor do salário da trabalhadora ou do trabalhador. Se o trabalhador for demitido sem justa causa, isso não constituirá razão suficiente para sacar o fundo (no entanto, o trabalhador poderá 
sacar o fundo por outras razões como em casos de doença, catástrofes naturais, entre ou$\operatorname{tras}^{56}$ ), mas se for demitido sem justa causa, o empregador deverá pagar uma multa de $40 \%$ sobre o valor total do fundo a título de indenização para o trabalhador. Neste caso (de demissão sem justa causa) o trabalhador poderá sacar o fundo imediatamente.

INSS e Previdência Social ${ }^{57}$ : O Instituto Nacional de Seguro Social é um órgão do Ministério da Previdência Social, ligado ao Governo. É responsável pelos pagamentos das aposentadorias e demais benefícios dos trabalhadores brasileiros que contribuem com a Previdência Social, com exceção dos servidores públicos. A contribuição para o INSS garante o recebimento da aposentadoria e o auxílio-doença em caso de afastamento do serviço por motivo de saúde.

São garantias asseguradas aos contribuintes da Previdência Social: I) cobertura dos eventos de doença, invalidez, morte e idade avançada; II) proteção à maternidade, especialmente à gestante; III) proteção ao trabalhador em situação de desemprego involuntário; IV) salário-família e auxílio-reclusão para os dependentes dos segurados de baixa renda; V) pensão por morte do segurado, homem ou mulher, ao cônjuge ou companheiro e dependentes.

A contribuição é tanto do trabalhador quanto do empregador. Cada um paga, no caso do trabalho doméstico que tem uma taxa reduzida, o equivalente a $8 \%$ do salário das trabalhadoras.

Seguro-desemprego ${ }^{58}$ : O seguro-desemprego tem o objetivo de garantir assistência financeira temporária para o trabalhador que foi demitido sem justa causa. Para recebê-lo, além de ter sido demitido sem justa causa, é necessário permanecer na condição de desempregado.

O seguro-desemprego é assegurado à trabalhadora doméstica que apresentar a carteira de trabalho em que comprove que trabalhou por pelo menos 15 meses no período de dois anos antes da demissão, independentemente de ter sido tudo num único emprego.

Antes da Emenda, o trabalhador tinha direito a seguro-desemprego apenas se o empregador tivesse optado por pagar o FGTS. Esse pagamento até a Emenda não era obrigatório.

\footnotetext{
56 Veja as outras razões que permitem trabalhadores e trabalhadoras sacarem o FGTS no site: http://www.fgts.gov.br/perguntas/trabalhador/pergunta07.asp

${ }^{57}$ http://www.previdencia.gov.br/perguntas-frequentes/previdencia-social/

${ }^{58}$ https://www.financaspraticas.com.br/pessoais/vida/inesperado/4.php
} 


\section{ANEXO B: MAPAS}

\section{REgiões AdMinistrativas (RA) DE BRASíLIA}

Figura 1: MAPA DO DISTRITO FEDERAL

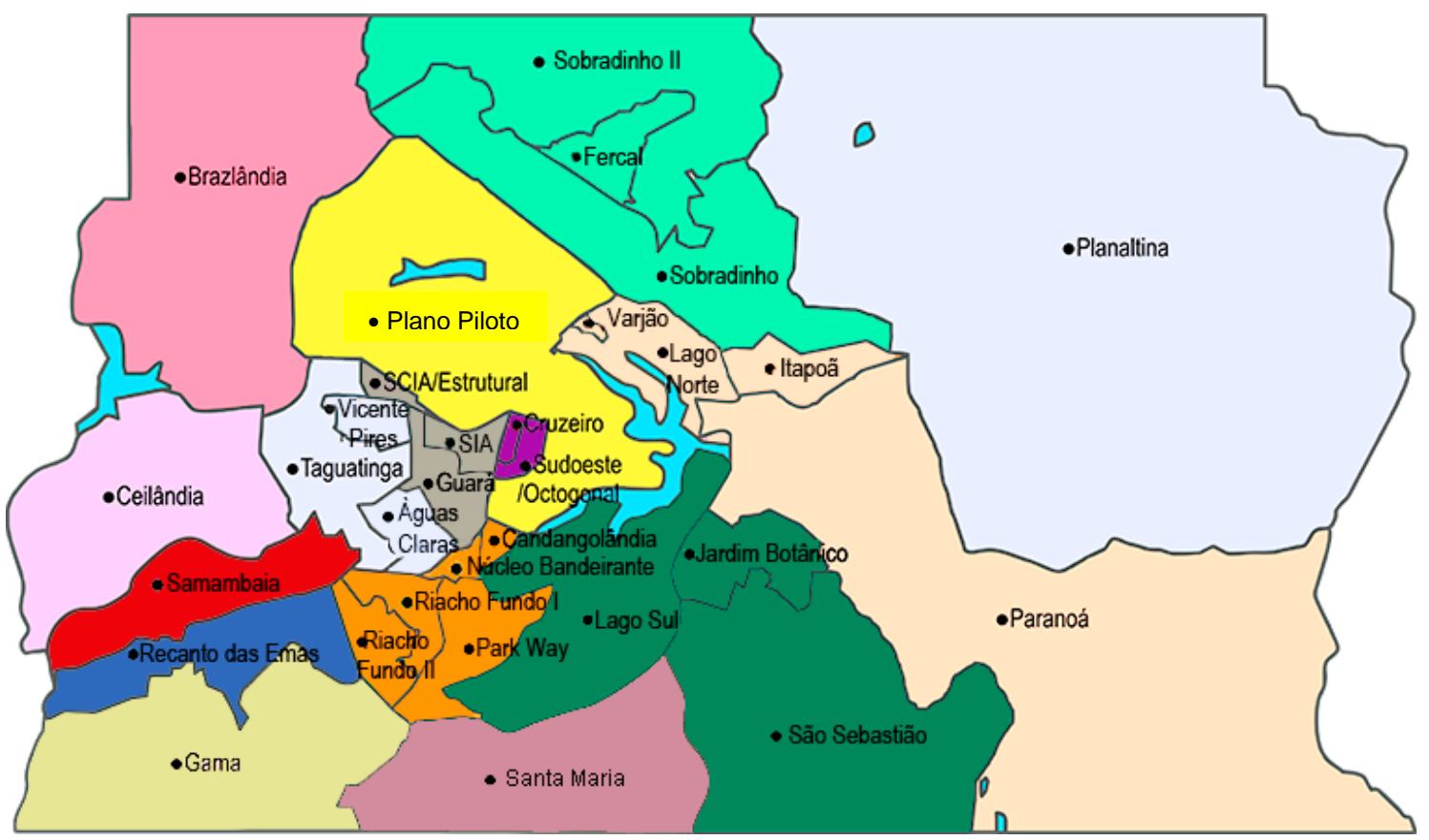

Disponível em: http://www.tre-df.jus.br/eleitor/zonas-eleitorais/enderecos-e-telefones-mapa-por-zona-eleitoral

O Distrito Federal tem 31 Regiões Administrativas (RA), são elas:

Quadro 5: REGIÕES ADMINISTRATIVAS DO DISTRITO FEDERAL

\begin{tabular}{|c|c|c|c|}
\hline RA I Plano Piloto & RA IX Ceilândia & $\begin{array}{l}\text { RA XVII Riacho Fun- } \\
\text { do }\end{array}$ & $\begin{array}{l}\text { RA XXV SCIA - Se- } \\
\text { tor complementar de } \\
\text { Indústria e Abasteci- } \\
\text { mento (Cidade Estru- } \\
\text { tural e Cidade do Au- } \\
\text { tomóvel }\end{array}$ \\
\hline RA II Gama & RA X Guará & RA XVIII Lago Norte & RA XVI Sobradinho II \\
\hline RA III Taguatinga & RA XI Cruzeiro & $\begin{array}{l}\text { RA XIX Candango- } \\
\text { lândia }\end{array}$ & $\begin{array}{l}\text { RA XXVII Jardim Bo- } \\
\text { tânico }\end{array}$ \\
\hline RA IV Brazlândia & RA XII Samambaia & RA XX Águas Claras & RA XXVIII Itapoã \\
\hline RA V Sobradinho & RA XIII Santa Maria & $\begin{array}{l}\text { RA XXI Riacho } \\
\text { Fundo II }\end{array}$ & $\begin{array}{l}\text { RA XXIX SIA - Setor } \\
\text { de Indústria e Abaste- } \\
\text { cimento }\end{array}$ \\
\hline RA VI Planaltina & $\begin{array}{l}\text { RA XIV São Sebasti- } \\
\text { ão }\end{array}$ & $\begin{array}{l}\text { RA XXII Sudoes- } \\
\text { te/Octogonal }\end{array}$ & $\begin{array}{l}\text { RA XXX Vicente Pi- } \\
\text { res }\end{array}$ \\
\hline RA VII Paranoá & $\begin{array}{l}\text { RA XV Recanto das } \\
\text { Emas }\end{array}$ & RA XXIII Varjão & RA XXXI Fercal \\
\hline $\begin{array}{l}\text { RA VIII Núcleo Ban- } \\
\text { deirante }\end{array}$ & RA XVI Lago Sul & RA XXIV Park Way & \\
\hline
\end{tabular}


Há uma controvérsia sobre Brasília se referir a RA I - o Plano Piloto - ou ser sinônimo de Distrito Federal, que é o sentido usado nesta dissertação. Legalmente, a Região Administrativa I foi denominada Brasília entre os anos 1964 e 1997, a partir desta data passou a ser Plano Piloto.

\section{Plano Piloto}

Figura 2: MAPA DO PLANO PILOTO

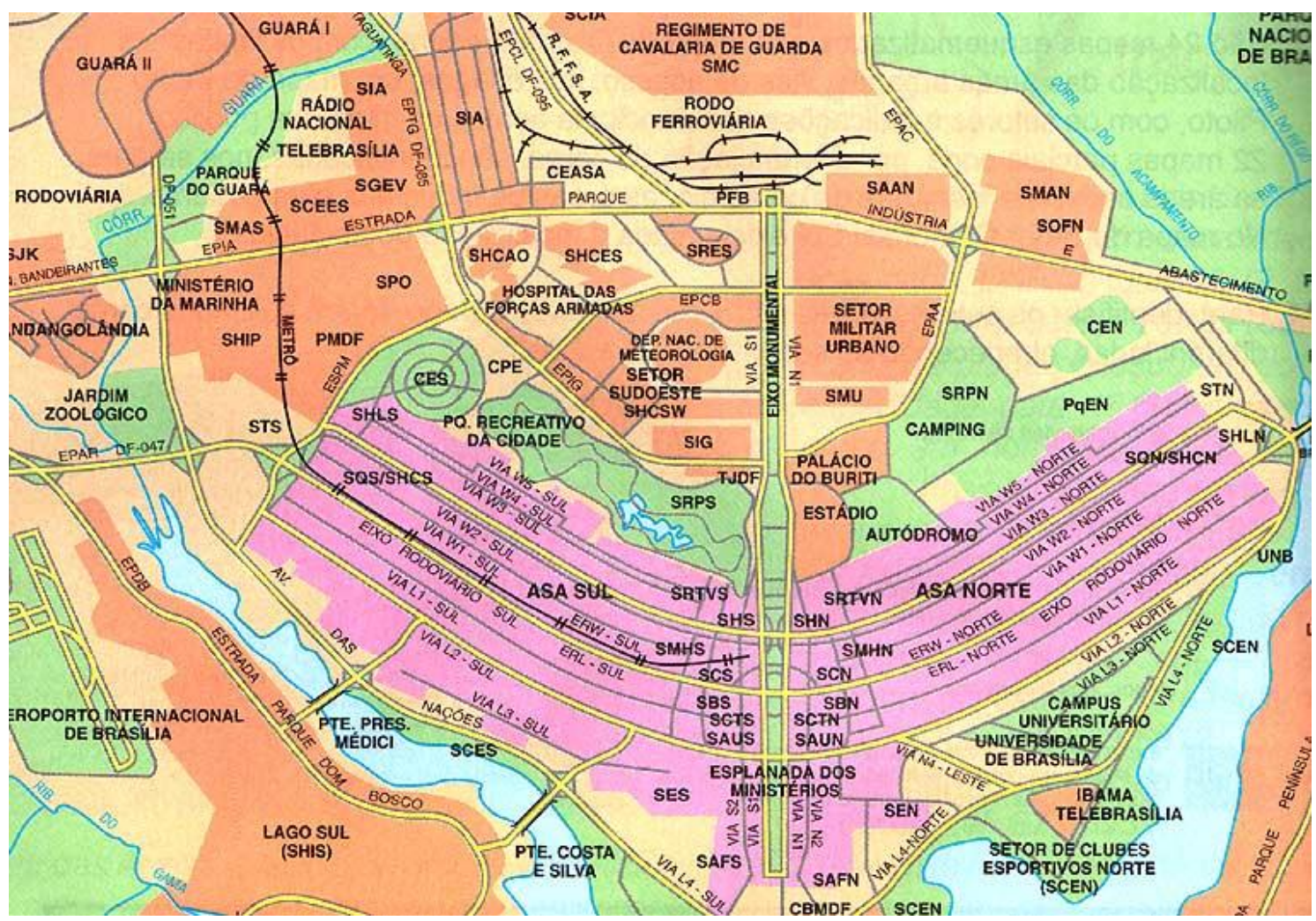

Disponível em: http://doc.brazilia.jor.br/ferrovia-Brasilia/trilhos-mapa-Plano-Piloto-EPIA.shtml

A RA I (Região Administrativa Um de Brasília), legalmente denominada a partir de 1997 de Plano Piloto, é formada pelas Asas Sul e Norte, Setor Militar Urbano (SMU), Setor de Indústrias Gráficas (SIG), Setor Noroeste (entre o Parque Ecológico, o Setor Militar Urbano e a Asa Norte), Vilas Planalto (abaixo do CBMDF, na parte inferior do mapa) e Telebrasília (acima do Lago, entre o Zoológico e a Asa Sul), Granja do Torto e Parque Nacional (extremidade direita superior do mapa). Embora apareçam no mapa, o Sudoeste e a Octogonal formaram uma região administrativa autônima em 2003. 


\section{Região InTEgrada de Desenvolvimento EconôMico do Distrito Fe-}

DERAL E ENTORNO

Figura 3: MAPA DA RIDE-DF

\section{AS CIDADES DO ENTORNO DO DISTRITO FEDERAL}

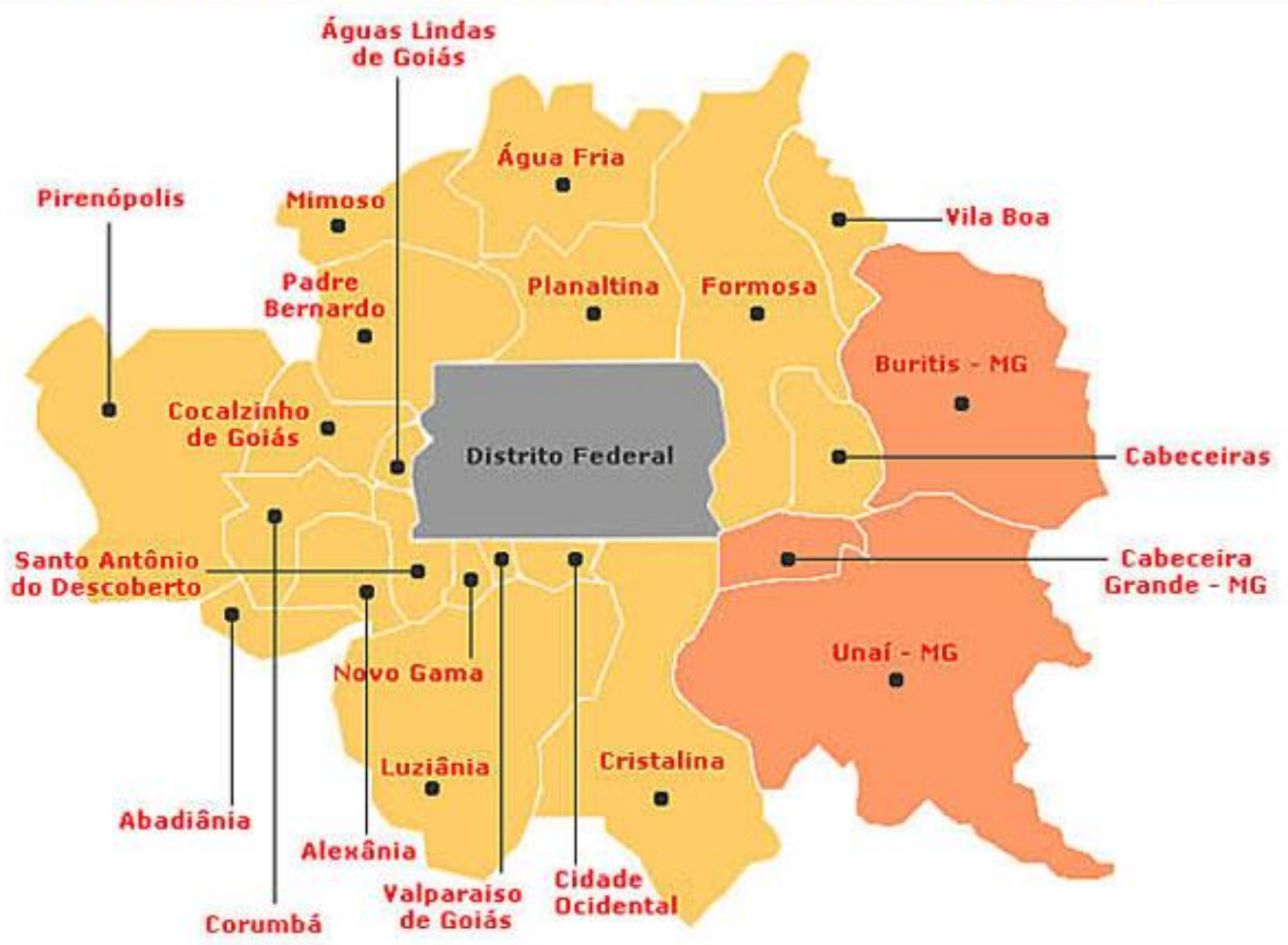

Disponível em: http://klebercaverna.blogspot.com.br/2011/02/brasilia-um-historico-da-capital-do.html

$1 / 2$ 


\section{ANEXo C: A GUERRA dOS NÚMEROS ${ }^{59}$}

FREQUÊNCIA E PORCENTAGENS SEM RESTRIÇÃO RACIAL

\begin{tabular}{|l|r|r|r|r|r|}
\hline todas as mulheres & 2002 & 2005 & 2008 & 2011 & 2014 \\
\hline total de mulheres & 89.694 .597 & 94.247 .103 & 98.537 .099 & 101.834 .312 & 104.771 .572 \\
total mt $^{*}$ & 32.933 .431 & 36.535 .147 & 39.601 .805 & 39.958 .095 & 42.830 .395 \\
total mtd** & 5.732 .376 & 6.174 .957 & 6.255 .512 & 6.244 .254 & 5.972 .833 \\
diaristas & 1.124 .362 & 1.362 .872 & 1.660 .825 & 1.909 .489 & 1.862 .377 \\
mensalistas & 4.608 .014 & 4.811 .468 & 4.594 .687 & 4.334 .765 & 4.110 .456 \\
registradas & 1.414 .613 & 1.551 .365 & 1.614 .912 & 1.832 .796 & 1.806 .961 \\
sem registro & 4.316 .510 & 4.622 .975 & 4.640 .600 & 4.411 .458 & 4.165 .872 \\
contribuintes & 1.545 .833 & 1.709 .726 & 1.827 .805 & 2.180 .358 & 2.365 .551 \\
não-contribuintes & 4.186 .543 & 4.465 .231 & 4.427 .707 & 4.063 .896 & 3.607 .282 \\
internas & 350.561 & 287.042 & 200.609 & 175.141 & 74.102 \\
& & & & &
\end{tabular}

EM RELAÇÃO A 100\% DAS MULHERES TEMOS:

\begin{tabular}{|lr|r|r|r|r|}
\hline todas as mulheres & 2002 & 2005 & 2008 & 2011 & 2014 \\
\hline total $\mathrm{mt}^{*}$ & 36,72 & 38,77 & 40,19 & 39,24 & 40,88 \\
total $\mathrm{mtd}^{* *}$ & 6,39 & 6,55 & 6,35 & 6,13 & 5,70 \\
diaristas & 1,25 & 1,45 & 1,69 & 1,88 & 1,78 \\
mensalistas & 5,14 & 5,11 & 4,66 & 4,26 & 3,92 \\
registradas & 1,58 & 1,65 & 1,64 & 1,80 & 1,72 \\
sem registro & 4,81 & 4,91 & 4,71 & 4,33 & 3,98 \\
contribuintes & 1,72 & 1,81 & 1,85 & 2,14 & 2,26 \\
não-contribuintes & 4,67 & 4,74 & 4,49 & 3,99 & 3,44 \\
internas & 0,39 & 0,30 & 0,20 & 0,17 & 0,07
\end{tabular}

EM RELAÇÃO A 100\% DAS MULHERES NO MERCADO DE TRABALHO TEMOS:

\begin{tabular}{lrrrrrr|}
\hline todas as mulheres & 2002 & 2005 & 2008 & 2011 & 2014 \\
\hline total mtd & *** & 17,41 & 16,90 & 15,80 & 15,63 & 13,95 \\
diaristas & 3,41 & 3,73 & 4,19 & 4,78 & 4,35 \\
mensalistas & 13,99 & 13,17 & 11,60 & 10,85 & 9,60 \\
registradas & 4,30 & 4,25 & 4,08 & 4,59 & 4,22 \\
sem registro & 13,11 & 12,65 & 11,72 & 11,04 & 9,73 \\
contribuintes & 4,69 & 4,68 & 4,62 & 5,46 & 5,52 \\
não-contribuintes & 12,71 & 12,22 & 11,18 & 10,17 & 8,42 \\
internas & 1,06 & 0,79 & 0,51 & 0,44 & 0,17
\end{tabular}

EM RELAÇÃO A 100\% DAS TRABALHADORAS DOMÉSTICAS TEMOS:

\begin{tabular}{|lr|r|r|r|r|}
\hline todas as mulheres & 2002 & 2005 & 2008 & 2011 & 2014 \\
\hline diaristas & 19,61 & 22,07 & 26,55 & 30,58 & 31,18 \\
mensalistas & 80,39 & 77,92 & 73,45 & 69,42 & 68,82 \\
registradas & 24,68 & 25,12 & 25,82 & 29,35 & 30,25 \\
sem registro & 75,30 & 74,87 & 74,18 & 70,65 & 69,75 \\
contribuintes & 26,97 & 27,69 & 29,22 & 34,92 & 39,61 \\
não-contribuintes & 73,03 & 72,31 & 70,78 & 65,08 & 60,39 \\
internas & 6,12 & 4,65 & 3,21 & 2,80 & 1,24
\end{tabular}

"total mt (total de mulheres no mercado de trabalho; ${ }^{* *}$ total mtd (total de mulheres trabalhadoras domésticas).

${ }^{59}$ Números referentes ao Brasil. Fonte: microdados PNAD 2002, 2005, 2008, 2011 e 2014. 
FREQUENNCIA E PORCENTAGENS DE MULHERES BRANCAS

\begin{tabular}{|l|r|r|r|r|r|}
\hline brancas & 2002 & 2005 & 2008 & 2011 & 2014 \\
\hline total de mulheres & 48.691 .197 & 47.791 .813 & 48.792 .999 & 49.934 .379 & 48.831 .530 \\
total $\mathrm{mt}^{*}$ & 18.424 .251 & 19.121 .167 & 20.202 .888 & 20.429 .016 & 20.566 .138 \\
total $\mathrm{mtd}^{* *}$ & 2.503 .321 & 2.480 .246 & 2.399 .059 & 2.398 .100 & 2.081 .133 \\
diaristas & 516.321 & 604.683 & 684.539 & 777.452 & 706.401 \\
mensalistas & 1.987 .000 & 1.875 .563 & 1.714 .520 & 1.620 .648 & 1.374 .732 \\
registradas & 726.070 & 684.777 & 685.812 & 798.095 & 698.046 \\
sem registro & 1.776 .625 & 1.795 .469 & 1.713 .247 & 1.600 .005 & 1.383 .087 \\
contribuintes & 799.022 & 766.329 & 798.201 & 972.469 & 957.662 \\
não-contribuintes & 1.704 .299 & 1.713 .917 & 1.600 .858 & 1.425 .631 & 1.123 .471 \\
internas & 128.425 & 94.677 & 53.195 & 60.530 & 17.528
\end{tabular}

EM RELAÇÃO A 100\% DAS MULHERES TEMOS:

\begin{tabular}{|lr|r|r|r|r|}
\hline brancas & 2002 & 2005 & 2008 & 2011 & 2014 \\
\hline total $\mathrm{mt}^{*}$ & 37,84 & 40,01 & 41,41 & 40,91 & 42,12 \\
total $\mathrm{mtd}^{* *}$ & 5,14 & 5,19 & 4,92 & 4,80 & 4,26 \\
diaristas & 1,06 & 1,27 & 1,40 & 1,56 & 1,45 \\
mensalistas & 4,08 & 3,92 & 3,51 & 3,25 & 2,82 \\
registradas & 1,49 & 1,43 & 1,41 & 1,60 & 1,43 \\
sem registro & 3,65 & 3,76 & 3,51 & 3,20 & 2,83 \\
contribuintes & 1,64 & 1,60 & 1,64 & 1,95 & 1,96 \\
não-contribuintes & 3,50 & 3,59 & 3,28 & 2,86 & 2,30 \\
internas & 0,26 & 0,20 & 0,11 & 0,12 & 0,04
\end{tabular}

EM RELAÇÃO A 100\% DAS MULHERES NO MERCADO DE TRABALHO TEMOS:

\begin{tabular}{lr|r|r|r|r|}
\hline brancas & 2002 & 2005 & 2008 & 2011 & 2014 \\
\hline total mtd * $^{* *}$ & 13,59 & 12,97 & 11,87 & 11,74 & 10,12 \\
diaristas & 2,80 & 3,16 & 3,39 & 3,81 & 3,43 \\
mensalistas & 10,78 & 9,81 & 8,49 & 7,93 & 6,68 \\
registradas & 3,94 & 3,58 & 3,39 & 3,91 & 3,39 \\
sem registro & 9,64 & 9,39 & 8,48 & 7,83 & 6,73 \\
contribuintes & 4,34 & 4,01 & 3,95 & 4,76 & 4,66 \\
não-contribuintes & 9,25 & 8,96 & 7,92 & 6,98 & 5,46 \\
internas & 0,70 & 0,50 & 0,26 & 0,30 & 0,09
\end{tabular}

EM RELAÇÃO A 100\% DAS TRABALHADORAS DOMÉSTICAS TEMOS:

\begin{tabular}{|lr|r|r|r|r|}
\hline brancas & 2002 & 2005 & 2008 & 2011 & 2014 \\
\hline diaristas & 20,63 & 24,38 & 28,53 & 32,42 & 33,94 \\
mensalistas & 79,37 & 75,62 & 71,47 & 67,58 & 66,06 \\
registradas & 29,00 & 27,61 & 28,59 & 33,28 & 33,54 \\
sem registro & 70,97 & 72,39 & 71,41 & 66,72 & 66,46 \\
contribuintes & 31,92 & 30,90 & 33,27 & 40,55 & 46,02 \\
não-contribuintes & 68,08 & 69,10 & 66,73 & 59,45 & 53,98 \\
internas & 5,13 & 3,82 & 2,22 & 2,52 & 0,84
\end{tabular}

"total mt (total de mulheres no mercado de trabalho; ${ }^{* *}$ total mtd (total de mulheres trabalhadoras domésticas). 
FREQUÊNCIA E PORCENTAGENS DE MULHERES PRETAS

\begin{tabular}{|lr|r|r|r|r|}
\hline pretas & 2002 & 2005 & 2008 & 2011 & 2014 \\
\hline total de mulheres & 4.875 .122 & 5.726 .958 & 6.586 .809 & 8.080 .146 & 8.707 .882 \\
total mt $^{*}$ & 1.887 .876 & 2.416 .227 & 2.887 .240 & 3.444 .166 & 3.890 .901 \\
total mtd $^{* *}$ & 584.773 & 700.409 & 708.323 & 825.973 & 847.563 \\
diaristas & 123.124 & 161.616 & 195.685 & 269.232 & 264.041 \\
mensalistas & 461.649 & 538.793 & 512.638 & 556.741 & 583.522 \\
registradas & 168.861 & 213.802 & 215.132 & 237.941 & 274.108 \\
sem registro & 415.912 & 486.607 & 493.191 & 588.032 & 573.455 \\
contribuintes & 184.102 & 230.781 & 242.670 & 285.934 & 347.995 \\
não-contribuintes & 400.671 & 469.628 & 465.653 & 540.039 & 499.568 \\
internas & 44.573 & 44.954 & 33.487 & 31.413 & 19.399
\end{tabular}

EM RELAÇÃO A 100\% DAS MULHERES TEMOS:

\begin{tabular}{lrrrrrr}
\hline pretas & 2002 & 2005 & 2008 & 2011 & 2014 \\
\hline total mt* & 38,72 & 42,19 & 43,83 & 42,63 & 44,68 \\
total mtd** & 12,00 & 12,23 & 10,75 & 10,22 & 9,73 \\
diaristas & 2,53 & 2,82 & 2,97 & 3,33 & 3,03 \\
mensalistas & 9,47 & 9,41 & 7,78 & 6,89 & 6,70 \\
registradas & 3,46 & 3,73 & 3,27 & 2,94 & 3,15 \\
sem registro & 8,53 & 8,50 & 7,49 & 7,28 & 6,59 \\
contribuintes & 3,78 & 4,03 & 3,68 & 3,54 & 4,00 \\
não-contribuintes & 8,22 & 8,20 & 7,07 & 6,68 & 5,74 \\
internas & 0,91 & 0,78 & 0,51 & 0,39 & 0,22
\end{tabular}

EM RELAÇÃO A 100\% DAS MULHERES NO MERCADO DE TRABALHO TEMOS:

\begin{tabular}{l|r|r|r|r|r|}
\hline pretas & 2002 & 2005 & 2008 & 2011 & 2014 \\
\hline total mtd & 30,98 & 28,99 & 24,53 & 23,98 & 21,78 \\
diaristas & 6,52 & 6,69 & 6,78 & 7,82 & 6,79 \\
mensalistas & 24,45 & 22,30 & 17,76 & 16,16 & 15,00 \\
registradas & 8,94 & 8,85 & 7,45 & 6,91 & 7,04 \\
sem registro & 22,03 & 20,14 & 17,08 & 17,07 & 14,74 \\
contribuintes & 9,75 & 9,55 & 8,40 & 8,30 & 8,94 \\
não-contribuintes & 21,22 & 19,44 & 16,13 & 15,68 & 12,84 \\
internas & 2,36 & 1,86 & 1,16 & 0,91 & 0,50
\end{tabular}

EM RELAÇÃO A 100\% DAS TRABALHADORAS DOMÉSTICAS TEMOS:

\begin{tabular}{|lr|r|r|r|r|}
\hline pretas & 2002 & 2005 & 2008 & 2011 & 2014 \\
\hline diaristas & 21,06 & 23,07 & 27,63 & 32,60 & 31,15 \\
mensalistas & 78,94 & 76,93 & 72,37 & 67,40 & 68,85 \\
registradas & 28,88 & 30,53 & 30,37 & 28,81 & 32,34 \\
sem registro & 71,12 & 69,47 & 69,63 & 71,19 & 67,66 \\
contribuintes & 31,48 & 32,95 & 34,26 & 34,62 & 41,06 \\
não-contribuintes & 68,52 & 67,05 & 65,74 & 65,38 & 58,94 \\
internas & 7,62 & 6,42 & 4,73 & 3,80 & 2,29
\end{tabular}

"total mt (total de mulheres no mercado de trabalho; ${ }^{* *}$ total mtd (total de mulheres trabalhadoras domésticas). 
FREQUÊNCIA E PORCENTAGENS DE MULHERES PARDAS

\begin{tabular}{|l|r|r|r|r|r|}
\hline pardas & 2002 & 2005 & 2008 & 2011 & 2014 \\
\hline Total de mulheres & 35.548 .832 & 40.070 .924 & 42.188 .151 & 42.811 .798 & 46.262 .581 \\
total mt ${ }^{*}$ & 12.371 .764 & 14.701 .263 & 16.114 .408 & 15.688 .868 & 17.965 .435 \\
total mtd $^{* *}$ & 2.620 .935 & 2.967 .298 & 3.099 .861 & 2.982 .104 & 3.010 .544 \\
diaristas & 480.949 & 590.315 & 767.779 & 852.365 & 877.419 \\
mensalistas & 2.139 .359 & 2.376 .366 & 2.332 .082 & 2.129 .739 & 2.133 .125 \\
registradas & 515.213 & 647.402 & 701.509 & 787.311 & 827.530 \\
sem registro & 2.105 .095 & 2.319 .279 & 2.398 .352 & 2.194 .793 & 2.183 .014 \\
contribuintes & 561.618 & 712.303 & 779.786 & 919.411 & 1.060 .908 \\
não-contribuintes & 2.059 .317 & 2.254 .995 & 2.320 .075 & 2.062 .693 & 1.949 .636 \\
internas & 175.381 & 145.236 & 110.092 & 81.671 & 35.981
\end{tabular}

EM RELAÇÃO A 100\% DAS MULHERES TEMOS:

\begin{tabular}{lrrrrrr|}
\hline pardas & 2002 & 2005 & 2008 & 2011 & 2014 \\
\hline total $\mathrm{mt}^{*}$ & 34,80 & 36,69 & 38,20 & 36,65 & 38,83 \\
total $\mathrm{mtd}^{* *}$ & 7,37 & 7,41 & 7,35 & 6,97 & 6,51 \\
diaristas & 1,35 & 1,47 & 1,82 & 1,99 & 1,90 \\
mensalistas & 6,02 & 5,93 & 5,53 & 4,97 & 4,61 \\
registradas & 1,45 & 1,62 & 1,66 & 1,84 & 1,79 \\
sem registro & 5,92 & 5,79 & 5,68 & 5,13 & 4,72 \\
contribuintes & 1,58 & 1,78 & 1,85 & 2,15 & 2,29 \\
não-contribuintes & 5,79 & 5,63 & 5,50 & 4,82 & 4,21 \\
internas & 0,49 & 0,36 & 0,26 & 0,19 & 0,08
\end{tabular}

EM RELAÇÃO A 100\% DAS MULHERES NO MERCADO DE TRABALHO TEMOS:

\begin{tabular}{lr|r|r|r|r|}
\hline pardas & 2002 & 2005 & 2008 & 2011 & 2014 \\
\hline total mtd* & 21,18 & 20,18 & 19,24 & 19,01 & 16,76 \\
diaristas & 3,89 & 4,02 & 4,76 & 5,43 & 4,88 \\
mensalistas & 17,29 & 16,16 & 14,47 & 13,57 & 11,87 \\
registradas & 4,16 & 4,40 & 4,35 & 5,02 & 4,61 \\
sem registro & 17,02 & 15,78 & 14,88 & 13,99 & 12,15 \\
contribuintes & 4,54 & 4,85 & 4,84 & 5,86 & 5,91 \\
não-contribuintes & 16,65 & 15,34 & 14,40 & 13,15 & 10,85 \\
internas & 1,42 & 0,99 & 0,68 & 0,52 & 0,20
\end{tabular}

EM RELAÇÃO A 100\% DAS TRABALHADORAS DOMÉSTICAS TEMOS:

\begin{tabular}{|lr|r|r|r|r|}
\hline pardas & 2002 & 2005 & 2008 & 2011 & 2014 \\
\hline diaristas & 18,35 & 19,89 & 24,77 & 28,58 & 29,14 \\
mensalistas & 81,63 & 80,09 & 75,23 & 71,42 & 70,86 \\
registradas & 19,66 & 21,82 & 22,63 & 26,40 & 27,49 \\
sem registro & 80,32 & 78,16 & 77,37 & 73,60 & 72,51 \\
contribuintes & 21,43 & 24,01 & 25,16 & 30,83 & 35,24 \\
não-contribuintes & 78,57 & 75,99 & 74,84 & 69,17 & 64,76 \\
internas & 6,69 & 4,89 & 3,55 & 2,74 & 1,20
\end{tabular}

"total mt (total de mulheres no mercado de trabalho; ${ }^{* *}$ total mtd (total de mulheres trabalhadoras domésticas). 